Materials and Components Technology Division Materials and Components Technology Division Materials and Components Technology Division

\section{Detection and Location of Leaks in District Heating Steam Systems: Survey and Review of Current Technology and Practices}

by D. S. Kupperman, A. C. Raptis, and R. L. Lanham 
Argonne National Laboratory, with facilities in the states of Illinois and Idaho, is owned by the United States government, and operated by The University of Chicago under the provisions of a contract with the Department of Energy.

\section{DISCLAIMER}

This report was prepared as an account of work sponsored by an agency of the United States Government. Neither the United States (iovernment nor any agency thereof, nor any of their employees, makess any warranty, express or implied, or assumes any legal liability or responsibility for the aceuracy, completeness, or usefulness of any information, apparatus, product, or process disclosed, or represents that its use would not infringe privalely owned rights. Reference herein 10 any specific commercial product, process, or service by trade name, trademark, manufacturer, or otherwise, does not necessarily constitute or imply its endorsement, recommendation, or favoring by the United States Government or any agency thereof. The views and opinions of atuthors expressed herein do not necessarily state or reflect those of the United States Government or any agency thereot.

Reproduced from the best alvailathie copy.

Avialable to DOE and bOE contaletors from the

office af Scientilic and ferhnical Information P.O. $130 \times 62$

()ik Ridge, TN 378.31

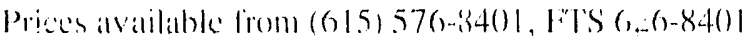

Available wh the public firom the

Nallimal fechnical molomatlion Service

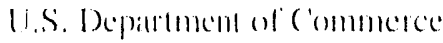

5285 P'ort Royall Roild

Springlicld, VA 22161 
ARGONNE NATIONAL LABORATORY

9700 South Cass Avenue, Argonne, Illinois 60439

\begin{tabular}{ll}
\hline ANL-92/5 & ANL-92/5 \\
& DE92 013740
\end{tabular}

\title{
Detection and Location of Leaks in District Heating Steam Systems: Survey and Review of Current Technology and Practices
}

\author{
by \\ D. S. Kupperman, A. C. Raptis, \\ and R. N. Lanham \\ Materials and Components Techrology Division
}

March 1992

Work supported by the

U.S. DEPARTMENT OF ENERGY.

Assistant Secretary for Conservation and Renewable Energy. Utilities Systems Division 


\section{Contents}

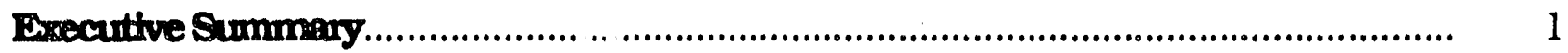

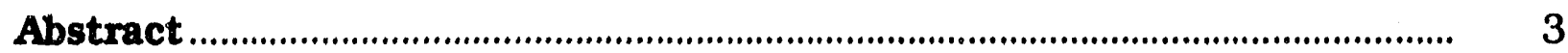

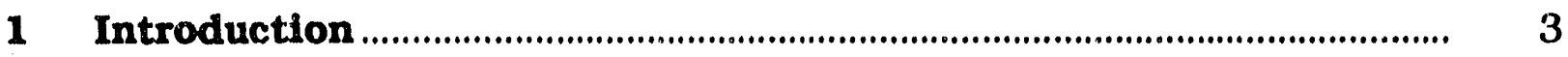

2 Background ..................................................................................................... 4

2.1 Existing Techniques for Leak Detection and Location .............. 5

2.1.1 Acoustic Emission................................................................... 5

2.1.2 Infrared Spectroscopy ............................................................... 6

2.1.3 Tracer Gas.......................................................................... 7

2.1.4 Electrical ...................................................................... 8

2.1.5 Summary of Existing Techniques..................................... 8

2.2 In-Stream Acoustic Monitoring of Leaks ........................................... 9

3 Review of Literature Related to Acoustic Lear Detection in

District Feating Systems ..................................................................................... 10

4 Survey of District Heating Leak Detection and

Location Practices .

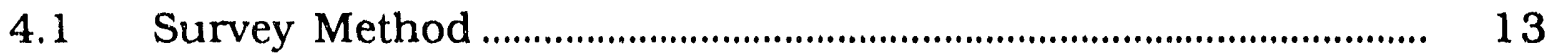

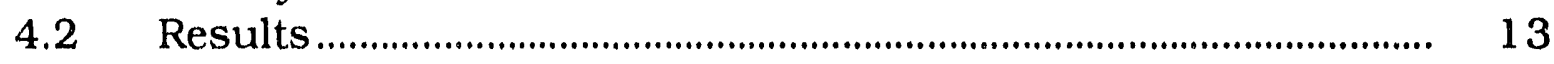

4.2.1 Leak Detection Practices ................................................... 20

4.2.2 Interest in ANL Acoustic Technology ............................... 26

4.2.3 European Experience........................................................... $\quad 30$

4.3 Conclusions from Survey ............................................................. 33

5 Acoustic Leak Location by Cross-Correlation Analysis .......................... 35

5.1 Leak Location with a Commercially Available

Correlator at the ANL Steam Leak Facility.................................... 36

5.2 Leak Location with a Commercially Available Correlator under Field Conditions ...................................................... 36

5.3 Leak Location with a Research-Quality Correlator under Laboratory and Field Conditions ........................................ 38

5.4 Leak Location with an In-Stream Sensor ..................................... 38

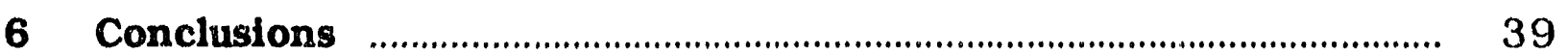

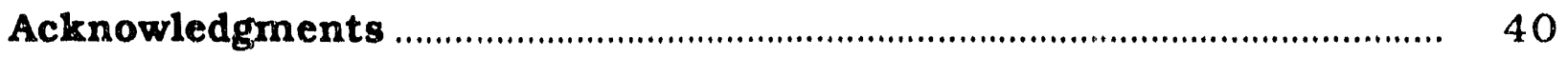

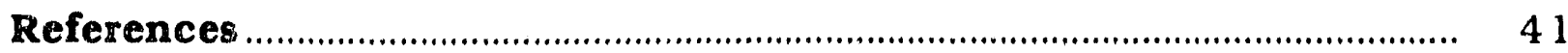


Appendix A: Survey Form and Introductory Remarks for Acoustic

Leak Detection and Location...................................................... 43

Appendix B: Notes from Survey .................................................................. 49

Figures

$1 \quad$ Basic Piping Designs ............................................................................... 19

Tables

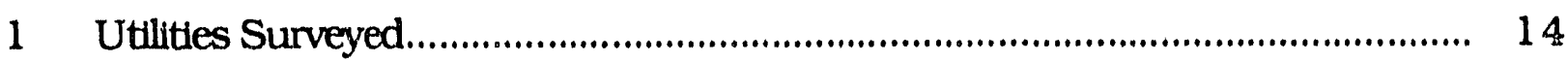

2 Basic System Data ...................................................................................... 15

3 Summary of Pipe Installations and Expansion Devices...................... 17

4 Other System Details ................................................................................... 18

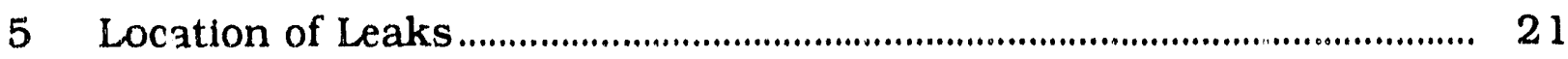

6 Leak Detection Methods .......................................................................... 22

$7 \quad$ Leak Location Methods................................................................................... 23

8 General Interest in ANL Technology .................................................... 27

9 Specific Interest in ANL Technology ........................................................... 31 


\title{
Detection and Location of Lealss in District Heating Steam Systems: Survey and Revlew of Current Technology and Practices
}

\author{
by
}

D. S. Kupperman, A. C. Raptis, and R. N. Lanham

\section{Executive Summary}

This report presents the results of a survey undertaken to identify and characterize current practices for detecting and locating leaks in district heating (DH) systerns, in particular steam systems. Currently used technology and practices are also reviewed. In addition, the survey was used to gather information of potential importance in the application of acoustic leak detection. Discussion is included of a few examples of attempts to locate leaks in steam and hot water pipes by correlation of acoustic signals generated by the leaks.

Several leak detection techniques are currently avallable. The application and effectiveness of each technique depend on the design and installation method of the DH piping, location of the leak (in the jacket or the carrier pipe), system operating parameters, and knowledge of system layout and components. The most common systems used today are classified according to their principle of operation, i.e., acoustic emission. infrared spectroscopy, tracer gas, and electrical.

Acoustic leak detection is potentially the most effective method for locating leaks. However, sensors placed directly on the pipe outer wall may not be effective enough to locate steam leaks by acoustic techniques in long runs of $\mathrm{DH}$ piping. One way to circumvent the general problem of steam leak detection in buried pipe is to insert an acoustic transducer inside the pipe to directly detect steam-propagated sound waves. This concept is the focus of a program at Argonne National Laboratory (ANL) cofunded by Consolidated Edison of New York and NRG Thermal (a subsidary of Northern States Power).

The cor clusions from the survey are presented below. 
1. The extent to which leak detection is considered important varies significantly from utility to utility. At least three of the larger utilities spend $\$ 1$ million or more each year locating and repairing leaks. One-half of the respondents do not consider leaks to be a problem and/or are satisfied with current leak location methods.

2. The most common leak location method is to feel the pavement to determine hot spots and/or to focus on specific trouble-spot components using as-built drawings.

3. Almost one-quarter (23\%) of the respondents have found an acoustic technology useful to some extent in leak location, while $18 \%$ have tried an acoustic technology withour success. The effectiveness of various acoustic or vibration-sensing devices appears to depend on several factors, including the device used, staff expertise and experience, soil type, and pipe depth. One-half of the respondents who indicated that they found an existing acoustic technology useful also stated that they are interested in the ANL technology because they feel that current methods are not as effective as the respondents would like.

4. Most utilities are reluctant to do hot taps, and this presents a significant potential harrier to the use of the proposed ANL leak detection and location technology. (In a hot tap, a valve is attached to the pipe and a microphone is inserted through the valve. The microphone need not i main in the pipe because the valve permits removal of the microphone and isolation of the insertion hole.) Concern about hot taps appears to be based on prior exrerience with large (several-inch) hot taps. However, the microphone under development at ANL will employ a much smaller tap and may relieve much of the present concern. 
Abstract

This report presents the results of a survey undertaken to identify and characterize current practices for detecting and locating leaks in district heating systems, particular steam systems. Currently used technology and practices are reviewed. In addition, the survey was used to gather information that may be important for the application of acoustic leak detection. A few examples of attempts to locate leaks in steam and hot water pipes by correlation of acoustic signals generated by the leaks are also discussed.

\section{$1 \quad$ Introduction}

The cost of building and maintaining thermal distribution systems contributes substantially to the cost of energy delivered to end users. To improve the competitiveness of existing DH systems, the capital, operating, and maintenance costs must be reduced. Thermal-distribution piping systems installed underground in densely populated areas are subject to a variety of internal and external conditions that reduce their performance. In particular, pipe leaks are a major ca'ise of energy loss and maintenance cost over the life of a DH system. To minimize these losses and costs, leaks must be detected, located, and repaired promptly.

This report presents the results of a survey undertaken to identify and characterize current practices for detecting and locating leaks in district heating systems, in particular steam systems. The sur fy was used to gather information on (a) characteristics of the distribution system that may be important for acoustic leak detection, (b) currently used technology and practices, and (c) possible interest in acoustic leak detection technology such as that under development at Argonne National Laboratory (ANL). In addition, a review of leak detection technology and available literature on acoustic leak detection is presented. A few examples of attempts to locate leaks in steam and hot water pipes by correlation of acoustic signals generated by the leaks are discussed. 
Leak detection and location techniques are currently available for several configurations of heat distribution systems carrying water. 1 The performance of these techniques has not been well documented by the industry. Most of the existing data are in the possession of individual system operators and have not been collected and disseminated to the industry. In this report, the results of a survey of utilities is presented, eliminating this previous gap in information. Until now, the only readily avallable data on leak detection techniques and their application and performance are those documented by an evaluation study conducted by the Construction Engineering Research Laboratory (CERL) of the U.S. Army Corps of Engineers. ${ }^{2}$ The conclusions of the CERL study were that every available leak-detection technique is limited in application to a specific conduit configuration and installation technique. With regard to acoustic leak detection in particular, several researchers have investigated the application of acoustic leak detection to other systems, including nuclear reactors, with some success. ${ }^{3-7}$

The major elements of an underground thermal distribution system are distribution piping, thermal insulation, pipe supports, anchors, expansion/contraction devices, conduit/envelope structures, protective outer coverings, joint sealants, external drains, and manholes. Among the factors that influence the design, materials selection, and installation methods for thermal distribution systems are initial cost, service life, maintenance costs, thermal and economic efficiency, and safety. In the past, performance improvements in thermal distribution systems have been minor.

Undergr ound piping systems are installed and operated in very harsh environments and their long-term reliability is highly dependent on corrosion protection, installation technique, site hydrology, and proper maintenance. After a few years of operation, most underground piping systems are likely to incur leaks in the carrier pipe. If not detected and repaired promptly, these leaks can cause major damage to a whole section of a piping system and neighboring utilities, as well as substantial energy losses. Most of the historical data on the causes of piping leaks in the United States have been derived from steam distribution facilities of the federal government. These data indicate that leaks in underground piping systems are often caused by corrosion, mechanical rupture due to soil 
subsidence and pipe expansion, or construction deficiencies. In a study conducted by a Swedish national laboratory on the fallure of Swedish DH hot-water distribution pipes from 1968 to 1982, several key causes of pipe leaks were identified. 1

Although steam leaks in underground pipes of DH systems may not have the safety significance of a leak in a nuclear reactor, they can be hazardous to the public and costly in terms of energy loss. In St. Paul, Minnesota, for example, one energy system lost $50 \%$ of its steam output through leakage before the system was repaired. The U.S. Department of Defense maintains about 6000 milles of heat distribution lines, mainly underground, and energy loss has become a concern. ${ }^{2}$ A reliable leak detection and location system for underground piping could reduce the costs of operating a DH system and minimize the general liability of the company providing the service. However, the task of finding leaks is complex because of the configuration of the distribution systems. Insulated heat-carrying pipe, for example, can be supported inside a protective buried conduit with an air space between the pipe insulation and the conduit's inner wall. Supply and return lines can be in common or separate conduits. Alternatively, a concrete trench with removable covers can contain insulated supply and return lines.

\subsection{Existing Techniques for Leak Detection and Location}

Various leak detection techniques are currently avallable. The application and effectiveness of each technique depend on the design and installation method of the DH piping, location of the leak (in the jacket or the carrier pipe), system operating parameters, and knowledge of system layout and components. The most common systems today are classified according to principle of operation as follows: acoustic einission, infrared spectroscopy, tracer gas, and electrical.

\subsubsection{Acoustic Emission}

When a leak occurs in a pipe carrying pressurized hot water or steam, the turbulent flow of the fluid passing through the crack or hole generates sound waves. These waves are omnidirectional and their intensity decreases inversely with distance from the leak. Commercially available acoustic leak detection and location systems incorporate acoustic sensors to detect and measure the intensity of the noise signal generated by a leak. Acoustic 
signals can be detected by placing a sensing microphone in direct contact with a carrier pipe at an accessible point. This method is more effective for water-filled pipe because the sound in the water is coupled to the pipe wall due to the relatively small difference in acoustic impedances. For a steam-filled pipe, the acoustic impedance mismatch is much greater and the sound propagating in the steam is not transferred readily to the pipe wall; thus, sensors that detect leak noise by being placed on the pipe wall would be less efficient than a sensor that could be inserted into the pipe.

Another approach to measuring the intensity of the acoustic leak signal is bar-holing, in which a metal rod is driven into the ground to establish metal-to-metal contact with the carrier pipe. The metal rod acts as a waveguide and the acoustic signal is measured at the upper end of the rod. To locate the leak, multiple acoustic wave measurements are taken. The location is then found by comparing the measured intensities of the leak signal at various locations and identifying the point where it is highest. Another method is to move a microphone, in contact with the ground, along a path following the pipe and use the maximum-amplitude noise signal to locate a leak. The success of this method depends on the skill of the operator and the configuration of the underground piping.

A more sophisticated and potentially cost-effective acoustic leak detection/location technique requires only two measurements of the leak-noise signal and uses an advanced computerized system to analyze the signals and locate the leak via a cross-correlation function. This function is a mathematical concept that can be be represented by a graph that plots amplitude over time. In the absence of a leak, the graph is generally a series of small bumps caused by background noise. The appearance of a large peak indicates a leak. Time (how long it takes the signal to travel from the source to one of the two sensors) is easily converted to distance. By comparing the time delays in signals received by the two sensors, we can accurately pinpoint the leak.

\subsubsection{Infrared Spectroscopy}

A leaking steam pipe could increase the temperature of the ground and surface area above the leak. If the ambient temperature, depth of the leaking pipe, and variations in ground-surface temperature are within certain limits, leaks can be detected by infrared spectroscopy. A temperature profile of the surface above the pipeline, taken with a camera 
mounted on a motor vehicle or helicopter, is compared to a reference temperature proflle taken when there were no leaks in the pipeline. Also, temperature-reading devices can be used to identify variations in ground temperature arid hot spots on the ground surface along the pipeline route. Hot spots identified by infrared spectroscopy are likely to be the locations of pipe leaks.

Infrared spectroscopy is most effective when a leak occurs in both the carrier pipe and its jacket at the same location. Soll condition, pipe system design, installation technique, and leak type are critical factors in the application and effectiveness of this method. With certain ground soil conditions and installation techniques, leaking hot water may spread into the surrounding soll and blur the ieak source or it may be absorbed by the soil and limit the effectiveness of the method. Accuracy is also limited when a leak occurs only in the carrier pipe or the jacket, and when there are multiple leaks in the pipe system. In general, this method is not applicable in many commonly occurring leak situations and it is expensive.

\subsubsection{Tracer Gas}

The tracer gas method can be used to detect and locate leaks in underground heat distribution systems that employ a double wall with an annular space between the carrier and the casirs pipes. Heat distribution based on this pipe design is found mostly in federal government installations. Leaks can be detected and located in both the carrier and casing pipes. Gas is injected into the pipe system and its concentration is measured at the surface or in shallow bar-holes made at intervels about equal to the average depth of the conduit along the entire length of the pipe system. The hole with the highest gas concentration will usually indicate the location of the leak. Sulfur hexafluoride $\left(\mathrm{SF}_{6}\right)$ is the most frequently used tracer gas $k$ a ause it does not occur naturally. Although this technique is feasible for detecting leaks in double-walled piping systems, it is not widely used. A major disadvantage is the need to shut down the heat distribution system when the carrier pipe is tested. Calculations to determine diffusion time and leak location are often difficult. In testing for casing leaks, a scan of the surface to detect the tracer gas and locate the leak is not always reliable because, depending on soil conditions, the leaking gas may either travel vertically or follow the path of least resistance. 


\subsubsection{Electrical}

Most of the recently built DH hot water piping systems in the United States and Europe have factory-made insulated pipes that incorporate electrical devices for detecting and locating leaks. To detect leaks in the carrier pipe and casing, an exposed wire is installed in the pipe insulation; the electrical resistance between this electrical conducior and the metal carrier pipe can then be measured and monitored. Leaks can be detected by comparing the measured resistance with a minimum reference value. Another electrical method for locatirig leaks is based on time-domain reflectometry. When th. outer braid of a coaxial cable, installed in the pipe insulation, is infiltrated by a leaking fluid (groundwater from a leak in the casing or hot water from a carrier pipe leak), it undergoes a change in characteristic impedance at the leak. This change converts outgoing electrical signals 'rom the plant into reflected pulses or standing waves. To locate the leak, the signals are detected and analyzed at the plant with signal-processing equipment.

The currently available electrical techniques for detecting and locating leaks are used with preinsulated pipe systems. These techniques have only been used in the last 10-15 years in hot-water piping systems, and existing heat distribution installations cannot be retrofitted cost-effectively. The long-term reliability of electrical techniques has not been proved.

Corrosion, the most common problem with underground piping systems, is likely to limit the life of the signal wires and reduce the long-term effectiveness of this system.

\subsubsection{Summary of Existing Techniques}

All of the commonly used leak detection techniques have limitations. The infrared method is limited by high cost and "blurring" of the hot spot as heated water spreads into the surroundings or is directed away from the source of the leak. Accuracy of the tracer gas method is limited by variations in gas diffusion rates and preferential migration. Another disadvantage of the tracer gas method is that the DH system must be shut down when the pipes are tested. Electrical methods pose reliability problems and cannot be used in olcier systems. The acoustic method, though somewhat of an "art" in practice, currently has the greatest potential for detecting leaks in underground pipes. ${ }^{2}$ 


\subsection{In-Stream Acoustic Monitoring of Leaks}

Transducers or transducer/waveguide systems placed directly on the pipe outer wall may not be effective enough to locate leaks acoustically in long runs of $\mathrm{DH}$ piping. Two factors contribute to the problem with steam-filled pipes. The first is that acoustic impedance mismatch between the pipe wall and the steam is so great that the amount of sound energy coupled into the pipe from the steam is limited. (Sound traveling inside a water-filled pipe is efficiently coupled to the pipe wail and can be detected by externally mounted transducers.) The effectiveness of cross-correlation analysis for leak location in steam-filled pipes is further reduced by the numerous modes of acoustic wave propagation present in the pipe wall. These modes are not normally present in water-filled pipes because of the damping effect of the water.

One way to circumvent the general problem of steam leak detection in buried pipe is to insert an acoustic transducer inside the pipe for direct detection of steam-propagated sound waves. We briefly evaluated a capacitance-microphone-type transducer (Knowles Electronics, Inc., Model BT-1834) that can be inserted into a pipe through a small hole. The transducer was inserted into the ANL test pipe through a hole used for artificial leaks. An Endevco $2224 \mathrm{C}$ accelerometer was placed on the outer wall of the pipe at the same location. The pipe was filled with gas at $=6$ psi pressure. The transducer showed superior signal-to-noise ratios over most of the examined frequency range. 1 For example, near $4 \mathrm{kHz}$, the signal-to-noise ratio for the capacitance microphone transducer is about 10 $\mathrm{dB}$ higher than for the accelerometer. This advantage is reduced by a fer decibels at higher frequencies (e.g., $10-12 \mathrm{kHz}$ ). Cross-correlation analysis of signals from a gas leak also suggests that these small transducers can be significantly more effective than transducers mounted on the outside of the pipe. A well-defined correlation peak for a leak could not be obtained with externally mounted accelerometers, whereas it could be with in-stream transducers.

A potential problem with this concept is that, for continuous monitoring, the transducer must be protected from the erosive and corrosive effects of the fluid stream, as vell as from the elevated temperatures. Furthermore, the sensor must be inserted so that the fluid does not create high levels of acoustic noise as it flows past the sensor. These problems can be overcome, and the advantage of not having to analyze 
propagation modes in the pipe wall makes the pursuit of an intrusive sensor particularly attractive for correlation analysis. A goal of the current program at ANL is the development of an in-stream acoustic sensor for steam leak location.

\section{Review of Literature Related to Acoustic Leak Detection in District Heating Systems}

Several papers on the detection and location of leaks are briefly reviewed below. In general, attempts to locate leaks acoustically have concentrated primarily on water filled pipes. No papers dedicated to detection and location of stear leaks have been found. In general, location of leaks in water-filled pipes have been successful. Other references are presented at the end of this report

Ref. 8 "Acoustic leak location in district heating pipes."

Fuchs, H.V., Frommhold, W., Poggemann, R., and Zenker, P. (Correlation analysis)

Source: HLH, Heizung, Lüftung, Klimatechnik, Haustechnik, v. 42:1; Fraunhofer-Institut fi.r Bauphysik, Stuttgart ${ }_{r}$ and Energieversorgung Oberhausen AG (West Germany),

Language: German

Leaks were found using LOKAL ("leak location through correlation analysis"). Only water leaks were detected. Leaks were detected with frequencies less than $1 \mathrm{kHz}$ and sensors placed on the pipe outer wall. Location was by cross-correlation analysis. Leak rates of 0.05 to $3.5 \mathrm{~m} 3 / \mathrm{hr}$. were detected at distances up to $260 \mathrm{~m}$.

Ref. 9 "Computer-aided measuring system for automatic monitoring of pipe networks and leak detection." Schwarze, H.

(Noise-correlation technique)

Source: Technisches Messen, v. 55, no. 7-8, 1988, pp. 279-285;

Fachhochschule Bielfeld, Bielfeld, West Germany.

Language: German

Location of pipe leaks is determined by employing an LSI chip TDC1028 and three radio links to calculate the cross-correlation function. This work involves detection of water leaks only. The 
frequencies of interest are $20 \mathrm{~Hz}$ to $10 \mathrm{kHz}$. Microphones are attached to hydrants. Electronic filters provide flexibility in selection. of frequencles $(100 \mathrm{~Hz}$ to $5 \mathrm{kHz}$ ).

Ref. 10 "Leakage monitoring in synthetic jacket pipes for district heating supply." Micheel, H. J. (Impulse echo measurement)

Source: Fernwarme International, v. 16, no. 6, Nov.-Dec. 1987, pp. 380-385;

Salzgitter Elektronik GmbH, Kiel, West Germany. Language: German

With a network of moisture indicators and wire leads, the location of leaks is determined by insulation resistance measurement and impulse echo measurement.

Ref. 11 "Environmental monitoring technologies". Chang, D. B., Pierce, B. M., and Shih. I. Source: SAE Technical Paper Series 910190, International Congress and Exposition, Detroit, Michigan, Feb. 25March 1, 1991

Language: English

This paper discusses a fiber-optic liquid level sensor that may provide an accurate measurement of leakage from underground storage tanks. Leaks are detected by measuring the change in light intensity transmitted along a special fiber-optic cable. When the cable is in contact with the liquid (as it could be if it were burled and in contact with a leaking fluid), the transmitted light is attenuated.

Ref. 12 "Leak location in district heating networks using acoustical correlation techniques." Turtiainen, $\mathrm{H}$. (Acoustic correlation techniques)

Source: Valtion Teknillinen Tutkimuskeskus, Espoo, Finland. Language: Finnish

The theoretical and applied sides of leak location through acoustic correlation are based on experience with 17 real leaks.

Ref. 13 "In situ control of district heating networks." Gransell, H. and Ljungquist, John.

(Damage analysis and on-site measurements) 
Source: Annual Conference of the Int'l District Heating Assn., v. 76; Studsvik Energiteknik AB, Language: English

Reports on damage analysis and on-site measurements, and describes methods for leak detection.

Ref. 14 "Active acoustic detection of leaks in underground natural gas distribution lines." Jette, A. N., Morris, M. S.; Murphy, J. C.; and Parker, J. G.

(Field measurements, theoretical elastic waves, optical vibration sensor)

Source: Materials Evaluation, v. 35, no. 10, Oct. 1977, pp. 90-96, 99; Johns Hopkins University, Baltimore, Maryland, USA.

Language: English

Describes research program aimed at understanding the acoustic detection of leaks in pipes.

Ref. 15 "Pipeline leak location using radiotracer technique." Eapen, A.C., Ajmera, R.I .., and Agashe, S.M.

(Radiotracer technique)

Source: Bhabha Atomic Research Centre, Bombay, India - Isotope Div. Language: English

Compares new radiotracer technique to other leak detection techniques.

\section{Survey of District Heating Leak Detection and Location Practices}

This survey was undertaken as part of a joint program between the U.S. Department of Energy and utilities that operate district heating and cooling systems. The objective of the joint program is the development of an in-stream acoustic sensor to locate steam leaks. The survey itself was aimed at identifying and characterizing current practices for detecting and locating leaks in district heating systems, specifically steam systems. This 
information reflects the conditions, needs, and requirements of the $\mathrm{DH}$ industry in developing acoustic leak detection technology

\subsection{Survey Method}

The survey was conducted through telephone contacts with utility members of the International District Heating and Cooling Association (IDHA). Introductory remarks used in the survey, and the form used to record the information obtained, are included in Appendix A.

The survey was designed to gather information in three major areas: (a) characteristics of the distribution system that may be relevant to design and implementation of the acoustic leak detection technology, (b) technologies and practices currently used by the utility to detect and locate leaks, and (c) interest in utilizing the acoustic leak detection technology developed by ANL.

Results of the survey are summarized below, and detailed notes are provided in Appendix B.

\subsection{Results}

There are 59 companies listed as "utility" members of the IDHA. Of these, 3 are European, 4 are Japanese, 5 are planning systems that are not. operational yet, and 3 are holding companies that own a number of operating district heating and cooling systems. All 44 of the operational North American district heating and/or cooling system companies were surveyed. Table 1 shows the names and telephone numbers of the companies and individuals contacted. In addition, investigations of European leak detection practices were made and summarized.

In Table 2, basic system data are summarized. Of the 4.4 companies contacted, 30 provide steam only, 9 provide steam plus chilled water and/or hot water, 2 provide hot water only, and 2 provide hot water and chilled water.

Some of these systems have had pipe in the ground for many years. Of the 31 systems for which age data were given, 17 were at least 60 years old. 
Table 1. Utilities Surveyed

\begin{tabular}{|c|c|c|}
\hline Name of system & Contact person & Phone \\
\hline Alabama Power Company & Dale Dambach & $205-226-1880$ \\
\hline Baltimore Thermal & Brlan Boor & $301-625-2222$ \\
\hline Boston Thermal & Alan Murphy & $617-482-9550$ \\
\hline Central Heat Distribution (Vancouver) & Jim Barnes & $604-688-9584$ \\
\hline Cleveland Thermal & Rick Pucak & $216-241-5980$ \\
\hline Cogeneration Management Company & Don Yeaple & $617-732-2700$ \\
\hline Concord Steam & Mark Saltzman & $603-224-1461$ \\
\hline Consolidated Edison & Tony Codner & $215-576-2440$ \\
\hline Dayton Power and Light & Henry Routzohn & $513-227-2481$ \\
\hline Detroit Edison & Terry Schumaler & $313-237-5290$ \\
\hline District Energy St. Paul & Ray Schmidt & $612-297-8955$ \\
\hline Energy Networks Inc. & Jeff Lindberg & $203-727-3095$ \\
\hline Energy Systems Co. - Omaha & Dave Woods & $402-346-9066$ \\
\hline Eugene Water and Electric Board & Dennis Daggett & $503-484-2411$ \\
\hline Falrbanks Municipal Utilities & John P. Stenberg & $907-459-6259$ \\
\hline Georgla Power Co. & Robert Stewart & $404-526-4678$ \\
\hline Harrisburg Steam Works & Jan Sockel & $717-234-4600$ \\
\hline Indianapolis Power and Light & Fred Brasher & $317-261-8854$ \\
\hline Jamestown Board of Public Utilities & Doug Charrp & $716-483-7582$ \\
\hline Kent County Public Works & Bill Allen & $616-774-3694$ \\
\hline Lansing Board of Power and Light & Joette Woodard-Yauk & $517-371-6780$ \\
\hline Mid-America Energy Resources & Davld Klesel & $317-261-8893$ \\
\hline Minneapolis Energy Center & Gary Gustarson & $612-349-6072$ \\
\hline Nashville Thermal & Roger Beckham & $615-244-3150$ \\
\hline NRG Thermal & Mark Anderson & $612-373-5335$ \\
\hline Pacific Energy/Central Plants Inc. & Vic Dilloway & $213-725-1139$ \\
\hline Pacific Gas and Electric & Rich Mayer & $415-973-3828$ \\
\hline PACT, Ltd. & Bob Sazlo & $412-642-7446$ \\
\hline Philadelphia Thermal & Steve Smith & $215-875-6911$ \\
\hline Pittsburgh Thermal & Jim Curnmings & $412-231-0409$ \\
\hline Public Service Co, of Colorado & Dennis Ellot & $303-573-4397$ \\
\hline Rochester District Heating Cooperative & Howard Cone & $716-546-8890$ \\
\hline St. Louis Thermal & Art Stanze & $314-621-3550$ \\
\hline Seattle Steam & Woody Woodard & $206-623-6366$ \\
\hline Toronto District Heating Corp. & Alex Bystrin & $416-392,-6838$ \\
\hline Trenton District Energy & Don Lelbowitz & $609-396-1892$ \\
\hline Trigen - Tulsa & Ken Adams & $918-582-2212$ \\
\hline Trigen - London, Ontario & Gary Nickerson & $519-434-9194$ \\
\hline Trigen - Kansas City & Bob Stevenson & $816-556-2821$ \\
\hline Trigen - Nassau County & Al Gussler & $609-396-7651$ \\
\hline United Illuminating & Craig Bradley & $203-787-7200$ \\
\hline Willmar Publlc Utilities & Bart Murphy & $612-235-4422$ \\
\hline Wisconsin Electric & Tom Ventmiglia & $414-221-2491$ \\
\hline Youngstown Thermal & Rich Burns & $216-743-7712$ \\
\hline
\end{tabular}


Table 2. Basic System Data

\begin{tabular}{|c|c|c|c|c|}
\hline Name of system & $\begin{array}{l}\text { Max. age } \\
\text { of pipe } \\
(y x)\end{array}$ & $\begin{array}{c}\text { Annual } \\
\text { sales } \\
\left(10^{6} \mathrm{Btu}\right)^{\mathrm{a}}\end{array}$ & $\begin{array}{l}\text { Miles } \\
\text { of } \\
\text { pipe }\end{array}$ & $\begin{array}{c}\text { Services } \\
\text { provided } \\
(\mathrm{S}=\text { stearn; } \\
\mathrm{HW}=\text { hot water } \\
\mathrm{CW}=\text { cooling) }\end{array}$ \\
\hline Alabama Power Company & 70 & 548,522 & 6 & $\mathbf{S}$ \\
\hline Baltimore Thermal & & $1,646,400 \#$ & 15 & $\mathrm{~s}$ \\
\hline Boston Thermal & 60 & & 22 & $\mathbf{S}$ \\
\hline Central Heat Distribution (Vancouver) & 22 & 998,473 & 5 & $\mathrm{~s}$ \\
\hline Cleveland Thermal & & $1,399,648$ \# & 19 & $\mathrm{~s}$ \\
\hline Cogeneration Management Company & 15 & & 1.5 & $S$ \\
\hline Concord Steam & 60 & 300,000 & 8 & $s$ \\
\hline Consolidated Edison & & $37,298,000$ & 100 & $\mathbf{S}$ \\
\hline Dayton Power and Light & 89 & & 15 & $\mathrm{~s}$ \\
\hline Detrolt Edison & 85 & $3,957,353$ & 41 & $\mathbf{S}$ \\
\hline District Energy St. Paul & 8 & 824,557 & 20 & HW \\
\hline Energy Networks Inc. & & $1,003,932$ & 17 & S, HW, CW \\
\hline Energy Systems Co. - Ornaha & 24 & & & S. CW \\
\hline Eugene Water and Electric Board & 80 & $\begin{array}{l}467.881 \# \\
135,360 \#\end{array}$ & 9 & S HW \\
\hline Georgia Power Co.84 & 84 & 107,300 & 28 & $\mathrm{~s}$ \\
\hline Harrisburg Steam Works & & 357.700 & 7 & $\mathrm{~S}$ \\
\hline Indianapolis Power and Light & & $5,681,900$ & & $\mathrm{~S}$ \\
\hline Jamestown Board of Public Utillies & 7 & & 6 & $\mathbf{S}$ \\
\hline Kent County Public Works & 70 & 695,568 & 1.5 & $\mathbf{s}$ \\
\hline Lansing Board of Power and Light & 83 & $1,882,858$ & 12 & $\mathbf{S}$ \\
\hline Mid-America Energy Resources & 1 & & & CW \\
\hline Minneapolis Energy Center & & $1,714,208$ & 4 & S, HW, CW \\
\hline Nashville Thermal & 17 & 398,503 & & S. CW \\
\hline NRG Thermal & 8 & & 5.5 & $\mathrm{~s}$ \\
\hline Paciftc Energy/Central Plants Inc. & & & & $S, H W, C W$ \\
\hline Pacific Gas and Flectric & 80 & 722,646 & 11 & $\mathrm{~s}$ \\
\hline PACT, Lid. & 70 & & 7 & S \\
\hline Philadelphia Thermal & & $4,498,800$ & 33 & $\mathrm{~S}$ \\
\hline Pitsburgh Thermal & & 598,882 & 1 & S. CW \\
\hline Public Service Co. of Colorado & 90 & $1,038,000 \#$ & 11 & $\mathbf{S}$ \\
\hline Rochester District Heating Cooperative & 110 & & 9 & $\mathrm{~S}$ \\
\hline St. Louis Thermal & & 999,559 & 22 & $\mathbf{S}$ \\
\hline Seattle Steam & 100 & 986,280 & 18.5 & $\mathbf{S}$ \\
\hline Toronto District Heating Corp. & 30 & $2,586,000$ & 12 & $\mathrm{~s}$ \\
\hline Trenton District Energy & 8 & 447,000 & & HW \\
\hline Trigen - Tulsa & 21 & & 2 & $\mathrm{~S}, \mathrm{CW}$ \\
\hline Trigen - London, Ontario & & 120,000 & 4 & $\mathbf{S}$ \\
\hline Trigen - Kansas City & 85 & & 9 & $\mathbf{S}$ \\
\hline Trigen - Nassau County & 20 & & 9 & $\mathrm{HW}, \mathrm{CW}$ \\
\hline United Illuminating & 3 & & $<1$ & HW, CW \\
\hline Willmar Public Utilities & 9 & 55,654 & 4 & HW. S \\
\hline Wisconsin Electric & 86 & $2,160,274$ & 28 & $\mathrm{~s}$ \\
\hline Youngstown Thermal & 90 & 496,320 & 6 & S \\
\hline Total & & $74,127,578$ & 529 & \\
\hline
\end{tabular}

aFor 1989 except where marked with \# (1988 data). 
Two measures of system size are shown: annual energy sales and miles of supply piping. Although these data were not available for all utilities, the total energy sales for the utilities with such data was more than $74 \times 10^{12}$ Btu, and the total length of supply pipe was 530 miles. This information will be useful in weighting the importance of the responses. For example, the needs of Consolidated Edison, with more than $50 \%$ of the total sales and $25 \%$ of the supply piping, are extremely significant.

Table 3 summarizes the types of piping installations and expansion devices used. Box conduit, solid pour, and prefabricated pipe conduit types are illustrated in Fig. 1. While $41 \%$ of the respond ents use prefabricated conduit (pipe-within-pipe), this is often only their newer pipe. A major exception is Consolidated Edison, whose standard design is a pipe-withinpipe with an annular space between the two.

The next most common installation is box conduit (36\%), followed by direct bury (32\%), solid pour (25\%), and tunnels (14\%). Although no definite figures are available, box conduit probably represents the greatest number of pipe miles for utilities other than Consolidated Edison.

Slip joints and bellows are by far the most common expansion devices, and many utilities use both types. Slip joints are used by $57 \%$ of the respondents, and bellows by $55 \%$, while only $9 \%$ use ball joints and $23 \%$ use expansion loops.

Typical or average intervals between expansion devices and between manholes are indicated in Table 4. The interval between expansion devices is relevant due to the acoustic attenuation caused by such devices if sensors are placed on the pipe surface. Interval between manholes is important if it is possible that the hot tap required for the ANL acoustic detection device can be done at manholes to minimize costs.

Of the 35 utilities providing steam pressure data, 16 provide high pressure and low pressure steam service (low pressure is defined here as 50 psi or less), 14 provide only high-pressure service, 2 provide only lowpressure service, and 1 distributes $800-$ psi superheated steam.

Of the 32 systems providing high-pressure service, 15 operated at 150 psi or less. Only 7 systems operated at pressures over 200 psi. 
Table 3. Summary of Pipe Installations and Expansion Devices

\begin{tabular}{|c|c|c|c|c|c|c|c|c|c|}
\hline \multirow[b]{2}{*}{ Name of system } & \multicolumn{5}{|c|}{$\begin{array}{l}\text { Types of plpe } \\
\text { installations }\end{array}$} & \multicolumn{4}{|c|}{$\begin{array}{c}\text { Types of } \\
\text { expansion devices }\end{array}$} \\
\hline & $\mathrm{BC}$ & SP & $\mathrm{T}$ & PC & $\mathrm{DB}$ & $\mathbf{S}$ & Bel & $\mathbf{B}$ & EL \\
\hline Alabama Power Company & $\bullet$ & & & $\cdot$ & & $\bullet$ & $\cdot$ & & \\
\hline Baltimore Thermal & - & & & & & - & & & \\
\hline Boston Thermal & - & - & & & & & - & & \\
\hline Central Heat Distribution (Vancouver) & & & & & - & - & - & & \\
\hline Cleveland Thermal & - & - & & - & & - & $\bullet$ & & \\
\hline Cogeneration Management Company & & & $\bullet$ & & & & & & \\
\hline $\begin{array}{l}\text { Concord Steam } \\
\text { Consolidated Edison }\end{array}$ & & & & & $\bullet$ & & $\bullet$ & & \\
\hline $\begin{array}{l}\text { Consolidated Edison } \\
\text { Dayton Power and Light }\end{array}$ & - & - & & $\cdot$ & & - & - & & $\bullet$ \\
\hline $\begin{array}{l}\text { Dayton Power and Light } \\
\text { Detrolt Edison }\end{array}$ & $\because$ & : & & & & : & & & . \\
\hline $\begin{array}{l}\text { Detroit Edison } \\
\text { District Energy St. Paul }\end{array}$ & & & & - & & 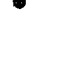 & - & & - \\
\hline Energy Networks Inc. & & & & - & & - & - & - & - \\
\hline Energy Systems Co. - Omaha & - & & & & & - & - & & \\
\hline Eugene Water and Electric Board & - & - & & - & - & - & . & & - \\
\hline Fairbanks Municipal Utllities & - & & & & $\bullet$ & - & - & & - \\
\hline Georgla Power Co. & & & & - & & - & - & & \\
\hline Harrisburg Steam Works & & & & $\bullet$ & - & & - & & \\
\hline Indianapolis Power and Light & & - & & & & $\bullet$ & & & \\
\hline Jamestown Board of Public Utllittes & & & & $\bullet$ & & & & & $\bullet$ \\
\hline $\begin{array}{l}\text { Kent County Public Works } \\
\text { Lansing Board of Power and Light }\end{array}$ & 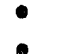 & & & $\bullet$ & $\bullet$ & $:$ & & $\bullet$ & \\
\hline $\begin{array}{l}\text { Lansing, Board of Power and Light } \\
\text { Mid-America Energy Resources }\end{array}$ & - & & & & $\bullet$ & & & • & \\
\hline Minneapolis Energy Center & & & - & $\bullet$ & & & & $\bullet$ & - \\
\hline Nashville Thermal & & & $\bullet$ & & $\bullet$ & - & & & \\
\hline NRG Thermal & - & & & - & & $\bullet$ & - & & \\
\hline Pacific Energy/Central Plants Inc. & & 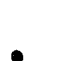 & & & & & & & \\
\hline $\begin{array}{l}\text { Pacific Gas and Electric } \\
\text { PACT, Ltd. }\end{array}$ & - & : & - & & & - & $\because$ & & \\
\hline & & & & - & - & & $\bullet$ & & \\
\hline Pltsburgh Thermal & & - & & & & & - & & \\
\hline Public Service Co, of Colorado & & & & - & & - & - & & \\
\hline Rochester District Heating Cooperative & - & & & & & - & & & - \\
\hline St. Louis Thermal & - & & & - & & - & - & & \\
\hline Seattle Steam & & - & & & $\bullet$ & & - & & \\
\hline Toronto District Heating Corp. & & & $\bullet$ & & - & - & & $\bullet$ & \\
\hline Trenton District Energy & & & & - & & & & & - \\
\hline Trigen - Tulsa & & & & - & & - & $\bullet$ & & \\
\hline Trigen - London, Ontario & & & & & & & & & \\
\hline Trigen - Kansas City & & & & & - & & - & & \\
\hline Trigen - Nassau County & & & & & & & & & \\
\hline United Illuminating & & & & & & & & & \\
\hline Willmar Public Utilities & & & & & & & & & \\
\hline Wisconsin Electric & - & & - & & - & $\bullet$ & - & & \\
\hline Youngstown Thermal & & - & & $\bullet$ & $\bullet$ & - & - & & \\
\hline Totals & 16 & 11 & 6 & 18 & 14 & 25 & 24 & 4 & 10 \\
\hline$\%$ of respondents & 36 & 25 & 14 & 41 & 32 & 57 & 55 & 9 & 23 \\
\hline
\end{tabular}

apipe Installations: $\mathrm{BC}=\mathrm{Box}$ condult $\mathrm{SP}=$ Solid pour; $\mathrm{T}=$ Tunnel $\mathrm{PC}=$ Prefabricated conduit or other pipc-within-pipe; $\mathrm{DB}=$ Direct Bury

bExpansion Devices: $\mathrm{S}=$ Slip; $\mathrm{Bel}=$ Bellows; $\mathrm{B}=\mathrm{Ball} ; \mathrm{EL}=$ Expansion loop. 
Table 4. Other System Details

\begin{tabular}{|c|c|c|c|c|c|c|}
\hline \multirow[b]{2}{*}{ Nameof system } & \multicolumn{2}{|c|}{$\begin{array}{c}\text { Typical or } \\
\text { averageintervals }\end{array}$} & \multicolumn{2}{|c|}{$\begin{array}{l}\text { Maximum } \\
\text { pressure } \\
\text { (ps) }\end{array}$} & \multicolumn{2}{|c|}{$\begin{array}{l}\text { Jondensate } \\
\text { return }\end{array}$} \\
\hline & $\begin{array}{l}\text { Betweeen } \\
\text { exp.units }\end{array}$ & $\begin{array}{l}\text { Between } \\
\text { manholes }\end{array}$ & HP & LP & Yes & No \\
\hline Alabama Power Company & 200 & 400 & 150 & & & - \\
\hline Baltimore Thermal & 200 & 200 & 180 & 35 & & - \\
\hline Boston Thermal & 75 & 460 & 190 & & & $\bullet$ \\
\hline Central Heat Distribution (Vancouver) & & & 190 & & - & \\
\hline $\begin{array}{l}\text { Cleveland Thermal } \\
\text { Cogeneration Management Company }\end{array}$ & 200 & 100 & .150 & 22 & & - \\
\hline Concord Steam & & & 165 & & & - \\
\hline Consolidated Edison & 200 & 500 & 200 & & & - \\
\hline Dayton Power and Light & 75 & 100 & 190 & 7 & & - \\
\hline Detrolt Edison & 450 & 450 & 125 & 50 & & - \\
\hline District Energy St. Paul & & 350 & 180 & & & \\
\hline Energy Networks Inc. & 100 & 750 & 150 & & & - \\
\hline Energy Systems Co. - Omaha & & 250 & 125 & & - & \\
\hline $\begin{array}{l}\text { Eugene Water and Electric Board } \\
\text { Fairbanks Municipal Utilities }\end{array}$ & 750 & 375 & 250 & $\begin{array}{l}15 \\
50\end{array}$ & - & \\
\hline Georgla Power Co. & & & 90 & 10 & & - \\
\hline Harrisburg Steam Works & 150 & 200 & 150 & 30 & & - \\
\hline $\begin{array}{l}\text { Indianapolis Power and Light } \\
\text { Janiestown Board of Public Utilities }\end{array}$ & 200 & 200 & 250 & 15 & & - \\
\hline Kent County Public Works & 450 & 550 & 150 & 15 & & - \\
\hline & 400 & 250 & 265 & 15 & & - \\
\hline $\begin{array}{l}\text { Mid-America Energy Resources } \\
\text { Minneapolis Energy Center }\end{array}$ & 350 & 350 & 250 & & - & \\
\hline Nashville Thermal & 200 & 200 & 150 & & - & \\
\hline NRG Thermal & 300 & 600 & $\vec{b}$ & & - & \\
\hline Pacific Energy/Central Plants Inc. & & & & & & \\
\hline Pacific Gas and Electric & & & 125 & & & - \\
\hline PACT, Ltd. & & & 150 & & - & \\
\hline Philadelphia Thermal & & & 225 & & & - \\
\hline Pittsburgh Thermal & 125 & 125 & 230 & & - & \\
\hline Public Service Co. of Colorado & & 225 & 125 & 30 & & - \\
\hline Rochester District Heating Cooperative & & 500 & 200 & & & - \\
\hline St. Louis Thermal & 200 & 200 & & & & - \\
\hline Seattle Steam & & 325 & 140 & 20 & & - \\
\hline Toronto District Heating Corp. & & & 250 & 25 & - & \\
\hline Trenton District Energy & & 250 & & & & NA \\
\hline Trigen - Tulsa & 150 & 400 & 150 & & - & \\
\hline Trigen - London, Ontario & & & & & & \\
\hline Trigen - Kansas City & 100 & 750 & 185 & 15 & & $\bullet$ \\
\hline Trigen - Nassau County & & & & & & NA \\
\hline $\begin{array}{l}\text { United Illuminating } \\
\text { Willmar Public Utilities }\end{array}$ & & & & & & \\
\hline Willmar Public Utilities & & & & 10 & & \\
\hline Wisconsin Electric & 125 & 350 & 160 & 12 & & n \\
\hline Youngstown Thermal & 350 & 350 & 150 & 15 & $\dot{11}$ & 22 \\
\hline Average of responses & 243 & 349 & 176 & 22 & $25 \%$ & $50 \%$ \\
\hline
\end{tabular}

a Detalls provided in AppenchxB. BNRG prowides superheated steamat 800 psi. Condensate 1s 150pst. 


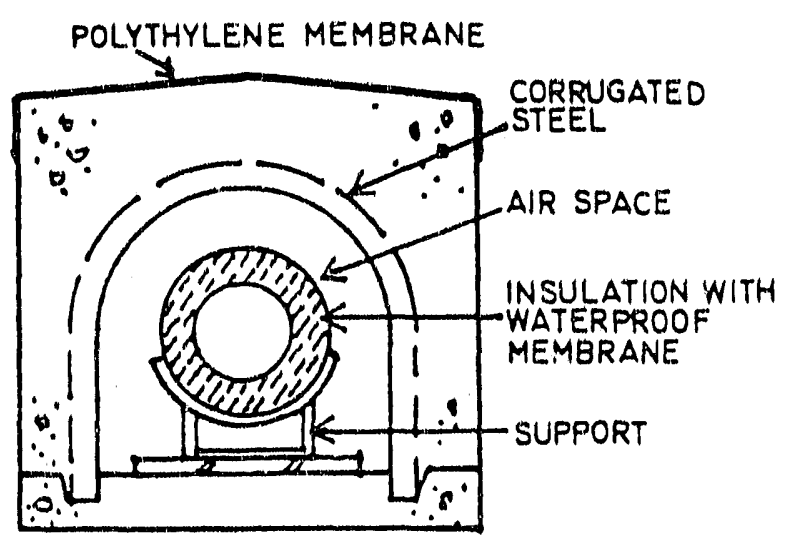

Box type concrete condust

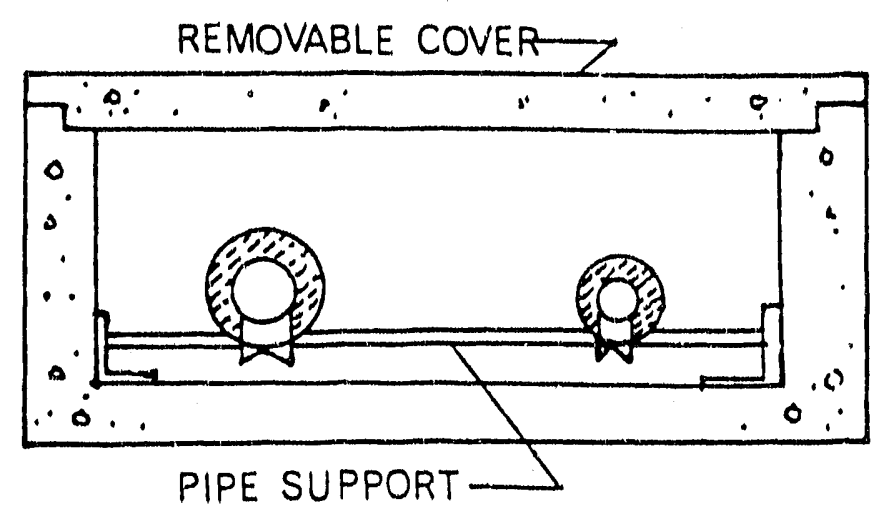

Removable cover on box type conduit

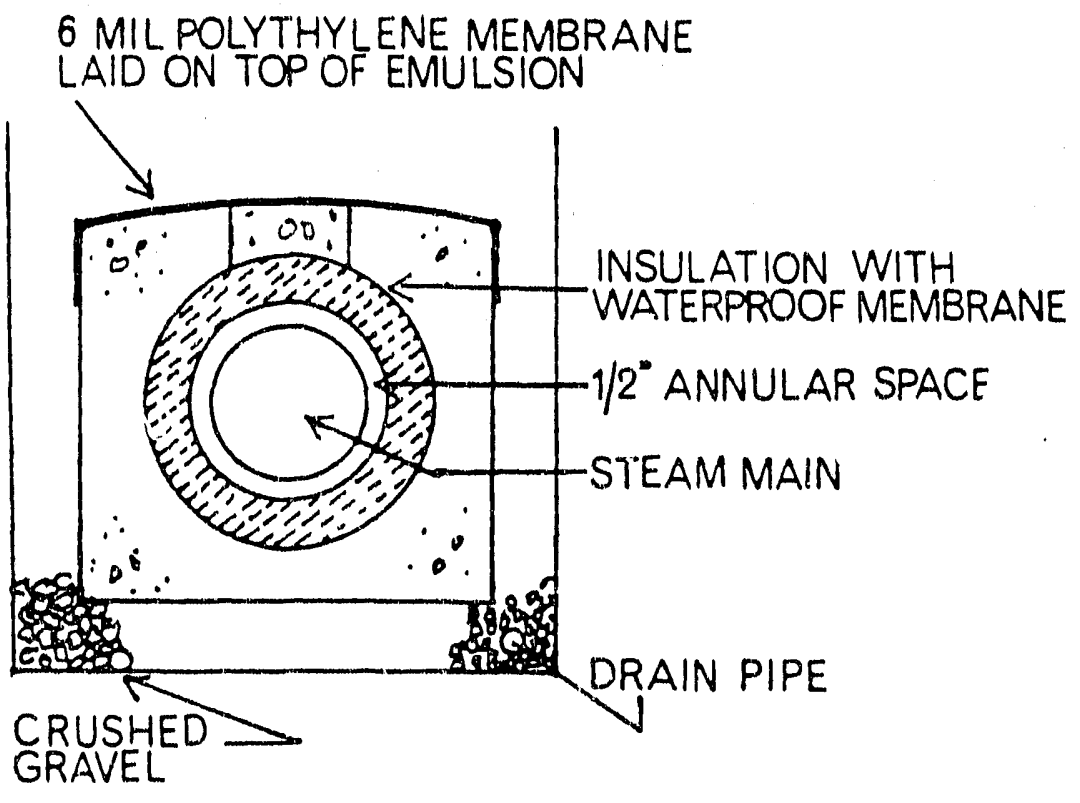

Solid pour conduit

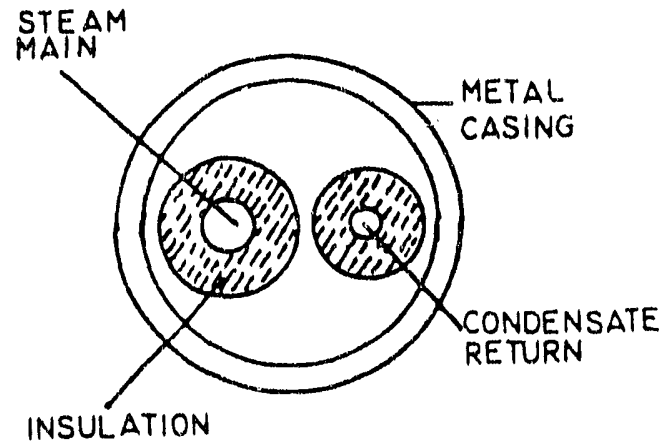

Metal casing, prefabricated conduit

Fig. 1. Basic Piping Designs (from "District Heating Handbook, Fourth Edition," Interriational District Heating and Cooling Association, 1983) 
"External sources" was cited as the most cormmon leak problem (Table 5). For example, leaks in city water mains and salt-laden street drainage are two iniportant types of external sources. The specific location of the leak in the distribution system would vary depending on the location of the external source.

Expansion devices are the most common specific locations of leaks; $30 \%$ reported that this is a trouble spot. Most of the systems with condensate return indicated that the condensate pipe is their biggest leak problem. Other trouble spots, in descending order of importance, are flanges, welds, valves, steam traps, roliers, and tees.

Eight steam comprnies indicated that they have condensate return. Of these systems, $44 \%$ indicated that the condensate pipe is their biggest leak problem.

\subsubsection{Leak Detection Practices}

In this report a distinction is made between "detection" (determining that a leak exists) and "location" (establishing the location of the leak).

Almost $75 \%$ of the respondents indicated that their primary means of detecting leaks is a report of visible steam from a manhole or customer installation (Table 6). Infrared is used by $11 \%$, while $9 \%$ monitor makeup water requirements to detect leaks. In-line electrical leak detection systems were installed in five systems, but only three are being used. The others have been abandoned due to extensive problems with false alarms and other deficiencies.

Several systems with condensate returns will typically replace an entire section of condensate line rather than attempt to locate the leak, because of general deterioration of the line.

Three-quarters of the respondents have found one or more methods effective to some extent in locating leaks (Table 7). Generally, once a leak is detected, its location is isolated between two manholes on the basis of visible steam. Because certain types of system components are weak spots (Table 4), as-built drawings are used to narrow down the possible location. Simply feeling the surface of the pavement for hot spots is used by $34 \%$ of the systems. Some type of acoustic technology is used by $23 \%$, while $16 \%$ use infrared for locating leaks. 
Table 5. Location of Leaks

\begin{tabular}{|c|c|c|c|c|c|c|c|c|c|}
\hline \multirow[b]{2}{*}{ Name of system } & \multicolumn{9}{|c|}{ Primary location of leaks ${ }^{a}$} \\
\hline & $\mathrm{ED}$ & Ex & $\mathbf{T r}$ & $\mathbf{W}$ & $\mathbf{V}$ & $\mathrm{F}$ & $\mathbf{R}$ & $\mathrm{CP}$ & $T$ \\
\hline Alabama Power Company & & & $\bullet$ & & & & & & \\
\hline Baltimore Thermal & & & & & & & - & & - \\
\hline Boston Thernual & $\bullet$ & & & & & & & & \\
\hline Central Heat Distribution (Vancouver) & & & & & & & & & \\
\hline Cleveland Thermal & & - & & & & & & & \\
\hline Cogeneration Management Company & & & & & & & & & \\
\hline $\begin{array}{l}\text { Concord Steam } \\
\text { Consolldated Edison }\end{array}$ & • & & & - & & $\bullet$ & & & \\
\hline $\begin{array}{l}\text { Consolidated Ealson } \\
\text { Dayton Power and Light }\end{array}$ & & $\bullet$ & & & & & & & \\
\hline Detroit Edison & - & - & & & & $\bullet$ & & & \\
\hline District Energy St. Paul & & & & & & & & & \\
\hline Energy Networks Inc. & - & & & $\bullet$ & $\bullet$ & & & & \\
\hline Energy Systems Co. - Omaha & $\bullet$ & & & & & & & $\bullet$ & \\
\hline Eugene Water and Electric Board & & & & $\bullet$ & & & & $\bullet$ & \\
\hline $\begin{array}{l}\text { Falrbanks Municipal Utilities } \\
\text { Georgla Power Co. }\end{array}$ & & & & & & & & & \\
\hline Harrisburg Steam Works & - & - & & & & & & & \\
\hline Indianapolis Power and Light & & - & & & & & & & \\
\hline Jamestown Board of Public Utilities & & & & & & & & & \\
\hline Kent County Public Works & & $\bullet$ & & & & & & & \\
\hline Lansing Board of Power and Light & $\bullet$ & & & & & $\bullet$ & - & & \\
\hline Mid-America Energy Resources & & & & & & & & & \\
\hline Munneapolis Energy Center & $\bullet$ & & & & $\bullet$ & & & $\bullet$ & \\
\hline $\begin{array}{l}\text { Nashville Thermal } \\
\text { NRG Thermal }\end{array}$ & & $\bullet$ & & & & & & $\because$ & \\
\hline $\begin{array}{l}\text { NRG Thermal } \\
\text { Pacific Energy/Central Plants Inc. }\end{array}$ & $\bullet$ & - & & & & - & & & \\
\hline $\begin{array}{l}\text { Pacific Energy/Central Plants Inc. } \\
\text { Pacific Gas and Electric }\end{array}$ & & & & & & & & & \\
\hline PACT, Ltd. & - & & & & & & & - & \\
\hline Philadelphia Thermal & & - & & - & & & & & \\
\hline Pittsburgh Thermal & & & & & - & - & & - & \\
\hline Public Service Co. of Colorado & & & & $\bullet$ & $\bullet$ & & & & \\
\hline Rochester District Heating Cooperative & & & $\bullet$ & & & & & & \\
\hline St. Louis Thermal & & $\bullet$ & & - & & & & & \\
\hline Seattle Steam & & - & & & & & & & \\
\hline Toronto District Heating Corp. & - & & & & & & & & \\
\hline Trenton District Energy & & $\bullet$ & & & & & & 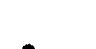 & \\
\hline Trigen - Tulsa & & & & & & & & $\bullet$ & \\
\hline Trigen - London, Ontario & & & & & & & & & \\
\hline Trigen - Kansas City & & $\bullet$ & & & & & & & \\
\hline $\begin{array}{l}\text { Trigen - Nassau County } \\
\text { United Illuminating }\end{array}$ & & & & & & & & & \\
\hline Willmar Public Utilities & & & & & & & & & \\
\hline Wisconsin Electric & - & - & & & & & & & \\
\hline Youngstown Thermal & - & $\bullet$ & & & & & & & \\
\hline Total & 13 & 15 & 2 & 6 & 4 & 5 & 2 & 8 & 1 \\
\hline$\%$ of respondents & 30 & 34 & 5 & 14 & 9 & 11 & 5 & 18 & 2 \\
\hline
\end{tabular}


Table 6. Leak Detection Methods

\begin{tabular}{|c|c|c|c|c|c|}
\hline \multirow[b]{2}{*}{ Name of system } & \multicolumn{4}{|c|}{ Methods used for detecting leaks } & \multirow[b]{2}{*}{$\begin{array}{l}\text { Depth } \\
\text { of pipe }\end{array}$} \\
\hline & $\begin{array}{l}\text { Visible } \\
\text { steam }\end{array}$ & $\begin{array}{l}\text { Infra- } \\
\text { red }\end{array}$ & $\begin{array}{l}\text { Makeup } \\
\text { water }\end{array}$ & $\begin{array}{l}\text { Wire in } \\
\text { conduit }\end{array}$ & \\
\hline Alabama Power Company & $\cdot$ & & & & $3-4$ \\
\hline Baltimore Thermal & $\bullet$ & & & & \\
\hline Boston Thermal & - & & & & 10 \\
\hline Central Heat Distribution (Vancouver) & & & & & \\
\hline Cleveland Thernal & - & & & & \\
\hline Cogeneration Management Company & - & & & & \\
\hline Concord Steam & - & & & & \\
\hline Consolidated Edison & - & & & & \\
\hline Dayton Power and Light & - & & & & 3-9 \\
\hline Detroit Edison & $\bullet$ & & & & $8-10$ \\
\hline Distryct Energy St. Paul & & & & - & $2-4$ \\
\hline Energy Networks Inc. & - & & & & $2-8$ \\
\hline Energy Systems Co. - Omaha & - & & & & \\
\hline Eugene Water and Electric Board & & & & & $2-15$ \\
\hline Fairbanks Municipal Utilit & - & & - & & 4-6 \\
\hline Georgla Power Co. & $\bullet$ & & & & \\
\hline Harrisburg Steam Works & - & & & & $3-10$ \\
\hline Indianapolis Power and Light & - & & & & $2-10$ \\
\hline Jamestown Board of Public Utulities & & & & $\bullet$ & \\
\hline Kent County Public Works & - & - & & & \\
\hline Lansing Board of Power and Light & - & & & & \\
\hline Mid-America Energy Resources & & & & & \\
\hline Minneapolss Energy Center & - & & & & \\
\hline Nashville Thermal & & - & & & \\
\hline NRG Thermal & - & & - & & 8 \\
\hline Pacific Energy/Central Plants Inc. & - & & $\bullet$ & & \\
\hline Pacific Gas and Electric & - & & & & \\
\hline PACT, Ltd. & - & & & & \\
\hline Philadelphia Thermal & & & & & \\
\hline Pittsburgh Thermal & $\bullet$ & & & & \\
\hline Public Service Co. of Colorado & & - & & & \\
\hline Rochester District Heating Cooperative & - & - & & & \\
\hline St. Louls Thermal & - & & & & \\
\hline Seattle Steam & - & & & & \\
\hline Toronto District Heating Corp. & - & & & & \\
\hline Trenton District Energy & & & & & $2-9$ \\
\hline Trigen - Tulsa & & - & & & \\
\hline Trigen - London, Ontario & - & & & & \\
\hline Trigen - Kansas City & - & & & & $4-10$ \\
\hline Trigen - Nassau County & - & & - & & \\
\hline United Illuminating & & & & & \\
\hline Willmar Public Utilities & & & & - & \\
\hline Wisconsin Electric & • & & & & $5-18$ \\
\hline Youngstown Thermal & - & & & & $3-10$ \\
\hline Total & 32 & 5 & 4 & 3 & \\
\hline$\%$ of respondents & 73 & 11 & 9 & 7 & \\
\hline
\end{tabular}


Table 7. Leak Location Methods

\begin{tabular}{|c|c|c|c|c|c|c|}
\hline \multirow[b]{2}{*}{ Name of system } & \multicolumn{4}{|c|}{ Methods found useful a } & \multicolumn{2}{|c|}{$\begin{array}{l}\text { Methods } \\
\text { tried } \\
\text { without } \\
\text { success }\end{array}$} \\
\hline & FS & A & IR & Other & A & IR \\
\hline & - & & & & $\bullet$ & \\
\hline $\begin{array}{l}\text { Baltimore Thermal } \\
\text { Boston Thermal }\end{array}$ & - & • & & & & 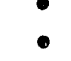 \\
\hline $\begin{array}{l}\text { Central Heat Distribution (Vancouver) } \\
\text { Cleveland Thermal }\end{array}$ & & • & & Leaks not a problem & & \\
\hline $\begin{array}{l}\text { Cogeneration Management Company } \\
\text { Concord Steam }\end{array}$ & & $\bullet$ & & Leak obvious in tunnel & & \\
\hline Consolidated Edison & - & $\because$ & & & & \\
\hline $\begin{array}{l}\text { Dayton Power and Light } \\
\text { Detroit Edison }\end{array}$ & & & $\bullet$ & Dry spot on rainy day & & \\
\hline $\begin{array}{l}\text { Detroit Edison } \\
\text { District Energy St. Paul } \\
\text { Energy Networks Inc. }\end{array}$ & & $\bullet$ & & Leaks not a problem & & \\
\hline $\begin{array}{l}\text { Energy Networks Inc. } \\
\text { Energy Systems Co. - Omaha } \\
\text { Eugene Water and Electric Board }\end{array}$ & & & & Use elec. probe if needed & & $\bullet$ \\
\hline $\begin{array}{l}\text { Eugene Water and Electric Board } \\
\text { Fairbanks Municipal Utilities }\end{array}$ & $\bullet$ & & $\bullet$ & & $\bullet$ & \\
\hline $\begin{array}{l}\text { Georgia Power Co. } \\
\text { Harrisburg Steam Works }\end{array}$ & - & & & & & \\
\hline $\begin{array}{l}\text { Harrisburg Steam Works } \\
\text { Indianapolis Power and Light } \\
\text { Jamestown Board of Public Utilities }\end{array}$ & - & & & & & \\
\hline $\begin{array}{l}\text { Jamestown Board of Public Utilities } \\
\text { Kent County Public Works }\end{array}$ & • & & • & In-line elec. system & & \\
\hline $\begin{array}{l}\text { Lansing Board of Power and Light } \\
\text { Mid-America Energy Resources }\end{array}$ & & & & $\begin{array}{l}\text { Hand-held thermal meter } \\
\text { Leaks not a problem }\end{array}$ & & \\
\hline $\begin{array}{l}\text { Minneapolis Energy Center } \\
\text { Nashville Thermal }\end{array}$ & $\bullet$ & & $\bullet$ & Leaks obvious in tunnels & & \\
\hline $\begin{array}{l}\text { NRG Thermal } \\
\text { Pacific Energy/Central Plants Inc. }\end{array}$ & & & & $\begin{array}{l}\text { Escape of vapor or water } \\
\text { Escape of vapor or water }\end{array}$ & & $\bullet$ \\
\hline $\begin{array}{l}\text { Pacific Gas and Electric } \\
\text { PACT, Ltd. }\end{array}$ & • & $\bullet$ & & & & $\bullet$ \\
\hline $\begin{array}{l}\text { Philadelphia Thermal } \\
\text { Pittsburgh Thermal }\end{array}$ & $\bullet$ & & & Leaks not a problem & & \\
\hline $\begin{array}{l}\text { Pittsburgh Thermal } \\
\text { Public Service Co. of Colorado }\end{array}$ & 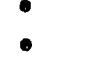 & & & & • & \\
\hline $\begin{array}{l}\text { Rochester District Heating Cooperative } \\
\text { St. Luis Thermal }\end{array}$ & & & $\bullet$ & Drill thru roof of conduit & • & \\
\hline $\begin{array}{l}\text { Seattle Steam } \\
\text { Toronto District Heating Corp. }\end{array}$ & & - & $\bullet$ & Leaks not a problem & & \\
\hline $\begin{array}{l}\text { Trenton District Energy } \\
\text { Trigen - Tulsa }\end{array}$ & - & & - & $\begin{array}{l}\text { Leaks not a prodlem } \\
\text { Replacing cond. line }\end{array}$ & & \\
\hline Trigen - London, Ontariob & & & & Dry spot on rainy day & & \\
\hline $\begin{array}{l}\text { Trigen - Kansas City } \\
\text { Trigen - Nassau County }\end{array}$ & & - & & $\begin{array}{l}\text { Heath good on HP, not on LF } \\
\text { Leaks not a problem }\end{array}$ & & \\
\hline $\begin{array}{l}\text { United Illuminating } \\
\text { Willmar Public Utilities }\end{array}$ & & & & & & \\
\hline & - & & & $\begin{array}{l}\text { Leaks not a problem } \\
\text { Leaks not a problem }\end{array}$ & $\bullet$ & \\
\hline $\begin{array}{l}\text { Wisconsin Electric } \\
\text { Youngstown Thermal }\end{array}$ & - & $\bullet$ & & & & \\
\hline $\begin{array}{l}\text { Total } \\
\% \text { of respondents }\end{array}$ & $\begin{array}{l}15 \\
34\end{array}$ & $\begin{array}{l}10 \\
23\end{array}$ & $\begin{array}{l}7 \\
16\end{array}$ & & $\begin{array}{l}8 \\
18\end{array}$ & $\begin{array}{l}6 \\
14\end{array}$ \\
\hline
\end{tabular}

aFS = Feel street or vault surface; $A=$ Acoustic; $I R=$ Infrared.

bSystem is very old, and operator indicated that no money would be expended on leak repair. Operator hopes to expand system significantly, at which time in-line leak detection system will be installed. 
The following is a summary of the experiences of utilities that have used "acoustic" technologies successfully (in several cases, the devices actually measure vibration).

- Baltimore Thermal: Heath system, bought four years ago for about $\$ 1,000$. A receptor, of 3-4 in. diameter, is placed on pavement and moved 3-4 in. at a time. Have a staff person who uses the device effectively. Describes accuracy as within 4-5 ft. However, the company is interested in the ANL technology in order to further improve effectiveness.

- Cleveland Thermal: Heath system; price about $\$ 2000$. Staff person required time to develop a "good ear." Sandy soils in area; system doesn't work with clay soils. Must use between 2:00-5:00 a.m., when background noise is minimal.

- Concord Steam: Use city water department's acoustic device, a Heath Aquascope. An acoustic sensor is placed directly on the pavement or in contact with a valve. Where only soil is above the pipe, a bar must be driven down to contact the pipe to obtain a good signal.

- Consolidated Edison: Sometimes uses bar-hole method, where bar is driven down to contact the conduit. However, this is not always possible due to obstruction by other utilities (probably $30 \%$ of system). Bar-holing is also a safety concern.

- Detroit Edison: Drills hole in pavement and inserts sonic probe to contact the conduit; repeats this every foot or so in area in where the leak is suspected. Describes accuracy as "hit or miss." Company is interested in the ANL technology.

- Harrisburg Steam Works: Use the "STS Water Leak Pinpointing Instrument" made by Paul Michael \& Associates, Inc. (814-2388533). Although Dr. Michael was reluctant to share specifics on this vibration-measuring device, including the frequencies at which it operates, he did provide the information shown in Appendix C. Dr. Michael sells his device mostly to water utilities, but Harrisburg bought one three years ago, and now several other steam systems have bought the instrument or plan to do so. 
Harrisburg indicated that it works well but needs a quiet background, so it is used the night. Sets on a steel tripod on the pavement. Dr. Michael prices the device at $\$ 3200$.

- Pacific Gas and Electric: Can't remember name of maker of the device, but thinks it might be Heath. Works well except when background noise is significant.

- Seattle Steam: Bought a device from Dr. Michael (see Harrisburg notes) for $\$ 2600$ three months ago. Works very well on direct buried pipe, but is tricky with conduit.

- Trigen-Kansas City: Uses Heath Aquascope on high-pressure lines, but it does not work on low-pressure lines. Apparently, sensitivity is too low to detect leaks in the 15-psi low-pressure lines.

- Youngstown Thermal: Borrows Cleveland Thermal's acoustic device. Works well, but requires practice to use effectively. However, the company is interested in the ANL, technology in order to further improve effectiveness.

Of thesc 10 utilities currently using acoustic technologies with some success, five are interested in the ANL technology because they feel that the current methods are not as effective as is desirable..

Acoustic leak location technology has been tried without success by $18 \%$ of respondents. Among the potential reasons why some utilities were able to successfully use acoustic devices while others were unsuccessful are these: (a) technology used, (b) soil type, (c) staff experience/expertise, and (d) pipe depth. The influence of these factors on the eight utilities that unsuccessfully tried acoustic devices was not always clear. Generally, if the equipment is no longer used the utility was not able to describe the device in detail. However, the following notes were obtained on these experiences.

- Alabama Power: "Hand-held sonic tester."

- Boston Thermal: Apparently tried Cleveland Thermal's Heath system. They noted that, in contrast to the Cleveland Thermal 
area, where the technology is used successfully, the solls in Boston are not sandy. Pipe depth is about $10 \mathrm{ft}$.

- Eugene Water and Electric Board: Unsuccessfully tried "Geophones" used by city water department, described as a stethoscope placed on the pavement. Pipe is 2-15 ft. deep.

- Indianapolis Power and Light: Tried Heath technology without success 3-4 years ago. Pipe depth varies significantly, from 2 to $10 \mathrm{ft}$.

- Kent County Public Works: Tried water department acoustic device.

- Pittsburgh Thermal: Tried acoustic leak location contractor.

- St. Louis Thermal: Borrowed and used Cleveland Thermal's equipment, without success. Also tried a leak location contractor.

- Wisconsin Electric: Bought an acoustic device (no details avallable) about 10 years ago, but was unsuccessful with it. Needed to bar-hole down due to depth of pipe, which ranges from 5 to $18 \mathrm{ft}$.

While seven systems have successfully used infrared technology, six others have tried this method but found it not effective. Pipe depth may also he a significant factor in these differences.

\subsubsection{Interest in ANL Acoustic Technology}

Overall, $41 \%$ of the respondents indicated interest in using the ANL acoustic technology, while $59 \%$ indicated no interest (Table 8 ). Utilities that were not interested were asked to explain why; some utilities gave more than one reason. Responses are summarized below.

- Leaks are not a significant problem: $58 \%$

- Current methods work well: $\quad 43 \%$

- Don't want to consider using hot tap: $15 \%$ 
Table 8. General Interest in ANL Technology

\begin{tabular}{|c|c|c|c|c|c|c|}
\hline \multirow[b]{3}{*}{ Name of system } & \multirow{2}{*}{\multicolumn{2}{|c|}{$\begin{array}{l}\text { Interested in } \\
\text { using ANL } \\
\text { technology? }\end{array}$}} & \multicolumn{4}{|c|}{ If not, why not? } \\
\hline & & & \multirow{2}{*}{$\begin{array}{l}\text { Leaks } \\
\text { not a } \\
\text { problem }\end{array}$} & \multirow{2}{*}{$\begin{array}{l}\text { Current } \\
\text { method } \\
\text { works }\end{array}$} & \multirow{2}{*}{$\begin{array}{c}\text { Don't } \\
\text { want } \\
\text { hot tap }\end{array}$} & \multirow[b]{2}{*}{ Othe } \\
\hline & Yes & No & & & & \\
\hline Alabama Power Company & & - & - & - & - & \\
\hline Baltimore Therrnal & - & & & & & \\
\hline Boston Therrnal & - & & & & & \\
\hline Central Heat Distribution (Vancouver) & & - & - & & & \\
\hline Cleveland Thermal & & - & & - & & \\
\hline Cogeneration Management Company & & - & & - & & \\
\hline Concord Steam & & - & - & - & & \\
\hline Consolidated Edison & - & & & & & \\
\hline Dayton Power and Light & & $\bullet$ & & - & & \\
\hline Detrolt Edison & อ & & & & & \\
\hline District Energy St. Paul & & - & - & - & & \\
\hline Energy Networks Inc. & - & & & & & \\
\hline Energy Systems Co. - Omaha & & - & & & & \\
\hline Eugene Water and Electric Board & & - & - & - & & \\
\hline Fairbanks Municipal Utilities & & - & - & & & \\
\hline Georgla Power Co. & & - & & & & - \\
\hline Harrisburg Steam Works & & - & & - & & \\
\hline Indianapolis Power and Light & - & & & & & \\
\hline Jamestown Board of Public Utilities & & - & $\bullet$ & & & \\
\hline Kent County Public Works & - & & & & & \\
\hline Lansing Board of Power and Light & - & & & & & \\
\hline Mid-America Energy Resources & & - & - & & & \\
\hline Minneapolis Energy Center & - & & & & & \\
\hline Nashville Thermal & & - & & - & & \\
\hline NRG Thermal & - & & & & & \\
\hline Pacific Energy/Central Plants Inc. & - & & & & & \\
\hline Pacific Gas and Electric & & - & & & - & \\
\hline PACT, Ltd. & - & & & & & \\
\hline Philadelphia Thermal & & - & - & & & \\
\hline Pittsburgh Thermal & - & & & & & \\
\hline Public Service Co. of Colorado & & - & & & - & \\
\hline Rochester District Heating Cooperative & & - & - & & - & \\
\hline St. Louis Thermal & $\bullet$ & & & & & \\
\hline Seattle Steam & & - & & - & & \\
\hline Toronto District Heating Corp. & & $*$ & - & & & \\
\hline Trenton District Energy & - & & & & & \\
\hline Trigen - Tulsa & - & & & & & - \\
\hline Trigen - London, Ontario & & - & & & & \\
\hline Trigen - Kansas City & - & & & & & \\
\hline Trigen - Nassau County & & $\bullet$ & - & & & \\
\hline United Illuminating & & a & - & & & \\
\hline Willmar Public Utilities & & - & - & & & \\
\hline Wisconsin Electric & & - & - & & & \\
\hline Youngstown Thermal & - & & & & & \\
\hline Total & 18 & 26 & 15 & 11 & 4 & 2 \\
\hline$\%$ of respondents & 41 & 59 & 58 & 42 & 15 & 8 \\
\hline
\end{tabular}


Although only four respondents who are not interested in the ANL technology noted the hot tap as the reason, reservations about hot taps are pervasive and very significant. Concerns about hot taps focus on safety, cost. and introduction of additional potential leak sites.

Listed below are notes on each utility that expressed interest in the ANL technology, including their thoughts on hot taps:

- Baltimore Thermal's leak problems are in low-pressure (20-35 psi) lines. Key concern is minimizing labor costs.

- Boston Thermal has isolation valves at each manhole, and would shut ofi a section of line to weld in the tap rather than install a hot tap. On average, the system loses about four bellows every year and develops several other leaks.

- Consolidated Edison is concerned about hot taps from all three standpoints noted above. The company bought hot-tap equipment 10 years ago, and has used it, generally for 3-6 in. taps. The equipment is too large to fit into a manhole. Based on experience, a hot tap costs about $\$ 4000$ ( $\$ 3000$ for the excavation plus $\$ 1000$ for the tap, assuming two men for one day at $\$ 30 / \mathrm{hr}$.

- Detrolt Edison stated that cost-effective, quick hot-tap service from a contractor would be essential. The company does not allow its staff to do hot taps. About 40 leaks are repaired annually, at a cost of \$10,000-15,000 per excavation. Annual budget for leak work is about $\$ 1$ million.

- Energy Networks Inc. noted that although leaks are not a particular problem, some of its older steam pipe is almost 30 years old; the company is interested in the ANL technology if it proves to be cost-effective.

- Indiarapolis Power and Light noted that its leak problems are almost all in the low-pressure line (10-15 psi), and that hot taps in a low-pressure line are not a problem. (Of the 11 systems providing both high-and low-pressure service, 5 indicated that the low-pressure system is where their leak problems are. The 
company spends about $\$ 1.25$ million annually on leak detection and repair.

- Kent County expressed reservations about hot taps. Quick restoration of service is key.

- Lansing Board of Power and Light is concerned about corrosion potential at hot-tap sites. Leaks do not receive a high priority at present.

- Minneapolis Energy Center felt that a hot tap could be done in a manhole if the leak is small enough.

- NRG Thermal's leak problems are unusual: they generally occur in a 150-psi condensate line. Because a portion of the line is located along railroad tracks, shoring requirements make excavation very expensive (perhaps $\$ 25,000$ per hole). Hot taps of less than $1 / 2 \mathrm{in}$. do not appear to be a problem and could be done in vaults, but cost is estimated at about $\$ 1000$ per tap.

- Pacific Energy Co./Central Plants Inc. is interested in the ANL technology, but needs are unusual because most of its systems are chilled water or high-temperature hot water; only a small amount of steam service is provided.

- $\quad$ PACT, Ltd. is fairly successful in locating leaks, but is interested in improvement. The company is concerned about hot taps, particularly in confined spaces.

- Pittsburgh Thermal's primary concern is leaks in its condensate lines.

- $\quad$ St. Louis Thermal would not buy the ANL acoustic equipment but would be interested in contracting with a company that owns the equipment. 
- Toronto District Heating Corp. has problems in locating leaks in its low-pressure (15 psi) line. As a result, the company is interested in the ANL technology if the hot taps can be done in manholes, so excavation would not be necessary.

- Trenton District Energy and Trigen-Tulsa are interested for the long term, although leaks are currently not a major problem for elther company.

Most of the companies that expressed interest are looking for a mobile system to be implemented as needed (Table 9). Only two expressed interest in a permanent leak detection and location system.

All of the companies expressing overall interest in the ANL technology would consider hosting a field test, depending on specifics (particularly $\cos$ t).

\subsubsection{European Experience}

The following descriptions of European leak location practices are based on discussions with these individuals:

- Dr. Hans Mortensen, President of the Metropolitan Copenhagen Heating Transmission Co. In addition to managing the Copenhagen system, which has 30 miles of twin pipe, Dr. Mortensen is very active in the International Energy Agency on district heating matters.

- $\quad$ Sture Andersson, who has served as Production Manager of the Malmö Energy Authority in Malmö, Sweden, and as Chairman of District Heating Technology at Värmeforsk, the Swedish Thermal Energy Research Institute. He is currently responsible for Research and Development at Malmö Energy, and is Professor in district heating at the Institute of Technology in Lund.

- $\quad$ Eric Peterson of A/S Bjeld \& Lauridsen, a Danish company that provides infrared leak detection and location services throughout Europe. 
Table 9. Specific Interest in ANL Technology

\begin{tabular}{|c|c|c|c|c|}
\hline \multirow[b]{2}{*}{ Narne of system } & \multicolumn{2}{|c|}{$\begin{array}{c}\text { Types of system } \\
\text { of thiterest }\end{array}$} & \multicolumn{2}{|c|}{$\begin{array}{l}\text { Interested } \\
\text { in fleld } \\
\text { test? }\end{array}$} \\
\hline & $\begin{array}{c}\text { Permanent } \\
\text { system }\end{array}$ & $\begin{array}{l}\text { Moblle } \\
\text { system }\end{array}$ & Yes & No \\
\hline Alabama Power Company & & & & \\
\hline Baltimore Thermal & - & - & - & \\
\hline Boston 'Thermal & & - & - & \\
\hline Central Heat Distribution (Vancouver) & & & & \\
\hline Cleveland Thermal & & & & \\
\hline Cogeneration Management Company & & & & \\
\hline Concord Steam & & & & \\
\hline Consolidated Edison & & - & a & \\
\hline Dayton Power and Light & & & & \\
\hline Detrolt Edison & & - & - & \\
\hline District Energy St. Paul & & & & \\
\hline Energy Networks Inc. & & & - & \\
\hline Energy Systems Co. - Omaha & & & & \\
\hline Eugene Water and Electric Board & & & & \\
\hline Falrbanks Munlcipal Utilities & & & & \\
\hline Georgla Power Co. & & & & \\
\hline Harrisburg Steam Works & & & & \\
\hline Indlanapolis Power and Light & & & - & \\
\hline Jamestown Board of Public Utilities & & & & \\
\hline Kent County Public Works & - & & - & \\
\hline Lansing Board of Power and Light & & - & - & \\
\hline Mid-America Energy Resources & & & & \\
\hline Minneapolis Energy Center & & & - & \\
\hline Nashville Thermal & & & & \\
\hline NRG Thermal & & - & - & \\
\hline Pacific Energy/Central Plants Inc. & & • & - & \\
\hline Pacific Gas and Electric & & & & \\
\hline PACT, Ltd. & & - & . & \\
\hline Phlladelphla Thermal & & & & \\
\hline Pittsburgh Thermal & & - & - & \\
\hline Public Service Co. of Colorado & & & & \\
\hline Rochester District Heating Cooperative & & & & \\
\hline St. Louls Thermal & & - & - & \\
\hline Seattle Steam & & & & \\
\hline Toronto District Heating Corp. & & & & \\
\hline Trenton District Energy & & & - & \\
\hline Trigen - Tulsa & & & - & \\
\hline Trigen - London, Ontario & & & & \\
\hline Trigen -- Kansas City & & & - & \\
\hline Trigen - Nassau County & & & & \\
\hline United Illuminating & & & & \\
\hline Willmar Public Utilities & & & & \\
\hline Wisconsin Electric & & & & \\
\hline Youngstown Thermal & & & & \\
\hline Total & 2 & 10 & 18 & \\
\hline$\%$ of respondents & 5 & 23 & 41 & \\
\hline
\end{tabular}


Electric Alarm Systems: In-line electric alarm systems generally were installed during construction of European district heating systems after approximately 1975. Initially, many of these systems had significant problems with false alarms and other malfunctions, due to poor quality control during the manufacture of prefabrtcated pipe sections, as well as to bad connections between pipe sections in the field. (Notably, these same types of problems have been visible in North American installations. This has resulted in considerable efforts to "debug" these systems and, in two cases, abandonment of the alarm system.) These problems have apparently been solved in Europe through attention to proper workmanship, both in the factory and in the field.

Infrared Imaging: The eleciric alarm systems are sometimes augmented with infrared techniques; in older systems, infrared is the primary leak detection and location method. Infrared images can be taken with a camera mounted on the roof of a car or on an airplane flying at a altitude of no more than $300 \mathrm{~m}$.

Infrared imaging is best done at night when it is not raining and when there is no snow on the ground. Fog is also problematic. The best images are generally obtained in spring or fall.

The use of infrared is much more widespread in Europe than in North America, at least in part because hot water, rather than stearn, is the primary medium of heat transmission in European DH systems. The higher temperatures in steam piping apparently result in more blurring of the infrared image, thereby reducing its value in pinpointing the location of leaks.

Another factor is pipe depth. Bjeld \& Lauridsen has stated that the infrared technology is useful in examining pipes no more than $2 \mathrm{~m}$ deep. Danish district heating pipes, for example, are normally about $1 \mathrm{~m}$ deep.

At the Studsvik Research Institute in Sweden, thermography is now being further developed so that it can not only detect and locate leaks but also quantify the extent of heat loss.

Acoustic Technologies: Almost two-thirds of the district heating piping in what was formerly West Germany were installed without in-line 
electric alarm systems. To address the needs of these systems, work has been done to develop an acoustic leak location technology called "Lokal." This technique is simllar to that being pursued by ANL, 1.e., correlation analysis of acoustic signals from sensors placed on each side of the suspected leak area. However, the sensors are placed on the pipe rather than in-stream, as has become necessary to provide accuracy in location of leaks in steam pipes. The German work is directed toward hot water pipes. The development of "Lokal" was undertaken under the auspices of the IEA during 1984-87, and an IEA report was published.

Dyes: One more technique being developed for leak detection is the introduction of a dye into $\mathrm{DH}$ water. Although the purposes of this technique (detecting leaks into building domestic hot water or into the bullding substation) are different than that of the leak detection technology being developed by ANL, it is described here as a matter of interest.

In Sweden, only a single-wall heat exchanger separates district hot water from the domestic hot water supply for the bulldings served. As a result., considerable attention is paid to preventing leaks from the district system into the domestic hot water supply. To address this issue, tests were conducted with a dye called pyranine. The results were encouraging, and even small leaks could be detected.

\subsection{Conclusions from Survey}

1. The extent to which leak detection is important varies considerably from utility to utility.

- At least three of the larger utilities sperd $\$ 1$ million or more each year locating and repairing leaks.

- One-half of the respondents do not consider leaks to be a problem and/or are satisfied with current leak location methods.

- More than one-third (34\%) of the respondents do not consider leaks a significant problem.

- One quarter of the respondents are satisfied with their current methods for locating leaks. Within this group, $9 \%$ also indicated that leaks are not a problem. 
2. The most common leak location method is decidedly "low-tech": feeling the pavement to see where it is hottest and/or trouble-spot components using as-built drawings.

3. Almost one-quarter (23\%) of the respondents have found an acoustic technology useful to some extent in leak location, while $18 \%$ have tried an acoustic technology without success.

- A particular acoustic technology that has been used with good success by one utility may be totally ineffective for another.

- The effectiveness of various acoustic or vibration-sensing devices appears to depend on a variety of factors, including the particular acoustic device used, staff expertise/experience, soll type, and pipe depth.

- Existing acoustic technologies are relatively inexpensive (several thousands of dollars).

- One-half of the respondents that found an existing acoustic technology useful also stated that they are interested in the ANL technology because their current methods are not as effective as desirable.

4. There is significant interest in the ANL technology, particularly among the larger steam utilities.

- More than $40 \%$ of the utilities surveyed are interested in using the acoustic leak detection and location technology being developed by ANL.

- The utilities interested in the ANL technology represent $76 \%$ of the total thermal energy sales by the surveyed utilities for which sales data were avallable.

- Of the utlities that expressed an interest in the ANL technology, 28\% do not feel that leak detection is a high-priority problem. 
- Of the utilities expressing no interest in the ANL technology, the following reasons were cited: leaks are not a problem (58\%); current methods work well $(42 \%)$; don't want to do hot taps (15\%).

5. The market for the ANL technology is likely to be limited to a relatively few large steam systems.

- The likely capital cost of the ANL, technology (\$40,000-50,000, according to $A N L)$ is very high relative to other leak location technologies.

- However, this cost could be quickly recouped (due to the high cost of excavation) by utilities with a significant number of leaks and for whom the existing acoustic or other technologies do not work.

6. Most utilities are reluctant to do hot taps, and this presents a significant potential barrier to the use of the ANL technology.

- Concern about hot taps appears to be based on prior experience with large (several-inch) hot taps.

- Concerns about hot taps include safety, cost, and introduction of additional potential leak sites.

- To minimize overall operational costs of the ANL technology, it is important that the hot tap be performed in a manhole.

- The safety and cost problems with the size of tap likely required with the ANL technology ( $1 / 2 \mathrm{in}$. or less) should be considerably reduced compared to larger hot taps; this must be confirmed, quantified, and demonstrated.

\section{Acoustic Leak Location by Cross-Correlation Analysis}

A few examples of leak location by cross-correlation analysis of acoustic signals generated by a leak are presented to illustrate the potential for success and also the problems associated with this technology. 


\subsection{Leak Location with a Commercially Avallable Correlator at the ANL Steam Leak Facllity}

Using leaks generated in the ANL steam leak facility, ${ }^{1}$ we evaluated a . Metravib leak locator. In the Metravib system, accelerometers transmit signals to a central processing unit via radio waves. The Metravib unit has fixed-frequency windows; those evaluated were 400-1450,400-2200, and 400-3000 Hz. Correlation peaks from the Metravib unit were observed with sensors located 6.4 and $12.8 \mathrm{~m}$ from the leak. Steam pressures in the range of 40-70 psi wel: used. The window of $400-3000 \mathrm{~Hz}$ was optimal for the Metravib system. With the two lower-frequency windows, no correlation peak associated with the leak was observed. One observed peak was due to noise in the system, which is easily filtered by using a frequency window whose lower limitis higher. While such filtering is not possible with the Metravib system, it is with the ANL instrumentation. Another correlation peak showed a 9-ms differential, indicating a leak-to-sensor spacing of about $10 \mathrm{~m}$, if the empirically determined velocity of sound of $1100 \mathrm{~m} / \mathrm{s}$ is used. This result is consistent with the actual 12.8-m sensor-to-leak spacing, but the error is large (about 30\%).

The commercially available Metravib system is comparable in some respects to the ANL system but has limitations in several areas when used to locate steam leaks. The low- and high-frequency ranges should be more flexible to allow use of frequency windows such as 1-2, 2-4, and 3-6 kHz. The current Metravib system does not filter noise that the ANL system can; moreover, it requires a higher sampling rate and more sampling points. The Metravib system should also present the frequency spectrum for better characterization of noise sources, and it should have sensors that can tolerate steam pipe temperatures to allow direct contact with hot pipes.

\subsection{Leak Location with a Commercially Avallable Correlator under Field Conditions}

On September 20, 1991, personnel from Earl Ruble and Associates (Duluth, Minnesota) used a cross-correlation technique in attempting to locate three leaks in a Northern States Power (NPS) district heating system. These leaks were in pipes filled with hot water (condensate return line, $240^{\circ} \mathrm{F}, 150-200 \mathrm{psi}$ ). In the technique used, an acoustic sensor (with frequency response ranging from $100 \mathrm{~Hz}-2 \mathrm{kHz}$ ) was placed on one end of 
each of two waveguides. The other ends of the waveguides are put in contact with the pipe in two different manholes on either side of the suspected leak. Cables carried the electrical signals to the instrumentation for the location analysis. The first leak could be heard at two manholes 391 $\mathrm{ft}$ apart. However, no correlation peaks were evident that could be used to accurately locate the leak.

In past field studies, Ruble and Associates have discovered that pipelines in air (not buried), such as those suspended on wall brackets in a below-ground room, tend to "ring." They believe that this is because a sound wave traveling along the water causes the pipe to vibrate in an extremely minute manner, creating sound waves that are in the same frequency ranges as true leaks. In this case, the leak sound was extremely strong and it could have induced the pipe vibration that is described as ringing. This ringing could overwhelm the leak sound and prevent a successful cross-correlation analysis. Without the damping effect of surrounding soil or sand, ringing can occur in varying degrees, depending on all the factors at a particular location. In the case of the NSP condensate return line, the pipe is encased in a very-low-density insulating material designed to prevent heat loss but not to support a pipe securely. In such a situation, there is no known method of correlating a leak if the conditions are adequate to cause the ringing.

The second field trial was at a location said to be between transducer locations $600 \mathrm{ft}$ apart. The second pipeline is constructed just like the one described above. A weak leak sound was detected, but the correlation was virtually ideal. The signal-to-noise ratio was good and the leak location was specific. However is placed the leak at the "east" transducer. This means the leak was at that point or at a location farther away along the pipeline. From previous experience with this situation, the leak was either at the transducer location or was out of span (not between sensors) somewhere farther east of the "east" transducer location because there is no branch off the conderisate line. The test equipment was rearranged so that the presumed leak would lie between the old east transducer and the new transducer farther east. Again, an excellent leak pattern was obtained on the monitor. In this case, the leak was indicated to be $19 \mathrm{ft}$ west of what is now referred to as the new east transducer location. This was perplexing because that is where an excavation had been made a week earlier to repair a leak. Excavation later revealed that the source of the noise was indeed a 
leak from a temporary clamp about $19 \mathrm{ft}$ from the transducer location, as predicted. The leak rate was very small, also as predicted.

A question that must be answered is why it was possible to obtain a good correlator pattern on the monitor screen in the second case and not in the first. At present, we believe that the insulation in contact with the pipe provides enough damping to reduce the ringing and permit the leak sound to predominate in the second case (smaller leak). It is possible that the high pressures are important factors here as well.

At the third location, a strong leak was detected. However, pumps from a paper mill about $1200 \mathrm{ft}$ away caused interfering sounds and a correlation analysis was not possible.

\subsection{Leak Location with a Research-Quality Correlator under Laboratory and Fleld Conditions}

Laboratory tests were carried out at ANL with artificıal leaks under conditions that simulate the temperature and pressure of a steam distribution system $\left(180 \mathrm{psi}, 350^{\circ} \mathrm{F}\right)$. Laboratory-quality instrumentation (Spectral Dynamics Signal Analyzer SD375, Khrone-Hite filters. and Tektronix AM502 amplifiers) were employed. Laboratory testing was successful when sensors were placed directly on the pipe outer wall. Field tests with this system indicated that, in many situations, steam leaks in underground piping system can be located by acoustic techniques. However, application of the tested technology to underground piping is subject to limitations, chief of which is the presence of bellows that severely attenuate the acoustic wave generated by the leak. Where two acoustic sensors can be placed on bare pipe on either side of a leak, with no bellows intervening, it is possible to detect and locate a leak by cross-correlation analysis. Where manholes are separated $200 \mathrm{ft}$ or more, it should be possible to detect steam leaks with sensors placed on the pipe outer wall if the leak is large (i.e., significant vapor is visible at one or both manholes).

\subsection{Leak Location with an In-Stream Sensor}

Transducers or transducer/waveguide systems placed directly on the steam pipe outer wall may not be effective enough to locate leaks in long runs of DH piping or in runs with bellows between sensors. One possibility 
for circumventing the general problem of steam leak detection with externally mounted sensors is to insert an acoustic transducer inside the pipe to detect steam-propagated sound waves directly. The main purpose of the program being carried out at ANL in collaboration with NRG Thermal and Consolidated Edison is to develop an in-stream sensor for steam leak location.

We have carried out a brief evaluation of in-stream monitoring using a capacitance microphone to illustrate the potential for improvements in location capability. Cross-correlation analysis of signals from a gas leak in the ANL piping system suggests that in-stream monitors are more effective than sensors mounted on the pipe outer surface. The use of commercially available capacitance microphones or miniature hydrophones (e.g., Eruel and Kjaer model 8103) may not be viable for detection of steam-propagated sound because of the elevated temperature of the steam. Special hightemperature microphones (e.g., Endevco models 2510 or 8521-5M1) are designed for high-intensity applications (e.g., jet engine noise) and may not be sensitive enough for detection and location of steam leaks. The most promising sensor is one made of a piezoelectric material fixed in a tube about $1 / 2 \mathrm{in}$. in diameter and able to tolerate the elevated temperatures and pressures of a steam system. Such high-temperature microphones can be inserted without disturbing service, by means of a hot tap.

Conclusions

Several leak detection techniques are currently available for district heating and cooling systems. Application and effectiveness of each technique depend on the design and installation method of the DHC piping, location of the leak (in the jacket or the carrier pipe), system operating parameters, and knowledge of system layout and components. The most common systems used today are classified according to their principle of operation as follows: acoustic emission, infrared spectroscopy, tracer gas, and electrical.

While all of these techniques have been tried in one form or another, only acoustic leak detection has the potential for being the most effective for locating leaks. However, sensors placed directly on the pipe outer wall may not be effective enough for acoustical location of steam leaks in long runs of DHC piping. One way to circumvent the general problem of steam leak 
detection in buried pipe is to insert an acoustic transducer inside the pipe to detect steam-propagated sound waves directly.

A survey was undertaken as part of a joint program between the U.S Department of Energy and utilities involved with district heating and cooling. The purpose of the survey is to identify and characterize current practices for detecting and locating leaks in district heating systems; specifically steam systems. This information reflects district heating industry conditions, needs, and requirements and will assist ANL in the development of acoustic leak detection technology

\section{Acknowledgments}

The authors wish to thank M. Spurr for the survey data and W. Lawrence, R. Popper, and R. Carlson for their contributions to this project. 
1. D. S. Kupperman and D. E. Karvelas, Acoustic Leak Detection for District Heating Systems, Argonne National Laboratory Report ANL-87-60 (Feb. 1988).

2. K. E. Cooper, C. Marsh, and E. G. Segan, Evaluation of Techniques for Locating Leaks in Underground Heat Distribution Systems, U.S. Army Corps of Engineers, Construction Engineering Research Laboratory Technical Report M-86/16 (Aug. 1986).

3. D. S. Kupperman, T. N. Claytor, T. Mathieson, and D. Prine, Leak Detection Technology for Reactor Primary Systems, Nucl. Safety, 28:191 (April-June 1987).

4. J. Reason, Acoustic Leak Detection Provides Early Warning of Piping Failure, Power, 63 (Sept. 1987).

5. J. E. Coulter, T. P. Sherlock, and D. M. Stevens, Acoustic Emission Monitoring of Cracks in Fossil Fuel Boilers, Electric Power Research Institute Report EPRI CS-5264 (July 1987).

6. J. G. Dimmick and J. M. Cobb, Utrasonic Detection Cuts Valve Maintenance Costs, Power Eng. 35 (Aug. 1986).

7. D. O. Harris, R. G. Brown, D. Dedhis, and D. E. Leaver, Acoustic Emission Leak Detection and Location Systems Technology Review, Electric Power Research Institute Report EPRI NP-80-7-LD (Dec. 1980).

8. H. V. Fuchs, W. Frommhold, R. Poggemann, R. and P. Zenker, Acoustic Leak Location on District Heating Pipes, HLH, Heizung, Lüftung, Klimatechnik, Haustechnik, 42:1; Fraunhofer-Institut für Bauphysik, Stuttgart, and Energieversorgung Oberhausen AG, West Germany.

9. H. Schwarze, Computer-aided Measuring System for Automatic Monitoring of Pipe Networks and Leak Detection, Technisches Messen, 55(7-8): 279-285; Fachhochschule Bielfeld, Bielfeld, West Germany (1988). 
10. H. J. Micheel, Leakage Monitoring in Synthetic Jacket Pipes for District Heating Supply, Fernwaerme International, 16(6): 380-385, Salzgitter Elektronik GmbH, Kiel, West Germany (Nov-Dec 1987).

11. D. B. Chang, B. M. Pierce and I. Shih, Environmental Monitoring Technologies, SAE Technical Paper Series 910190, International Congress and Exposition, Detroit, Feb. 25-March 1, 1991.

12. H. Turtiainen, Leak Location in District Heating Networks Using Acoustical Correlation Techniques, Valtion Teknillinen Tutkimuskeskus, Espoo, Finland (1982).

13. H. Gransell and J. Ljungquist, In Situ Control of District Heating Networks, Annual Conference of the Int'l District Heating Assoc., (1985).

14. A. Jette, M. Norman, S. Milchael, J. C. Murphy, and J. G. Parker, Active Acoustic Detection of Leaks in Underground Natural Gas Distribution Lines, Materials Evaluation, 35(10): 90-96, 99 (Oct. 1977).

15. A. C. Eapen, R. L. Ajmera, S. M. Agashe, Pipeline Leak Location Using Radiotracer Technique, Bhabha Atomic Research Centre, Isotope Div.. Bombay, India (1983). 
Appendir A:

Survey Form and Introductory Remarks for Acoustic Leak Detection and Location 
44 
Argonne National Laboratory, under contract to the U.S. Department of Energy and several district heating utilities, is developing a system for detecting and locating district steam piping leaks using acoustic technology.

The objective of the project is to develop a highly accurate acoustic leak detection and location system so that excavation for repairs can be minimized. Based on previous work, it appears that for steam district heating an in-stream sensor, probably using a hot tap, will be required to achieve the desired accuracy (within several meters).

The system would involve the insertion of two transducers into the hot taps, without disrupting steam service. Transducers could be attached permanently, to be periodically monitored, or a pair of transducers, as part of a mobile unit, could be placed as needed at sites of interest. Signals from the transducers would be transmitted by wire or radio waves and would be processed by mobile computer equipment.

Argonne is now performing research necessary for development of a field-implementable prototype system. On behalf of Argonne, I'd like to talk with you about leak detection and location practices and experiences in your system so that the prototype system is developed with a full understanding of district heating industry needs and requirements. 
Nama of Systam

Contaot Name

Phone

1. Dtuturtibutiton syratam

1. Yaar oldast pipa Inataliad

3. Type of pipe inataliation

Box condudt

solid poux condult

Tunnal

Prafab condutt

Diract Buxial

Othar

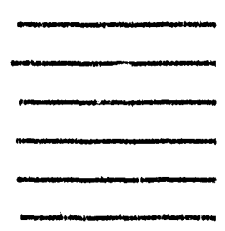

5. Intervals betwaen axpansion dervicas

6. Condensate return?

yas

7. Intervala batwaen manholas

B. Temperature and pressura

\section{B. Curanot rank Detreation}

1. What typar/locations of leaks are your blggeat problem?

Valves

rianges Expanalon devioes othar
Rollerw Welds

External corrosion

2. How are leaks detectud now?

3. How ara laks located? 
4. What to tha aocuraoy of youx looation methoda?

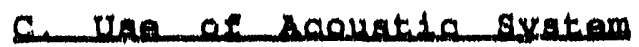

1. Would you ba intarastad in using an aooustia syatem ar dasaribad anilar? yas no

2. If not, why not?

3. What would Incrasso this systam' waefulnas to youp

4. Are you interastad in:
a ongoing syotem for monitoring, datection and lodation
b. A syatem for use as neoesonry to looata laaks detected through othex meano

5. Would you ba interated in fiald testing a prototypa systam?

yอง no 
49

Appendix B:

Notes From Survey 
51

LEAK DETECTION SURVEY

Name of system

Contact Name

Phone
Alabama Pone

Dale Dambeck

$205-226-1880$

A. Distribution system

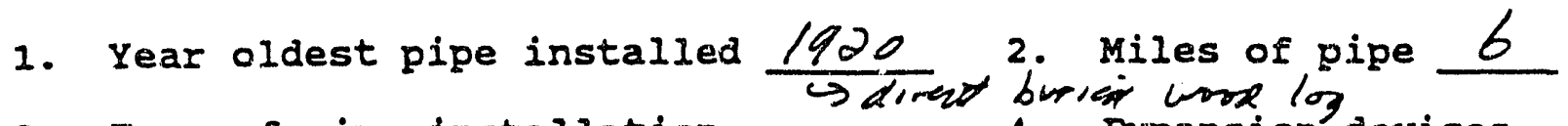

3. Type of pipe installation 4. Expansion devices

Box conduit (comate)

solid pour conduit Tunnel

Prefab conduit

Direct Burial

other
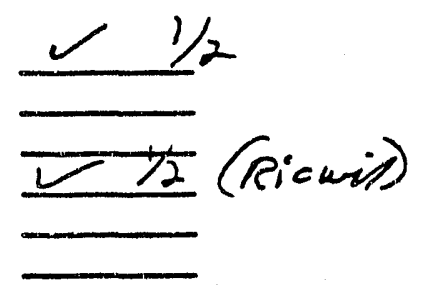

slip joints Bellows

Ball joint Exp. loop Other

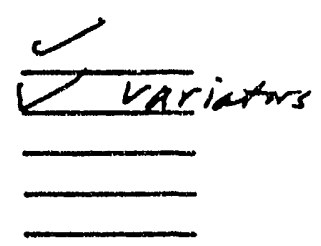

Connate box conduit - 2-21/2' by $2-21 / 2$ ' wielded soled pipe, on sou d poxkestat. La silicate banked to pipe. Ferra-cota half round on top.

Corrugate slip experwon joint. Ads co tor. on Ricwat pipe - ATS Slips.

$3-4 \cdot \operatorname{dog}$.

5. Intervals between expansion devices 200 feet average

6. Condensate return? yes no

7. Intervals between manholes 400 feet

8. Temperature and pressure 366-370 $150 \mathrm{psi}$ (HP steam) Saturation

psi (LP steam)

psi (hot water)

B. Current Leak Detection

1. What types/locations of leaks are your biggest problem?

Valves

Welds

Expansion devices other - Traps
Rollers

Flanges

External corrosion

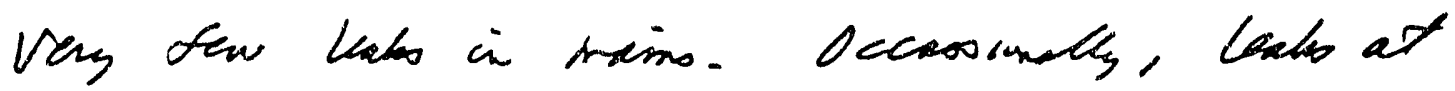
xp. join, especially corrugated ones.

most of the lakes are at be threaded

traps tithing. 
2. How are leaks detected now?

Visid6 otem

3. How are leaks located?

Usuelly of mankols (where all fittings we)

Of noo, weer street to loust. Oig wor fittings

Tried a hend hata sonei teootes - nb lucke.

4. What is the accuracy of your location methods?

wowks prets well. Hit ut on 1six dis 75-80\%

$\rightarrow$ time. Hit on dre hole $20-25 \%$ of dimo.

c. Use of Acoustic system

1. Would you be interested in using an acoustic system as described earlier? yes ᄂ no

2. If not, why not?

Hot tap instrowes 2 more leak opporanisis. lawerge bits that bug a probkn.

3. What would increase this system's usefulness to you?

4. Are you interested in:

a. ongoing system for monitoring, detection and location

b. A system for use as necessary to locate leaks detected through other means

5. Would you be interested in field testing a prototype system? yes no 


\section{IEAX DETECTION BORVEY}

Name of System Beldinere Themet

Contact Name

$$
\frac{\text { Pnen boor ner. }}{301-625-2222}
$$

Phone

A. Distribution system

1. Year oldest pipe installed

3. Type of pipe installation

Box conduit comat. Solid pour conduit munnel

Prefab conduit

Direct Burial

Other

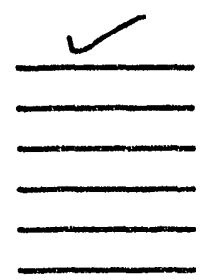

2. Miles of pipe $/ 5$

4. Expansion devices

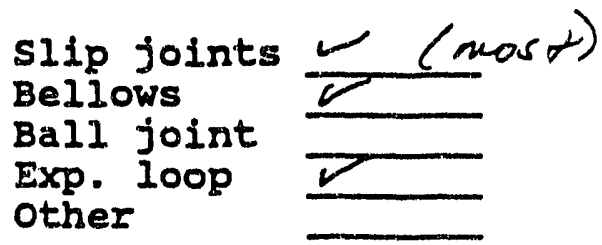

welded oted

5. Intervals between expansion devices $\simeq 200$ feet

6. Condensate return? yes __ no

7. Intervals between manholes 225 feet arenge

$$
350 \text { mantoles } 150 \text { tiaps }
$$

8. Temperature and pressure 375 F 160-180 psi (HP steam) 270
$F$

B. Current Leak Detection

1. What types/locations of leaks are your biggest problem?

Valves

Welds

Expansion devices

other Service $T$

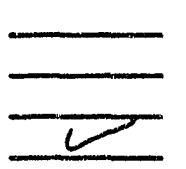

Rollers

Flanges

External corrosion

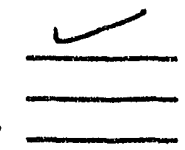

Late problem \& w/ LP sysoten 
2. How are leaks detected now?

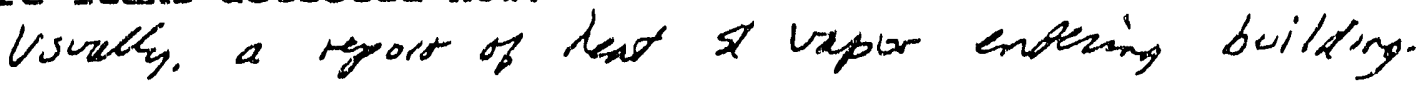

Intrared Tyone didx't work well, specially whan. theris a crach in conkwit.

3. How are leaks located? Weath Aroustie system. Buyght 4 yeass ago for $\sim 8 \% 000.3-y^{\prime \prime}$ dierrete pecpor placea on pavemant. Movo pesptor 24 " et a Xime. lave a stall perom who's goox ete thio. Wrarko prets well bur a twins lookeri to imprave.

4. What is the accuracy of your location methods? within $4-5$ '

c. Use of Acoustic System

1. Would you be interested in using an acoustic system as described earlier? yes no

2. If not, why not?

3. What would increase this system's usefulness to you?

$$
\text { Miniaize labor cost. }
$$

4. Are you interested in:

ongoing system for monitoring, detection and location

b. A system for use as necessary to locate leaks detected through other means

5. Would you be interested in field testing a prototype system? yes no 
55

I EAR DETECTION SURVEY

Name of system Alabama Pone Contact Name Phone Dale Dumber $205-226-1880$

A. Distribution System

1. Year oldest pipe installed $\frac{1920}{9 d i n t}$ bricoles of pipe 6

3. Type of pipe installation Box conduit (conc)
Solid pour conduit $=1 / 2$
Tunnel
Prefab conduit
Direct Burial
Other
4. Expansion devices

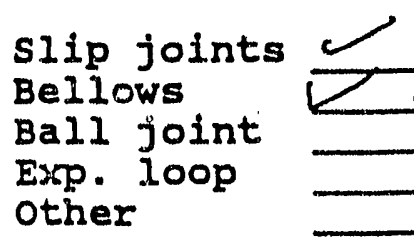

Conduct box conduit - 2-21/2' by $2-21 / 2$ ' welded soled pipe, on soled poxkestat. Ca silicate banked to pipe. Ferra-cobs hall rune on tho.

Corrugate slip expansion joint. Ads co toe. on ficus pipe - RTS stipe. $3-4 \cdot \operatorname{deg}$.

5. Intervals between expansion devices 200 feet avar

6. Condensate return? yes $\longleftarrow$ no

7. Intervals between manholes 400 feet

8. Temperature and pressure 366-370 F $150 \mathrm{psi}$ (HP steam) $\begin{array}{lll}\text { Satratar } & =F=\text { psi } & \text { (LP steam) } \\ \text { (hot water) }\end{array}$

B. Current Leak Detection

1. What types/locations of leaks are your biggest problem?

Valves Welds

Expansion devices other - Traps
Rollers

Flanges

External corrosion

very few lake in trims. Occaosunally, labs at top. joints, especially corrugate r ones.

most of the lake are at the threaded

trap citrins. 
2. How are leaks detected now?

Hiside otem

3. How are leaks located?

Usudly at Mankols (whene oll firtings we)

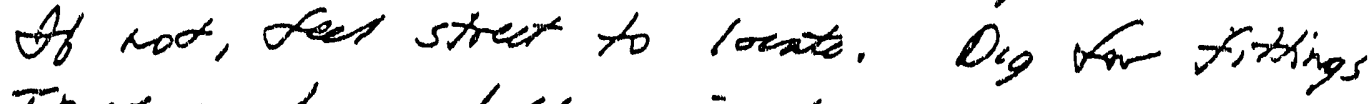

Tries a luna hat soniz teotes - No luck.

4. What is the accuracy of your location methods?

Wrows prets well. lit it on 15x chy 75-80\%

0 time. Hiti on ow hole $20-25 \%$ of time.

\section{c. Use of Acoustic System}

1. Would you be interested in using an acoustic system as described earlier? yes L no

2. If not, why not?

Hot tho introtwes of more lack opporanitio. lutenge wist that bug a probkn.

3. What would increase this system's usefulness to you?

4. Are you interested in:

a. Ongoing system for monitoring, detection and location

b. A system for use as necessary to locate leaks deterted through other means

5. Would you be interested in field testing a prototype system?

yes no 
57

LEAK DETECTION SURVEY

Name of system Boston Thermel

Contact Name

$\frac{\text { Al en Murphy - }}{617-482-1550}$

Phone

A. Distribution system

A. Mas $\alpha$

1. Year oldest pipe installed 11305 2. Miles of pipe 22

3. Type of pipe installation

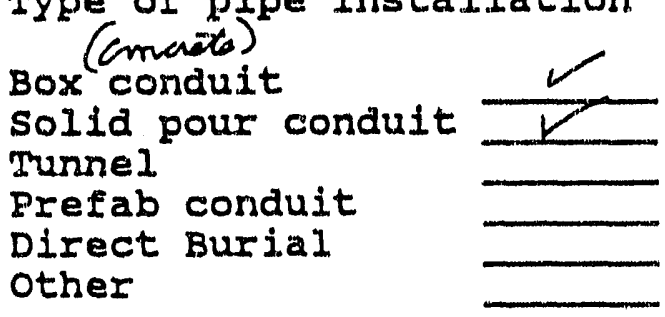

4. Expansion devices

slip joints Bellows

Ball joint

Exp. loop other

Carton sated pipe 6-24"

$\sim 10^{\prime}$ dorp

1150 Bellows - divas burial

5. Intervals between expansion devices 25 feet

6. Condensate return? yes

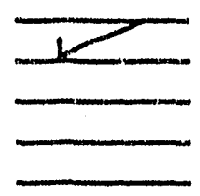

7. Intervals between manholes 465 feet evener 250. max holes

180-t80 cot plow wast

8. Temperature and pressure

F

$120 \mathrm{psi}$

(BRP steam) to condom

psi (LP steam)

psi (hot water)

B. Current Leak Detection

1. What types/locations of leaks are your biggest problem?

Valves

Welds

Expansion devices other

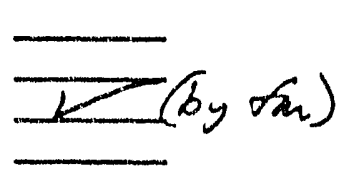

Rollers

Flanges

External corrosion

lose about If bellows each bean, phis serval other lacks. Very few lakes in pipe is self. 
2. How are leaks detected now? Nisibl vapor. Hrwevies, the is a high wates thble, on vapor doenofe ahoays mean a laate. Have in acoustic device - tried. Dro 2

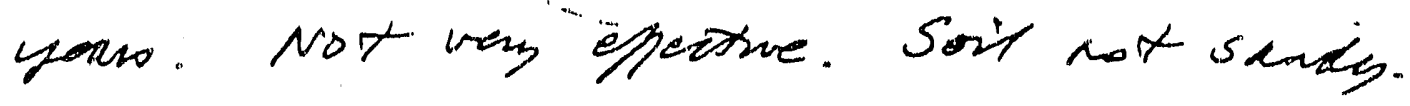
Thid inora-red - not vens effecture

3. How are leaks located?

Use drawins, plus the above, to locate.

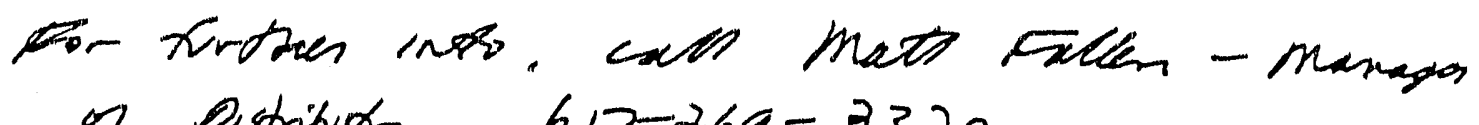
9 Distributon 617-269-3320

4. What is the accuracy of your location methods?

\section{c. Use of Accustic System}

1. Would you be interested in using an acoustic system as described earlier? ᄂ yes no

2. If not, why not? pornos" woulduit wend to do hot tags. Alare is olathon

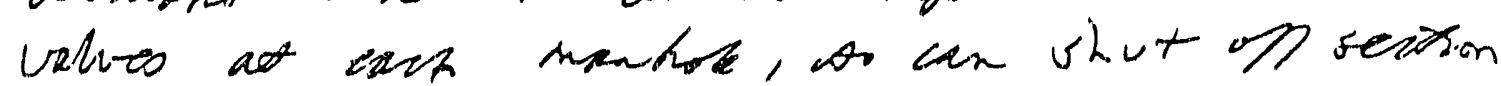
to wreld in thp.

3. What would increase this system's usefulness to you?

4. Are you interested in:

a. Ongoing system for monitoring, detection and location 0 A system for use as necessary to locate leaks detected through other means

5. Would you be interested in field testing a prototype system? yes no 
59

TEAT DETECTION SURVEY

Name of system Canal tat Distribution - Vancouva, B,C. Contact Name Vim Bemean, Provider Phone 604-688-9584

A. Distribution System

1. Year oldest pipe installed 1969

3. Type of pipe installation

Box conduit

Solid pour conduit Tunnel

Prefab conduit

Direct Burial

other
2. Miles of pipe

4. Expansion devices

slip joints $\measuredangle$ low n pipes

Bellows joint

Exp. loop other

waled in vaults.

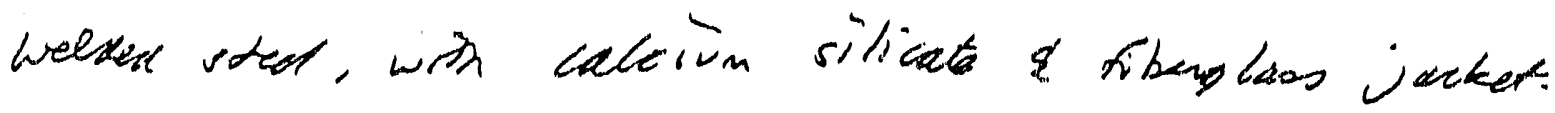

5. Intervals between expansion devices feet

6. Condensate return? yes no

7. Intervals between manholes set

8. Temperature and pressure

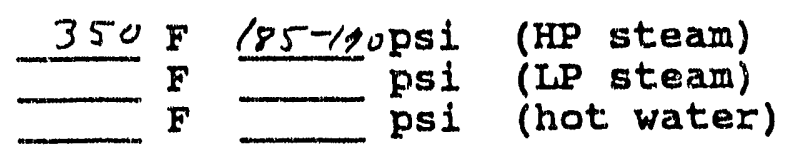

B. Current Leak Detection

1. What types/locations of leaks are your biggest problem?

Valves Welds

Expansion devices other
Rollers

Flanges

External corrosion

leakage is not a problem. Gassing no corrosion. Attribute this to good wats

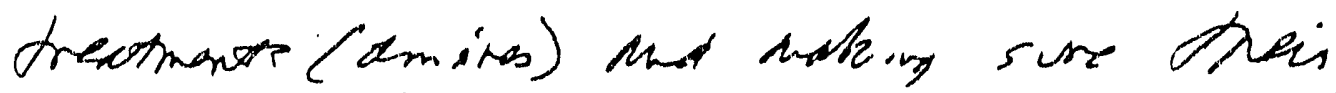
pipes ane locates above the watch utility 
2. How are leaks detected now?

3. How are leaks located?

4. What is the accuracy of your location methods?

C. Use of Acoustic system

1. Would you be interested in using an acoustic systein as described earlier? yos Lno

2. If not, why not?

$$
\text { tiano enerif a probiom }
$$

3. What would increase this system's usefulness to you?

4. Are you interested in:

a. Ongoing system for monitoring, detection and location

b. A system for use as necessary to locate leaks detected through other means

5. Would you be interested in fleld testing a prototype system? yes _ no 
IFAX DETECTION BURVEY

Name of system Clevelen Therror

Contact Name

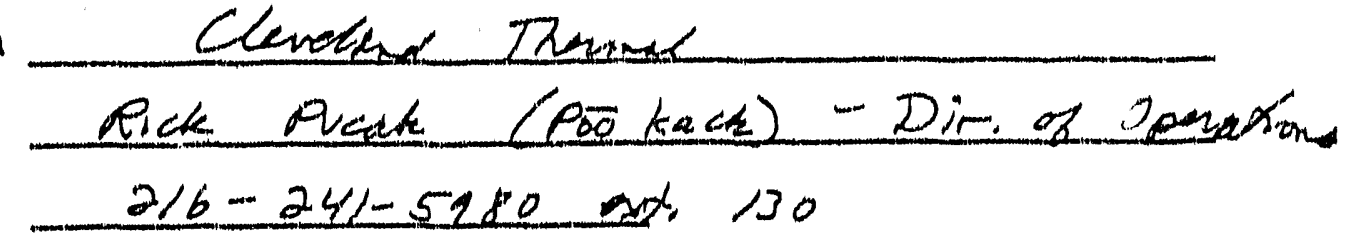

Phone

2. Miles of pipe lQ

4. Expansion devices

3. Type of pipe instaliation

Box condult comest solid pour conduit Tunnel

Prefab condult

Direct Burial

other

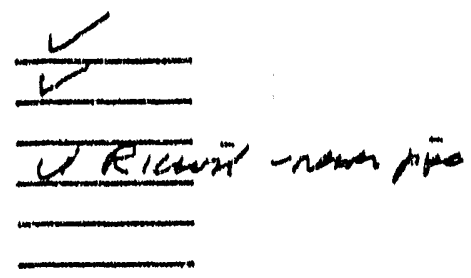

silp foints $N H P$ Bellows "rarlarum" Ball. Joint: Exp. Loop other

A160 axpersually, preasurizar deliows. inew ctorign tor $L \rho \sin s+4 n$

50 r reinators

5. Intervals between expansion devices $\frac{200}{200-300}$ feet Ep belibus

6. Condensate return? yes no

7. Intervals between manholes 100 feet and whoner thenó a valme 450 hanhurte.

8. Temperature and pressure $365 \mathrm{~F} 150 \mathrm{psi}$ (HP steam) $\frac{365}{260} \mathrm{~F} 20-27 \mathrm{psi}$ (LP steam) psi (hot water)

\section{B. Curfent Leak Detection}

1. What types/locations of leaks are your biggest: problem?

Valves

Welds

Expansion davices other

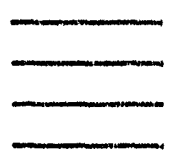

Rollers

Flanges

External corrosion

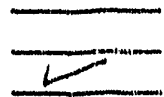

$(90 \%)$

LP sysotem io the problan. top ok. 
2. How are leaks detected now?

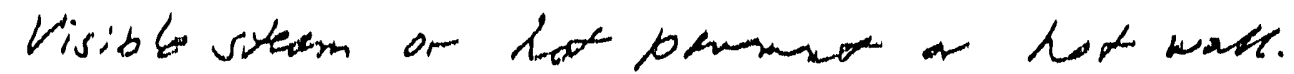

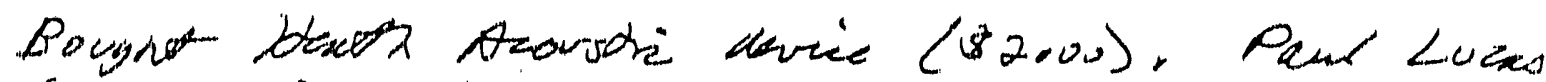

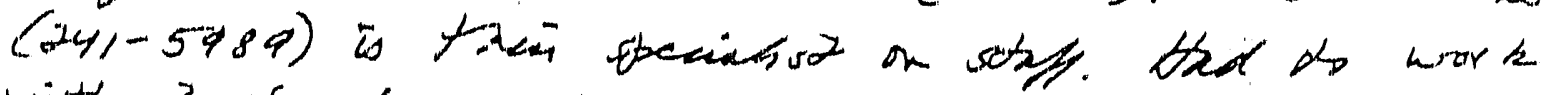
wiph it to devolog "gow ear." Now works waj well. sand's soib - sarx dranometer well. Widz sidys

3. How are leaks located? of choorit wrork, Dickif work a Baroton - possibly due to soita.

Must use $2-5$ Am.

4. What is the accuracy of your location methods?

$$
\text { Q0\% accuracy }
$$

c. Use of Acoustic system

1. Would you be interested in using an gooustic system as described earlier? yes no

2. If not, why not? thposy with curront system.

3. What would increase this system's usefulness to you?

4. Are you interested in:

a. Ongoing system for monitoring, detection and location

b. A system for use as necessary to locate leaks detected through other means

5. Would you be interested in field testing a prototype system? yes no 


\section{IEAX DETECTION BURVEY}

Name of system

Contact Name

Phone

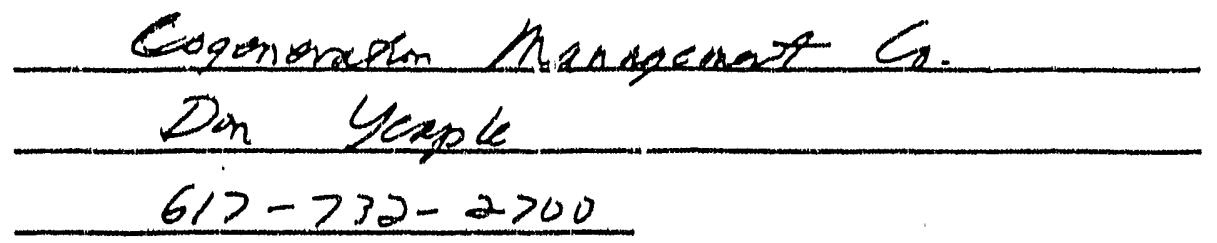

\section{A. Distribution System}

1. Year oldest pipe installed $(976$

2. Miles of pipe $/ 1 / 2$

3. Type of pipe installation

4. Expansion devices

Box conduit

solid powr conduit

Tunnel

Prefab conduit

Direct Burial

other

silp joints

Bellows

Ball joint

Exp. loop

other

Woth pipe in Xurelo, Calle ane obvious.

All chotomso we hospitite. 900,000 165/hr steam cop.

ritgen plant 5 botors. 2 are hat rewary boiless (wose dicod exhanot)

challed water 24,000 two, 5 centrixigal, 2 ebsorber

5. Intervals between expansion devices __feet

6. Condensate return? yes no

7. Intervals between manholes feet

8. Temperature and pressure

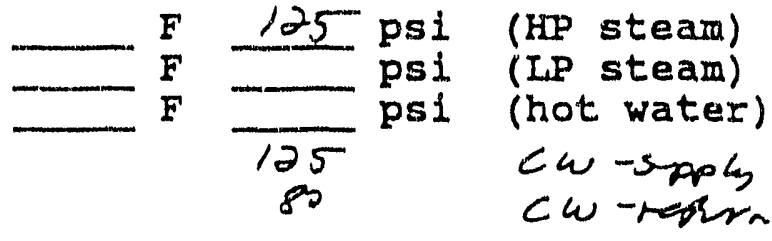

B. Current Leak Detection

1. What types/locations of leaks are your biggest problem?

Valves

Welds

Expansion devices

other
Rollers

Flanges

External corrosion 
2. How are leaks detect-d now?

3. How are leaks located?

4. What is the accuracy of your location methods?

\section{c. Use of Acoustic System}

1. Would you be interested in using an acoustic system as described earlier? yes no

z. If not, why not?

3. What would increase this system's usefulness to you?

4. Are you interested in:

a. Ongoing system for monitoring, detection and location

b. A system for use as necessary to locate leaks detected through other means

5. Would you be interested in field testing a prototype system? yes $\quad$ no 
LEAX DETECTION BORVRY

Name of System Conered stem

Contact Name

Phone

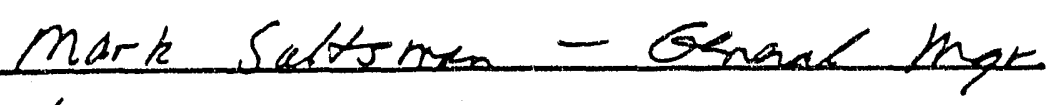
$603-224-1461$

\section{A. Distribution system}

1. Year oldest pipe installed 1930 's 2. Miles of pipe $\sim 8$

3. Type of pipe installation

4. Expansion devices

Box conduit Solid pour conduit Tunnel Prefab conduit Direct Burial other

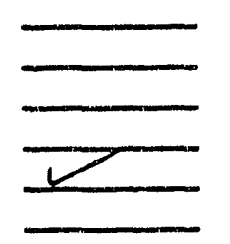
sip joints Bellows Ball joint Exp. loop other

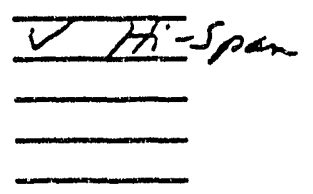

helded stat. "Wickalute" powdued pour insuhtsonhaders like concret 2-6'deph, y' arange. Fandes sanky soit.

5. Intervals between expansion devices _L feet hot sm

6. Condensate return? $\zeta_{\text {Gon ore line }}$ yes no

7. Intervals between manholes feet ar sos pacing

8. Temperature and pressure $370 \mathrm{~F} 165 \mathrm{psi}$ (HP steam) $\begin{array}{lll}\text { Saturat } & =-\mathrm{p}=\text { psi } & \text { (LP steam) } \\ \text { (hot water) }\end{array}$

B. Current Leak Detection

I. What types/locations of leaks are your biggest problem?

Valves

Welds

Expansion devices other
Rollers

Flanges

External corrosion 
66

2. How are leaks detected now?

Visible steam or water in manhole, ar Lot spot

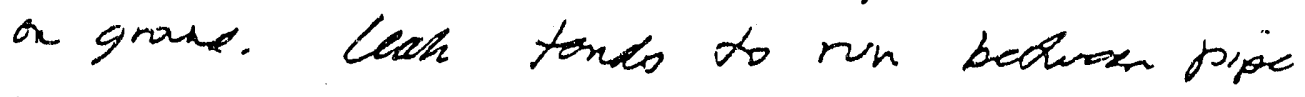
and insulation - w os ow t ito manhole.

lento rent a big problem.

3. How are leaks located?

Q ob your Wats Bot. brings. thai e acoustic aerie- with Dept.

works well. Heath Agraseape. Dives contact on $603-225-8693$ foremen or on valves. Bought 10 sean azo. Price

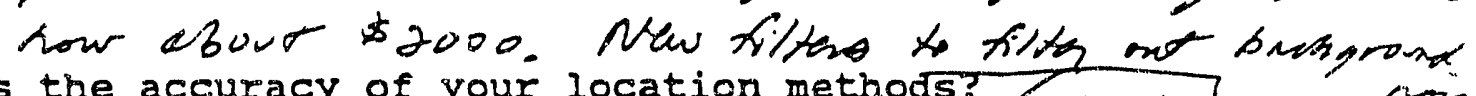
4. What is the accuracy of your location methods? Ford. Cordon.

c. Use of Acoustic system.

1. Would you be interested in using an acoustic system as described earlier? yes no

2. If not, why not?

3. What would increase this system's usefulness to you?

4. Are you interested in:

a. Ongoing system for monitoring, detection and location

b. A system for use as necessary to locate leaks detected through other means

5. Would you be interested in field testing a prototype system? yes no

$\$$ Hers davies not useful on plastic pipe las is used in with sites) and loon work well on soil (comparer to panamas). Sometimes use a bat do content cans $\backslash$ leaksurv

the pipe. 


\section{LEAK DETECTION 8URVEY}

Name of system $\frac{\text { Consoliduted Exison }}{\text { Tons Lodmact Name }}$
Phone

A. Distribution System

1. Year oldest pipe installed

3. Type of pipe installation

Box conduit

Solid pour conduit

Tunnel pije

conduit

Direct Burial

other
2. Miles of pipe

4. Expansion devices

slip joints

Bellows

Ball joint

Exp. loop

other

S Typer of outes pipe vaves

Bepore 1445 - Finged pipe. ( $550 \%$ of trital)

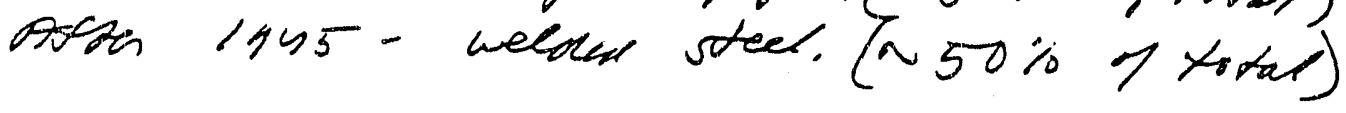

5. Intervals between expansion devices $30-200-(100) \rightarrow 5 / 40$ joms

6 . Condensate return?

yes no

7. Intervals between manholes $\simeq 500$ feet be pen blow

8. Temperature and pressure

$$
\begin{array}{lll}
F & 200 \text { psi } & \text { (HP steam) } \\
F & \text { psi } & \text { (IP steam) } \\
F & \text { psi } & \text { (hot water) }
\end{array}
$$

B. Current Leak Detection

1. What types/locations of leaks are your biggest problem?

Valves

Welds

Expansion devices

other
Rollers

Flanges

External corrosion

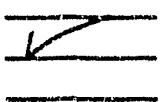


68

2. How are leaks detected now? - Visible stem

- Brood paramo

- Cusotaner complaint

3. How are leaks located?

1. Narrow lozxton to between manholes

2. Feel undone hotter

3. Chest rene re treason of Sibling

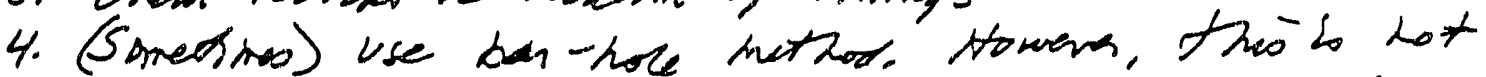

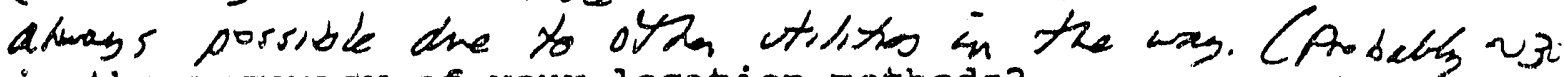
4. What is the accuracy of your location methods? of sg stay), 1 bs p, Not do gout is he wants. Probed $\sim 90 \%$ ben -hollis is a Softy concern.

c. Use of Acoustic System 1. Would you be interested in fusing an acoustic system as
described earlier?

2. If not, why not? Convene to ret tor hot tap. Daryorsey

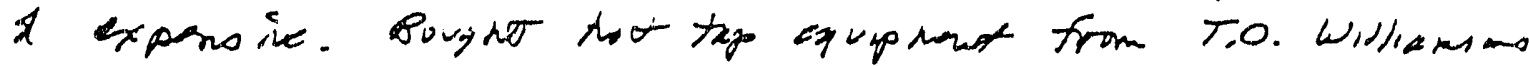
in Texas abut 10 expo age. Generally used tor 3-6" taps.

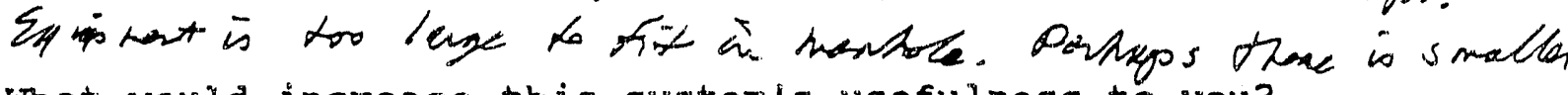
3. What would increase this system "s usefulness to you?

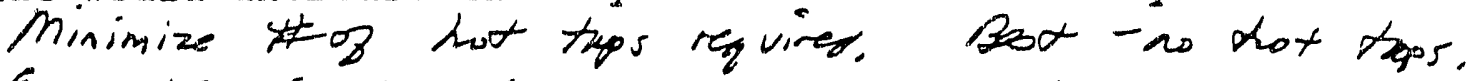

Excavating or tap defeats purpose. Typ introduces a now 4. Are you interested in: leah potwrid.

a. ongoing system for monitoring, detection and location

b. A system for use as necessary to locate leaks detected through other means

5. Would you be interested in field testing a prototype system?

yes no

$\rightarrow$ equipment araitabl how tor small hot tops. Fours about thous per too tap booed on this cmslleaksurv Expense: escavalon \$3000 $\$ \$ 1000$ labor tor the Ca men tor Ides et $\$ 30$ /tom) 
69

LEAK DETECTION SURVEY

Name of system

Contact Name

Phone
Dayton pow n 8 lis it

Hear Routzobn

$5 / 3-2272481$

A. Distribution System

1. Year oldest pipe installed 1902

3. Type of pipe installation

Box conduit
Solid pour conduit $10-15 \%$ Tunnel

Prefab conduit

Direct Burial

other cook lon
2. Miles of pipe 15

4. Expansion devices

slip joints Bellows

Ball joint

Exp. loop

other

Pipes 3-4' dog. Prangs 51/2'

5. Intervals between expansion devices 50-100 feet

6. Condensate return? yes no

7. Intervals between manholes los feet ave ge

8. Temperature and pressure $384 \mathrm{~F} 190 \mathrm{psi}$ (mp stem)

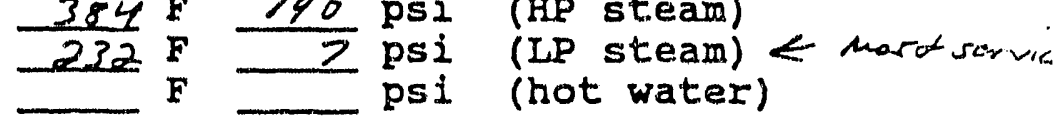

B. Current Leak Detection

1. What types/locations of leaks are your biggest problem?

Valves

Welds

Expansion devices other
Rollers

Flanges

External corrosion

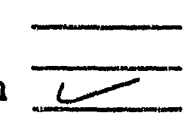

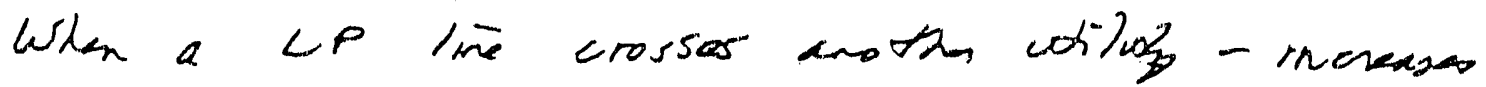
leah potential.

the a 4-man crew whose Klltime job is lovely $\$$ fixing lake 
2. How are leaks detected now?

$$
\text { Regular inspection, risible sotam. }
$$

3. How are leaks located?

Coneuly, ve intra-red gen (bough 5-6 yexpogo) Sometimo use a tomp. probe. Also, on raing day, can see dry spot. See adxiotonal intormation in Bapandix.

4. What is the accuracy of your location methods?

$$
\text { Finily youx }
$$

\section{c. Use of Acoustic System}

1. Would you be interested in using an acoustic system as described earlier? yes

rno

2. If not, why not?

Satisoles with umber approack

3. What would increase this system's usefulness to you?

4. Are you interested in:

a. ongoing system for monitoring, detection and location

b. A system for use as necessary to locate leaks detected through other means

5. Would you be interested in field testing a prototype system? yes no 
71

LEAK DETECTION SURVEY

Name of system

Contact Name

Phone
Detroit Epson

Terry Schumpeter

$3 / 3-23>5290$

A. Distribution system

1. Year oldest pipe installed 190.5

3. Type of pipe installation

older Box conduit

new solid pour conduit Tunnel

Prefab conduit

Direct Burial

other
2. Miles of pipe 50

4. Expansion devices

slip joints $\simeq$ C in rand ole.

Bellows

Ball joint

Exp. loop

other

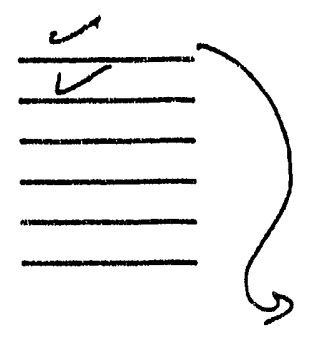

$8-101$ generally

5. Intervals between expansion devices You-50 feet gnarly

6. Condensate return? yes $\checkmark$ no Except abut 5 milo

7. Intervals between manholes Yyo-50u feet dwerago

of tunnel

8. Temperature and pressure 338-352 F 100-125 psi (HP steam) Saturated

$207-218 \mathrm{~F}$

$40-50$ psi

(I,P steam)

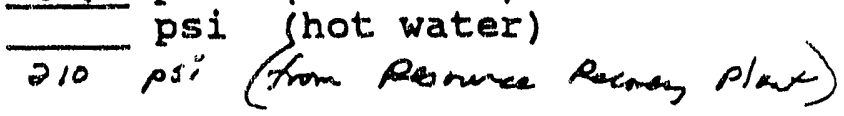

B. Current Leak Detection

1. What types/locations of leaks are your biggest problem?

Valves

Welds

Expansion devices other
Rollers

Flanges

External corrosion (worst)

Fix about yo lealos/yex.

Spend $\$ 10-15 k$ per excavation

Spend about \$s million leas on leaks. 
2. How are leaks detected now? Vissble sotem

3. How are leaks located?

Sonic dotor. Dritl hole in paremet. Pit probe down to tor of concrete conluits Eresy toot or so.

4. What is the accuracy of your location methods?

$$
\text { bit or miss }
$$

c. Use of Acoustic system

1. Would you be interested in asing an acoustic system as described earlier? yes no

2. If not, why not?

3. What would increase this system's usefulness to you?

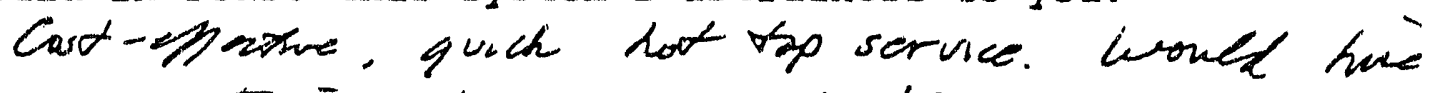

4. Are you interested in: stop wont do than.

a. Ongoing system for monitoring, detection and location

6. A system for use as necessary to locate leaks detected through other means

5. Would/you be interested in field testing a prototype system? yes no 
LEAK DETECTION BURVEY

Name of system

Contact Name

District rong, st Peul Exce.

Phone

Ray Serimuit, Discributon Suprindtakd $6 / 2-292-8155$

\section{A. Distribution system}

1. Year oldest pipe installed 1983

2. Miles of pipe 20

3. Type of pipe installation

4. Expansion devices

Box conduit

Solid pour conduit

Tunnel

Prefab conduit

Direct Burial

other

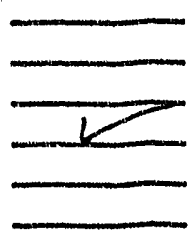

silp joints Bellows

Ball joint

Exp. loop

other

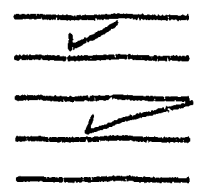

$$
2-4^{\prime} \cos y+x
$$

5. Intervals between expansion devices

feet variz

6. Condensate return? yes

no

7. Intervals between manholes 350 feet varies

8. Temperature and pressure

$$
\text { and pressure }
$$

B. Current Leak Detection

psi (HP steam) F 18 p $\rightarrow 150$ psi (LP steam) sypply $\Rightarrow$ rexirn

1. What types/locations of leaks are your biggest problem?

Valves

Welds

Expansion devices Other
Rollers

Flanges

External corrosion

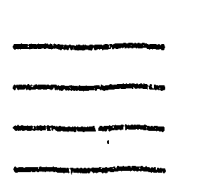

No leass 
2. How are leaks detected now?

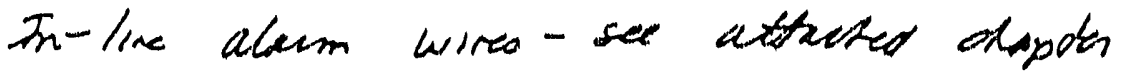

$$
\begin{aligned}
& \text { from sind claxiyn rpord. (in Apportix) }
\end{aligned}
$$

3. How are leaks located?

4. What is the accuracy of your location methods?

c. Use of Acoustic System

1. Would you be interested in using an acoustic system as described earlier? yes no

2. If not, why not?

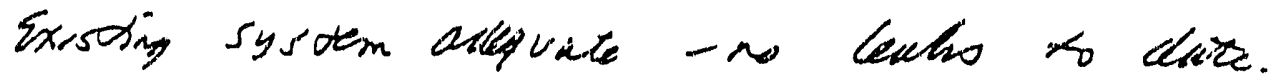

3. What would increase this system's usefulness to you?

4. Are you interested in:

a. Ongoing system for monitoring, detection and location

b. A system for use as necessary to locate leaks detected through other means

5. Would you be interested in field testing a prototype system?

_yes no 
LEAX DETECTION BURVEY

Name of systiem Eneny Notworko fue - thertoger

Contact Name

Phone

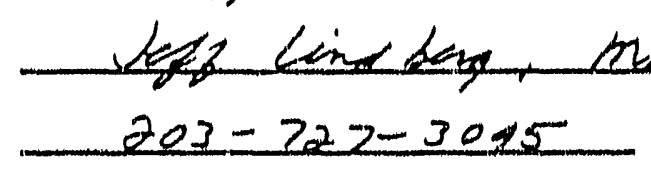

A. Distribution system

1. Year oldest pipe installed 1962

3. Type of pipe installation

Box conduit

Solld pour conduit

Turnel

Prefab condult

Direct Burial

other

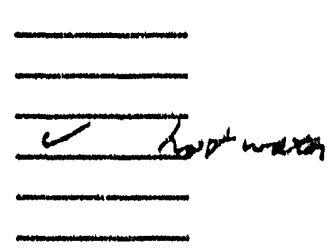

6 matis suteren.

2. Miles of pipe $35-40$ mile. b-r nltes cheis

4. Expansion devices wata

Sttam to pope witain pipe w/ enuvlus soace.

Sorre of the chitled wate 7 sotem pips is 30 yono old.

$2-8^{\prime}$ degp. 3-y' andoger.

5. Intervals between expansion devices 100 feet

6 . Condensate return? yes

sifp joints

Bellows

Ball joint

Exp. loop

other

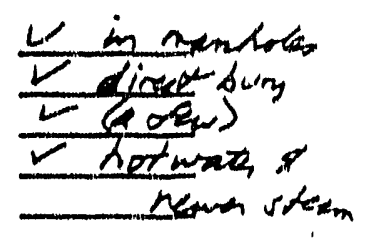

7. Intervals between manholes 500-1000 feet

8. Temperature and pressure

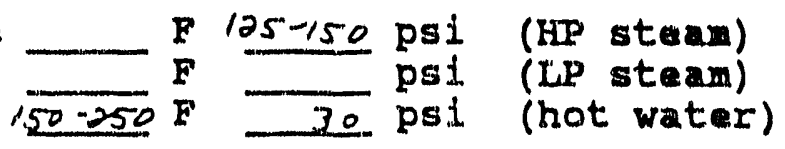

B. Current Leak Detection

1. What types/locations of leaks are your biggest problem?

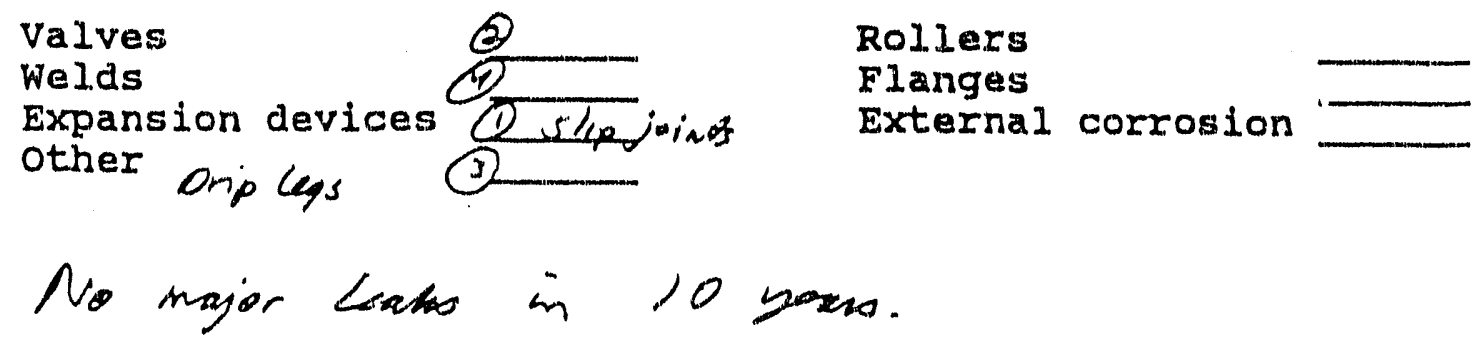


2. How are leaks detected now?

Stam - visible sotwom

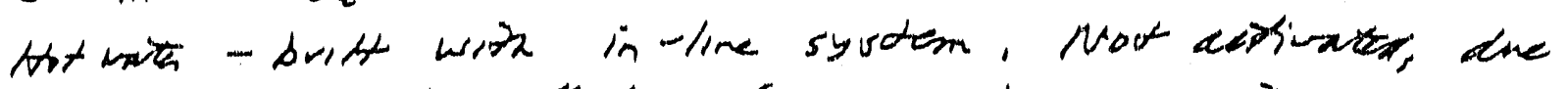

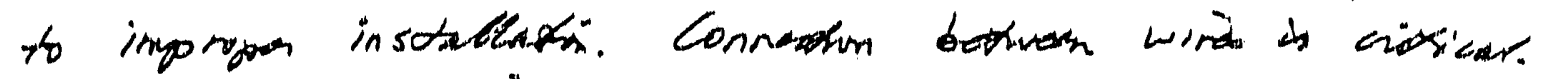
N. leck phoblom in rot wates or chelles wrata lines.

3. How are leaks located?

steerm pipe late lozxtion is a problom.

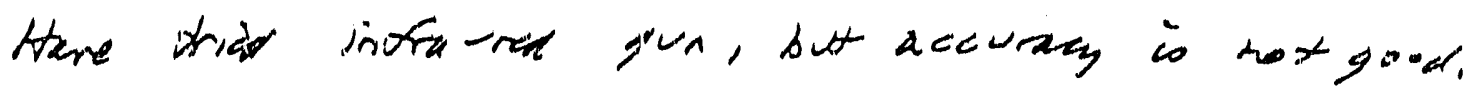

4. What is the accuracy of your location methods?

C. Use of Acoustic system

1. Would you be interested in using an acoustio system as described earlier? yes no

2. If not, why not? Althovgh lass anje a big prodlem.

3. What would increase this system's usefulness to you?

4. Are you interested in:

a. Ongoing system for monitoring, detection and location

b. A system for use as necessary to locate leaks detected trirough other means

5. Would you be interested in field testing a prototype system?

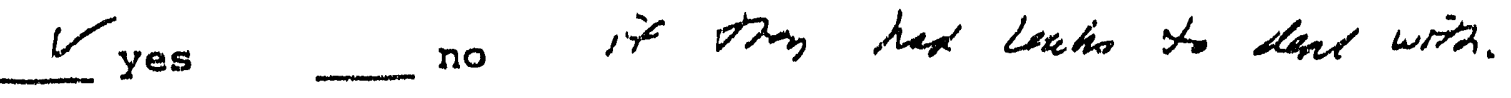


$8 / 13$

77

LENT. DETECTION SURVEY

Name of system Energy Systems Company - Orate contact Name Dave Woods Phone $402-346-1066$

A. Distribution system

1. Year oldest pipe installed 1967

3. Type of pipe installation

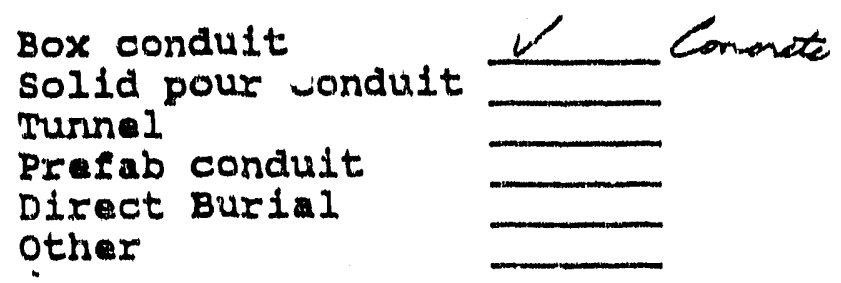

2. Miles of pipe

4. Expansion devices

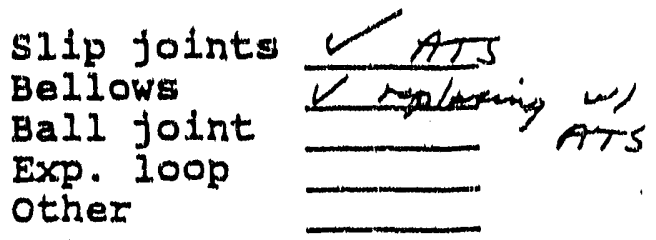

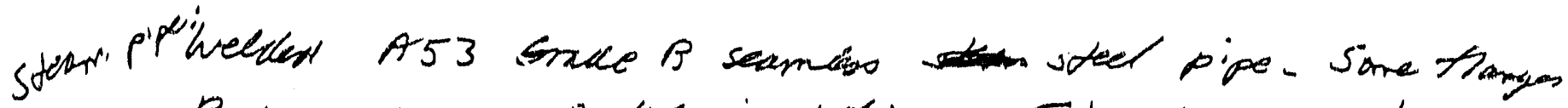
Rout wool an pauline insulation w/ Fiberglas e ven top.

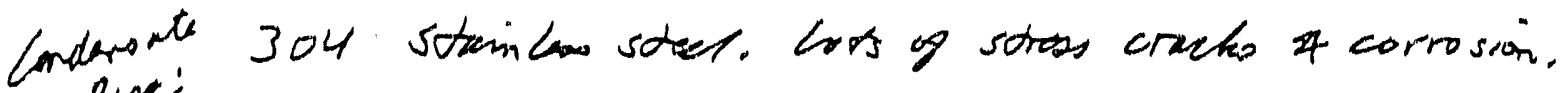
pip:

Dram pipe insulates in conduit. 3/s"dionets.

5. Intervals between expansion devices feet

6. Condensate return? yes no

7. Intervals between manholes $200-300$ feet

8. Temperature and pressure $400 \mathrm{~F} 125 \mathrm{psi}$ (HP steam) psi (LP stearin) psi (hot water)

B. current Leak Detection

shoo crutlese watt

1. What types/locations of leaks are your biggest problem?

Valves

Welds

Expansion devices other
Rollers

Flanges

External corrosion

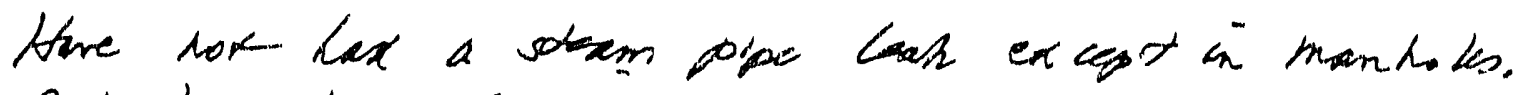

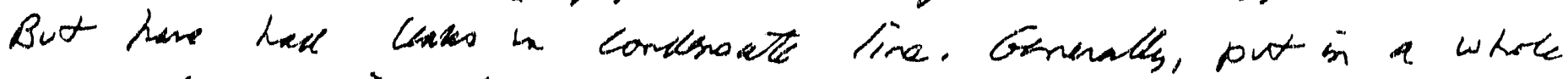
hew slave inside the exustay condensate pipe.

Have a called wets system - but is not a leak problem. 
2. How are leaks detected now?

- livato in maríco

- rapor in maxhas nee wats lios bottom op viex pio

3. How are leaks located? As noot dbone, usvelly juix replace wher

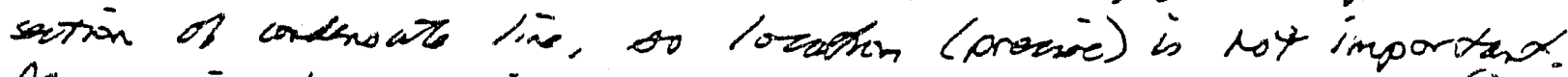

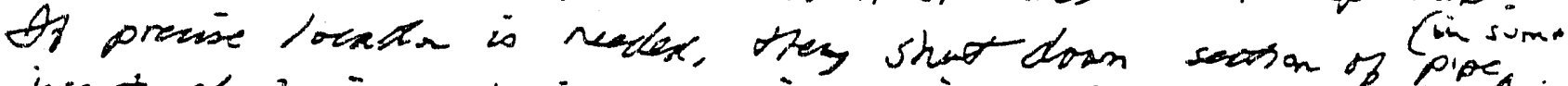

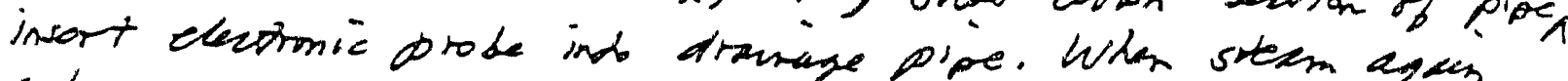

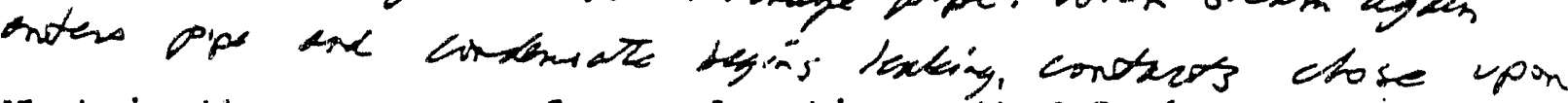

4. What is the accuracy of your location methods? Acanteng writs

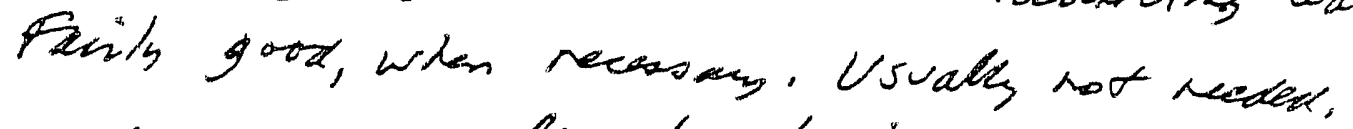

c. Use of Acoustic system the to stering of whic sezxor.

1. Would you be interested in using an acoustic system as described earlier? __ yes no

2. If not, why not? labo rally went a problem, of wow condenste lines beisin to leak, he ofect oraz *

3. What would increase this system's usefulness to you?

4. Are you interested in:

a. Ongoing system for monitoring, detection and location

b. A system for use as necessary to locate leaks detected. through other means

5. Would you be interested in field testing a prototype sy,tem? yes no

cmslleaksurv

3 37 . 
79

LEAK DETECTION SURVEY

Name of System

Contact Name

Phone
Eugene Wat \& Slachi Bear

Dennis Ox y

$503-484-2411$

A. Distribution system

1. Year oldest pipe installed $/ 9 / /$

3. Type of pipe installation

Box conduit
Solid pour conduit
Tunnel
Prefab conduit
Direct Burial
Other
(Abate Grove)
$350-400$ milton $/$ bs/yon sales

Pipes $2-15, \operatorname{leg}$
2. Miles of pipe 8.5

4. Expansion devices

slip joints Bellows

Ball joint

Exp. loop other

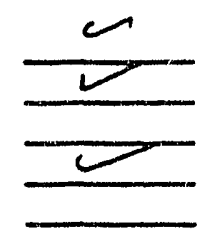

5. Intervals between expansion devices 500-100 feet

6. Condensate return? yes no For $20 \%$ of system

7. Intervals between manholes 300-youfeet

$$
1 / 26 / 0 c h
$$

8. Temperature and pressure $\frac{500}{360} \mathrm{~F} \frac{250}{15} \mathrm{psi}$ (HP steam)

psi (hot water)

B. Current Leak Detection

1. What types/locations of leaks are your biggest problem?

Valves

Welds

Expansion devices

other fritizys

Coucinace tine

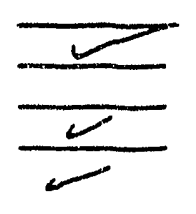

Rollers

Flanges

External corrosion

Condangte lin vacuum system is averuortear

the to lats.

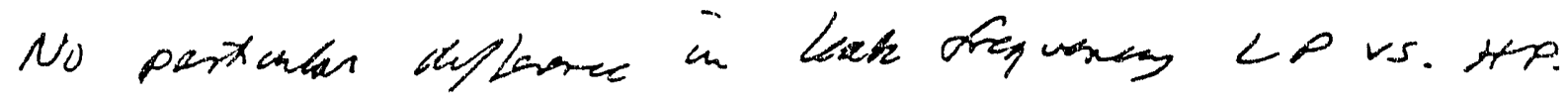


2. How are leaks detected now?

- Cant mainotai vacurm on condenete line

- On conduit installative, put presoure on candersate line, tho leale runs into mantoles

3. How are leaks located?

- Dried "Geophonos" from water ulling ("stethascope on pavoneno") unsucceot tills.

- For soterm leaks, feel pevernos or wathe dor stecm in wace

- Hare IR senoir whire works well except in condvit installa

4. What is the accuracy of your location methods?

\section{c. Use of Acoustic System}

1. Would you be interested in uising an acoustic syster as described earlier? yes no

2. If not, why not?

- Hovert had leaks in 2 yeass

- Borrowed Satiles oquipuat - maste by Dr. Michacel inerked very well. bed plans to buy one.

3. What would increase this system's usefulness to you?

4. Are you interested in:

a. ongoing system for monitoring, detection and location

b. A system for use as necessary to locate leaks detected through other means

5. Would you be interested in field testing a prototype system? yes no 
LEAX DETECTION BURVEY

Name of System Fairbenes Municipal LSY

Contact Name Joht Poul ston ben

Phone

$$
907-459-6259
$$

\section{A. Distribution System}

1. Year oldest pipe installed

2. Miles of pipe

3. Type of pipe installation

4. Expansion devices

Box conduit solid pour conduit Tunnel Prefab conduit Direct Burial other

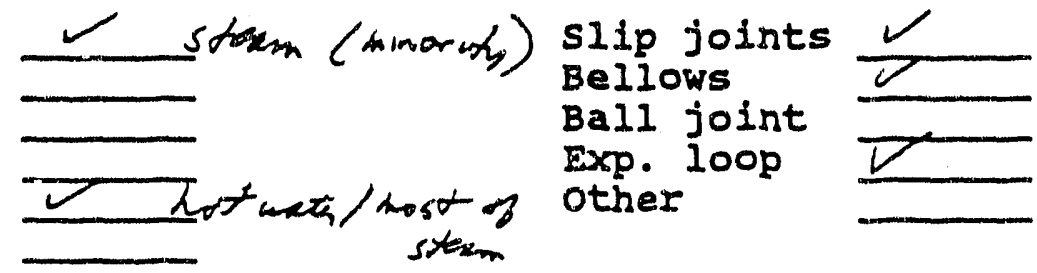

$$
4-6 \cdot \operatorname{dg} \alpha
$$

5. Intervals between expansion devices feet

6. Condensate return? yes no

7. Intervals between manholes feet

0. Temperature and pressure

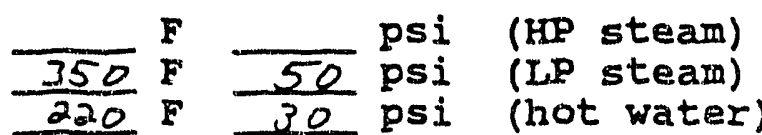

\section{B. current leak Detection}

1. What types/locations of leaks are your biggest problem?

Valves

Welds

Expansion devices other

Cako anát a problan. big ptobiem.
Rollers

Flanges

External corrosion 
2. How are leaks detected now?

$$
\begin{aligned}
& \text { fot wats - wate up wate reguroums } \\
& \text { steen - visible stexm or snow meto. }
\end{aligned}
$$

3. How axe leaks located?

$$
\text { snow nectelgrous hat }
$$

4. What is the accuracy of your location methods?

\section{Use of Acoustic System}

1. Would you be interested in using an acgristic system as described earlier? yes 12 no

2. If not, why not?

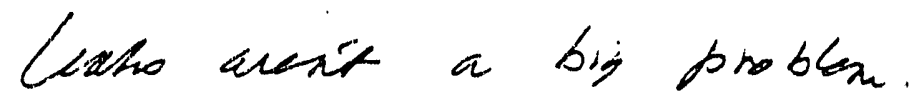

3. What would increase this system's usefulness to you?

4. Are you interested in:

a. ongoing system for monitoring, detection and location

b. A system for use as necessary to locate leaks detected through other means

5. Would you be interested in field testing a prototype system? yes no 
IEAT DETECTION BURVEX

Name of System

Geopia Prun

Contact Name

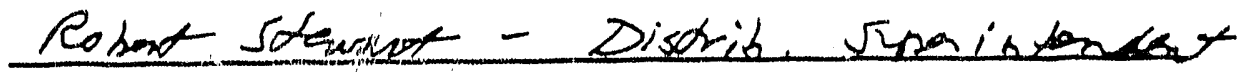

Phone $404-3^{2} 4-46>8$

\section{A. Distribution system}

1. Year oldest pipe installed

1907

2. Miles of pipe $25-30$

3. Type of pipe installation

4. Exparsion devicac

Box conduit solid pour conduit Tunnel pxefab conduit Direct Burial other

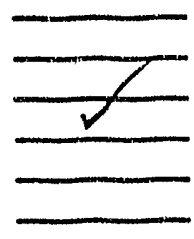

slip jointa Bellows Ball joint Exp. loop other

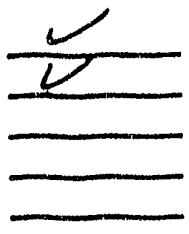

5. Intervals between expansion devices $100+$ feet

6. Condensate return? yes no

7. Intervals between manholes

feet Usually wherenes thasó a joinor. No ser intoural.

8. Temperature and pressure

$$
\begin{array}{rll}
330 \mathrm{~F} & 90 \text { psi } & \text { (HP steas) } \\
-240 \mathrm{~F} & 10 \text { psi (LP steam) } \\
\hline
\end{array}
$$

B. Current reak Detection

1. What types/locations of leaks are your biggest problem?

$$
\begin{aligned}
& \text { Valves } \\
& \text { Welds } \\
& \text { Expansion devices } \\
& \text { other } \\
& \text { No purowen patten }
\end{aligned}
$$$$
\text { Rollers }
$$$$
\text { Flanges }
$$$$
\text { External corrosion }
$$ 
84

2. How are leaks detected now?

Vapor in manhole.

3. How are leaks located?

Dig!

4. What is the accuracy of your location methods?

c. Use of Acoustic system

1. Would you be interested in using ar acoustic system as described ear li ier? yes no

2. If not, why riot?

"Baster on expenarses, nothing works."

3. What would increase this system's usefulness to you?

4. Are you interested in:

a. ongoing system for monitoring, detection and location

b. A system for use as necessary to locate leaks detected through other means

5. Would you be interested in field testing a prototype system?

yes

no

cums \leaksurv 
IEAT DETECTION SURVEY

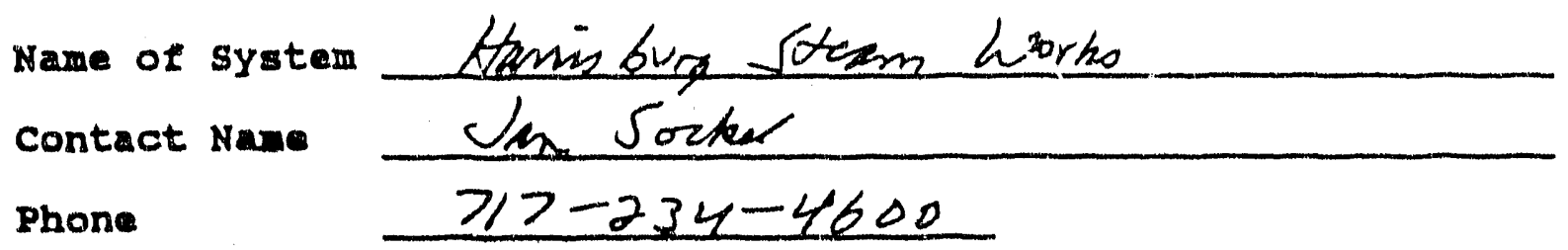

A. Distribution system

1. Year oldest pipe installed

2. Miles of pipe

3. Type of pipe installation

4. Expansion devices

Box conduit solid pour conduit Tunne?

Prefaib conduit

Direct Burial

other

silp joints Be.llows Ball joint Exp. Ioop other

$$
\begin{aligned}
& \text { Mosoty welater sted (1953 or 106) in a split the } \\
& \text { Sone chisestory. } \\
& 3-10 \cdot \cos 2
\end{aligned}
$$

5. Intervals between expansion devices $100-200$ feet

6. Condensate return? yes no

7. Intervals between manholes 200 feet

8. Temperature and pressure Qbout 65\% of siean is raduce 30 psi

B. Temperature and pressure

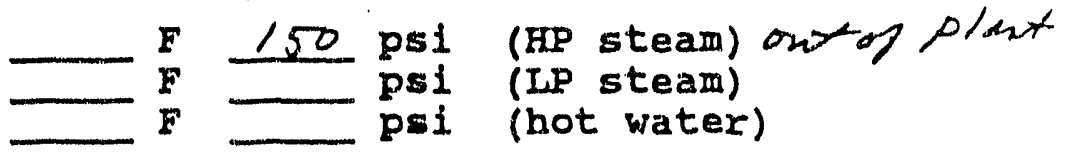

\section{B. Current Leak Detection}

1. What types/locations of leaks are your biggest problem?

Valves

Welds

Exparsion devices other
Rollers

Flanges

External corrosion

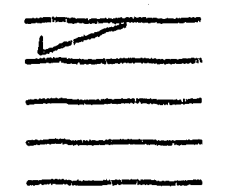


2. How are leaks detected now? Hbransi meserring clevice invente by Dr. Part Michat 'y Pann voda Cniv. $\left(814-238-8533^{\circ}\right.$

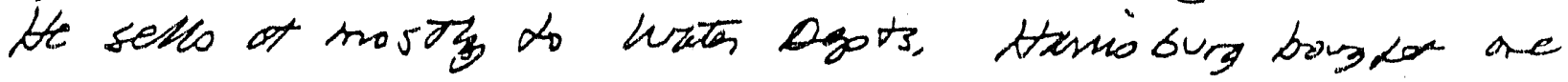

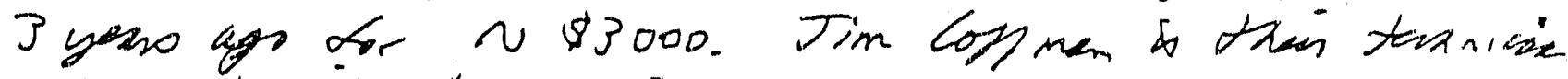
who works with the device Works great but reass a quiet beckproinal. (use in midate of righe). Soted oripod3. How are leaks located? sosen pluemant.

4. What is the accuracy of your location methods? Food.

\section{c. Use of Acoustic System}

1. Would you be interested in using an acoybtic system as desc: ibed earlier? yels

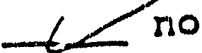

2. If not, why not?

3. What would increase this system's usefulness to you?

4. Are you interested in:

a. Ongoing system for monitoring, detection and location

b. A system for use as necesisary to locate leaks detected through other means

5. Would you be interested in field testing a prototype system? yes no 
IEAT DETECTION BURVEY

Name of system Indieapoeles Pom \& izes

Contact Name

Phone

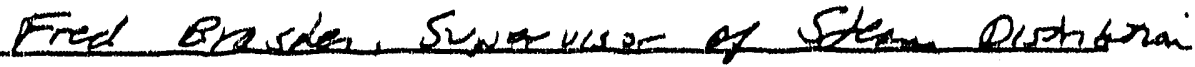
$317-261-8854$

A. Distribution System

1. Year oldest pipe installed

2. Miles of pipe

3. Type of pipe installation

4. Expansion devices

Box conduit Solid pove conduit Tunnel

Prefab conduit

Direct Burial

other

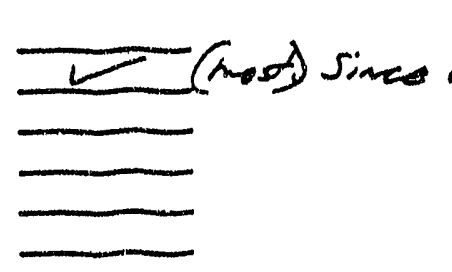

silp joints

1162 Bellows

Ball joint

Exp. 100p

other

$2-10^{\prime}$ depth. Soters pipe

5. Intervals between expansion devices lov-300feet usualls in mantotes

6. Condensate return? yes no

7. Intervals between manholes $100-7$ vo feet

800 mantoles à system

8. Temperature and pressure y00 F 250 psi (HP steam) $270-250 \mathrm{~F}$ 10-15 psi (LP staam)

F psi (hot water)

B. Current Leak Detection

1. What types/locations of leaks are your blggest problem?

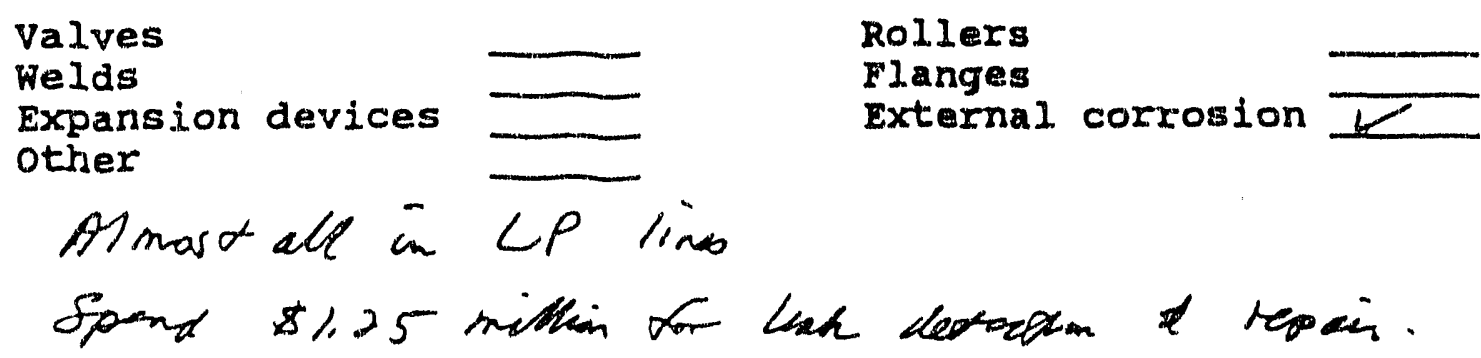


2. How are leaks detected now?

Visible stiren.

3. How are leaks located?

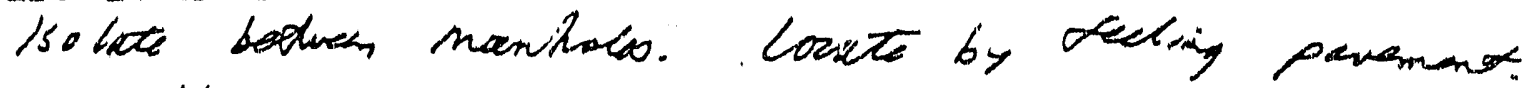
Tried blapt cousosic sysotion 3-4 yaso apo-didiof wark.

4. What is the accuracy of your location methods? "Preto goud".

c. Use of Acoustic system

1. Would you be interested in using an acoustic system as described earlier? yes no

2. If not, why notz bot tipps to problom w/ LP / Imo,

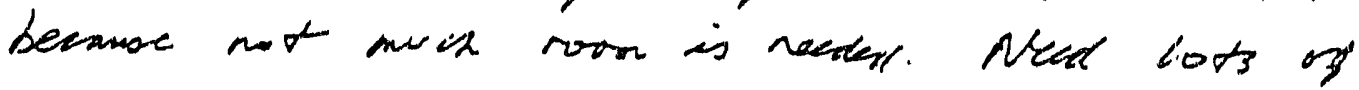
hoom th do thp on Ho systesn.

3. What would increase this system's usefulness to you?

4. Are you interested in:

a. ongoing system for monitoring, detection and location

b. A system for use as necessary to locate leaks detected through other means

5. Would you be interested in field testing a prototype system? $\mathcal{U}$ yes no 
IRAT DETECTIOX GURVEY

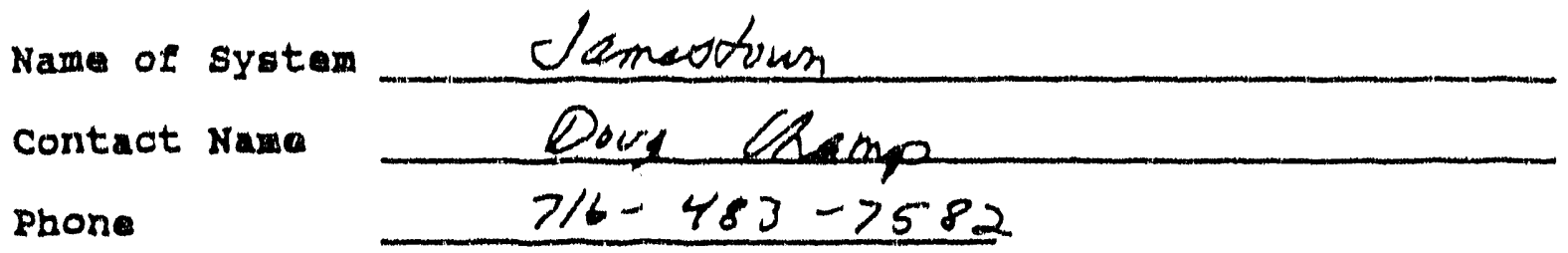

A. Distribution systern

1. Year oldest pipe installed 1984 2. Miles of pipe $\zeta$

3. Type of pipe installation 4. Expansion devicas

Box conduit

solid pour conduit

Tunnel.

prefab conduit

Direct Burlal

othar

Silp joints

Bellows

Ball joint

Exp. Ioop

other

Birtial Aping (1484) Es Ppe. Problom w) strinh stemes.

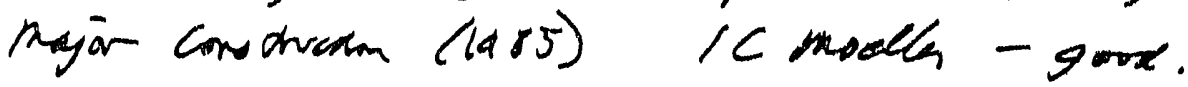

12 - be lageos pioses.

5. Intervals between expansion devices ___ feet

6. Condensate return? __ yes no

7. Intervais betwaen manholes ___ ceet

8. Temporature and preasure $\frac{F}{F}-\begin{aligned} & \text { Psi (HP steam) } \\ & \text { psi (LP steam) }\end{aligned}$

\section{B. Current Lak Detection}

1. What types/locations of leaks are your biggest problem?

Valves

Welds

Expansion devices

other
Rollers

Flanges

External corrosion 
2. How are leaks detected now?

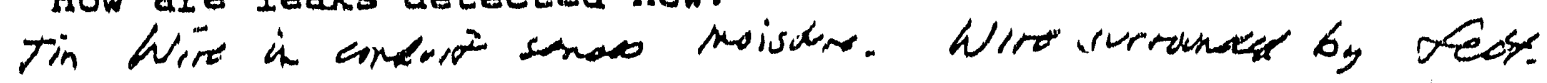

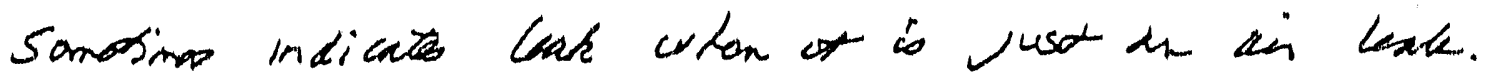
Controm wi matec -up wats.

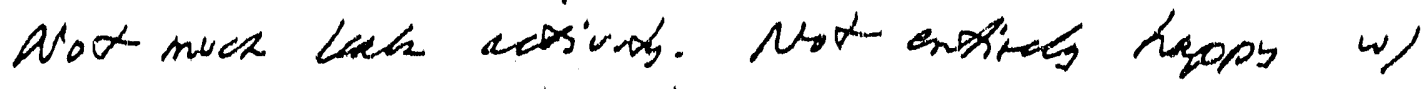
lente doicosai systom.

3. How are leaks located?

4. What is the accuracy of your location methods?

c. Use of Acoustic system

1. Would you be interested in using an acolistic system as described earlier? yes no

2. If not, why not?

3. What would increase this system's usefulness to you?

4. Are you interested in:

a. ongoing system for monitoring, detection and location

b. A system for use as necessary to locate leaks detectad through other means

5. Would you be interested in field testing a prototype system?

_ yes no no 
91

LEAK DETECTION SURVEY

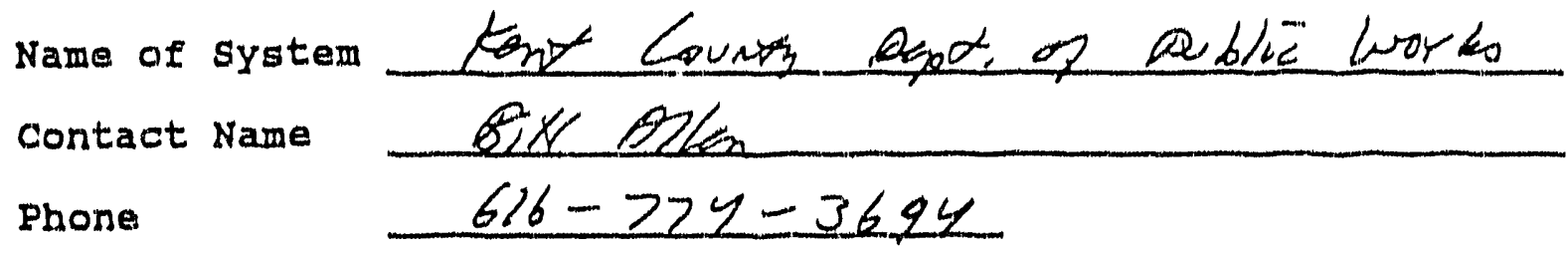

A. Distribution system

1. Year oldest pipe installed 19205

2. Miles of pipe $1 / 2$

3. Type of pipe installation

4. Expansion devices

Brick or blunt BOX conduit solid pour conduit Tunnel

Prefab conduit Direct Burial other sip joints Bellows Ball joint Exp. loop other

Mostly soled. Some ob le coot iron.

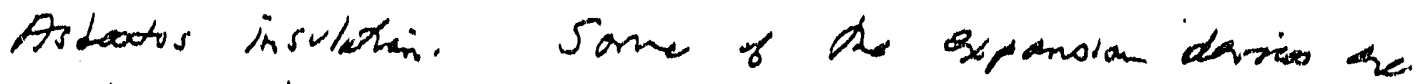
divan burg.

5. Intervals between expansion devices 300-60ig feet vamp

6. Condensate return? yes no

7. Intervals between manholes 500-600 feet ratio 18 manholes

8. Temperature and pressure 352-366 F 125-150 psi (HP steam)

$22 \pi 250 \mathrm{~F} 5-15$ psi (IP steam) F psi (hot water)

B. Current Leak Detection

1. What types/locations of leaks are your biggest problem?

Valves

Welds

Expansion devices other
Rollers

Flanges

External corrosion

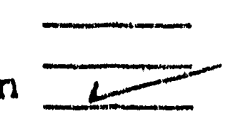

Portions of LP system shut down during sumatra.

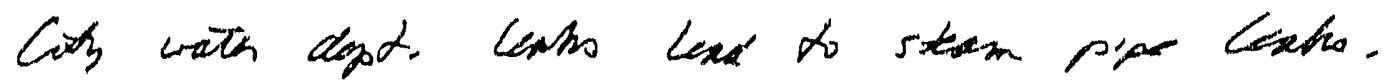


2. How are leaks detected now?

$$
\begin{aligned}
& \text { - Compolaños } \\
& \text { - Rrora-Red } \\
& \text { - Map } x \text { line Meinotance } \\
& \text { - Fuepsucos raxio }
\end{aligned}
$$

3. How are leaks located?

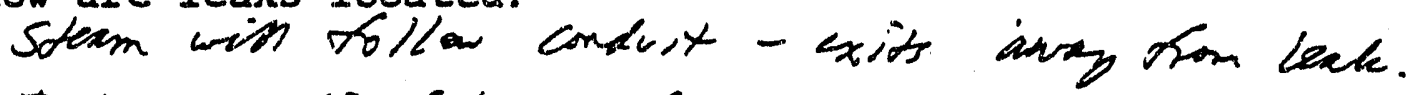

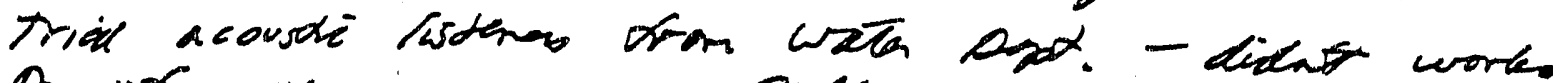

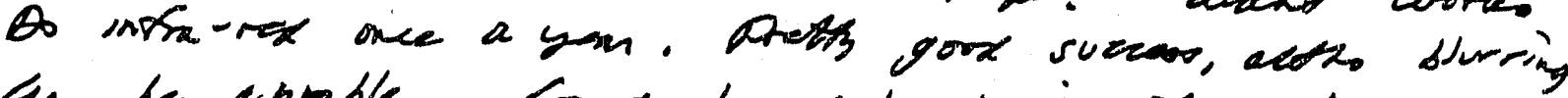

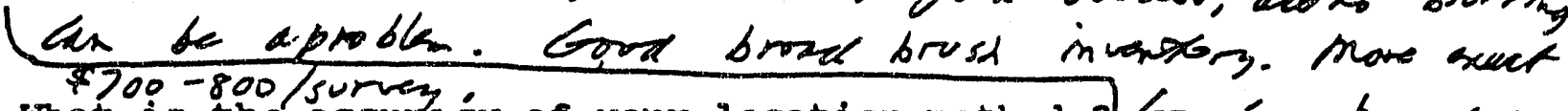

4. What is the accuraćy of your location methods? losation b cod on feching p proment a revew of arewngs.

c. Use of Acoustic system

1. Would you be interested in using an acoustic system as described earlier? yes no

2. If not, why not?

Quich sorvic: podotarom is bes.

Hit the same tive, wot exciois about lat tyos.

3. What would ixcrease this system's usefulness to you?

No hot thp

4. Are you interested in:

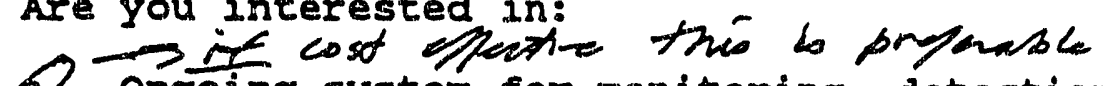

ah ongoing system for monitoring, detection and location

b. A system for use as necessary to locate leaks detected through other means

5. Would you be interested in field testing a prototype system?

yes no 
IEAR DETECTION BURVEY

Name of system

Minneapolis Encon Cents

Contact Name

Gon Goutation

Phone

$612-349-60>2$

\section{A. Distribution system}

1. Year oldest pipe installed

2. Miles of pipe

3. Type of pipe installation

4. Expansion devices

Box conduit

solid pour conduit

Tunnel

Prefab conduit

Direct Burial

other

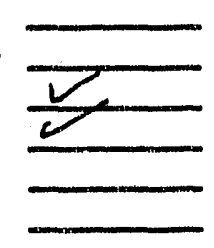

slip joints

Bellows

Ball joint

Exp. Ioop

other

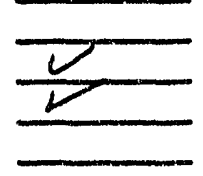

hecder sout or sotem is cheller wats.

5. Intervals between expansion devices $300-40$ ofeet

6. Condensate return?

yes no

7. Intervals betwean manholes $300-400$ reet Sometind on bod sides or inderocetion

8. Temperature and pressure 406 F 250 psi (hP steam) 365 F 150 psi (LP steam) $\rightarrow 1 / 4-1 / 3$ of psi (hot water) system

B. Current Leak Detection

1. What types/locations of leaks are your biggest problem?

Values

WeIds

Expans:ion devices

other condenoato

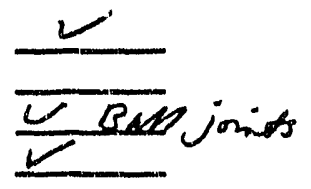

Rollers

Flanges

External corrosion

Not nurch of a problon. Wruedly conderoate line 
2. How are leaks detected now?

Visible sotean

3. How are leaks located?

$$
\begin{aligned}
& \text { Oig, brex on sitration. } \\
& \text { only } 2-3 \text { tives. }
\end{aligned}
$$

4. What is the accuracy of your location methods? OK, hot muen expesince.

c. Use of Acoustic system

1. Would you be interested in using an acoustic system as described earlier? yes no

2. If not, why not?

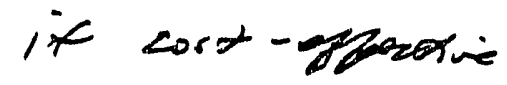

Fees hoot tap conld be dore in rentote it lole is small.

3. What would increase this system's usefulness to you? Be able to hin a ingheor who owns

4. Are you interestedin: rethes than bus iot,

a. Ongoing system for monitoring, detection and location b. A system for use as necessary to locate leaks detected through other means

5. Would you be interested in field testing a prototype system? yes no 
95

IEAR DETECYION BURVEY

Name of System

Contact Name

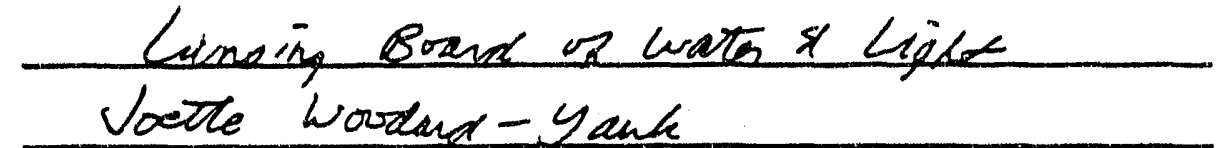

Phone

$5 / 7-3>1-6780$

\section{A. Distribution System}

1. Year oldest pipe installed 1908

2. Miles of pipe

3. Type of pipe installation

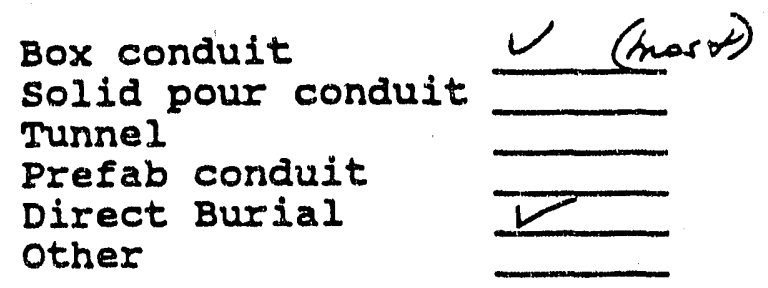

4. Expansion devices

sifp joints Bellows

Ball joint Exp. loop other

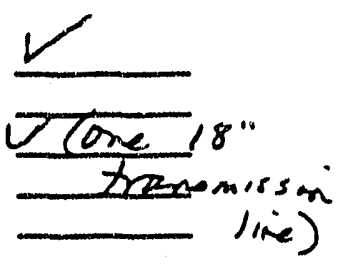

$$
\begin{aligned}
& \text { Mosts wexes cabon stear. Originat pipar ow }
\end{aligned}
$$

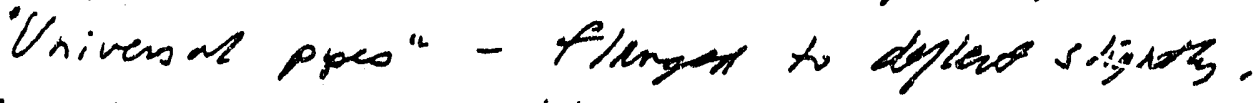

$$
\begin{aligned}
& \text { Abo } a_{p} \text { la pips - to pipo uside Lp'pipe. (n/42y) } \\
& \text { Rolecing Dyplex are Virivest pioe. }
\end{aligned}
$$

5. Intervals between expansion devices 400 feet mas $\sigma$ commenh

6. Condensate return? Yes no

7. Intervals between manholes 20u-juofeet

8. Temperature and pressure $4 / 0 \mathrm{~F} \quad 265 \mathrm{psi}$ (HP steam) $325 \mathrm{~F}-80$ psi (IR steam) $225-250$ F $5=15$ psi (betwatar)

\section{B. Current Leak Detection}

1. What types/locations of leaks are your biggest problem?

Valves

Welds

Expansion devices other
Rollers

Flanges

External corrosion

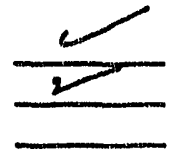


2. How are leaks detected now?

Visible sotam

3. How are leaks located? $\rightarrow$ there used for $\sim /$ san. hand-hele themal mete - hola wast high.

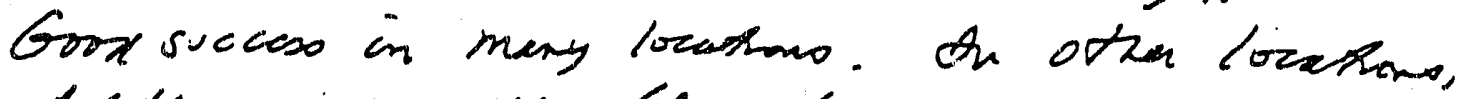

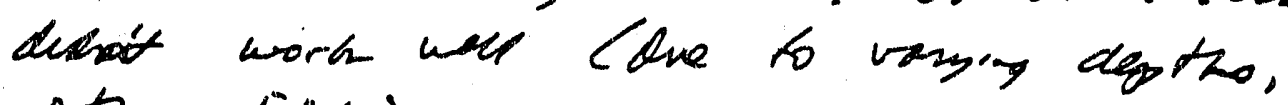

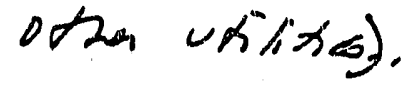

4. What is the accuracy of your location methods?

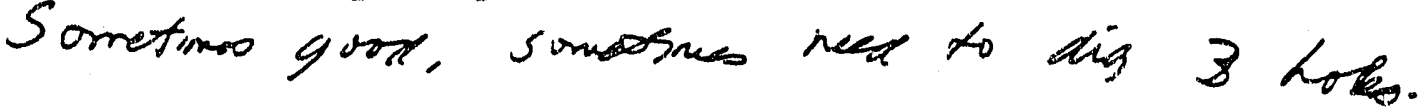

c. Use of Acoustic system

1. Would you be interestei in using an acoustic system as described earlier? yes no

2. If not, why not? pithoush otha problim be cunnow

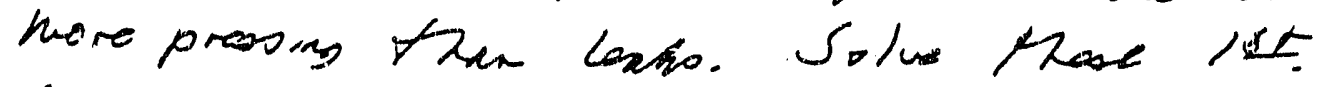
Concen with corrosin potenot at hot tap.

3. What would increase this system's usefulness to you?

4. Are you interested in:

a. Ongoing system for monitoring, detection and location b9) A system for use as necessary to locate leaks detected through other means

5. Would you be interested in field testing a prototype system? Yes no 


\section{LEAX DETECTION BURVEY}

Name of System

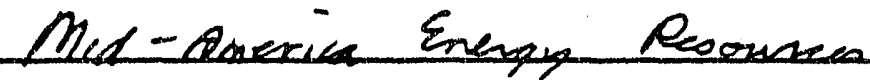
Contact Name David kierel, Psuen Eygaver

Phone $317-261-8893$

A. Distribution system

1. Year oldest pipe installed 1190

3. Type of pipe installation

Box conduit solid pour conduit. Tunnel Prefab conduit Direct Burial Other
2. Miles of pipe

4. Expansion devices slip joints Bellows Ball joint Exp. 100p Other

$$
\begin{aligned}
& \text { Chiller wits system. Ducoste irin pipe, } \\
& \text { uninsulatid. No builotin leak degtexion. } \\
& \text { No cento to vate }
\end{aligned}
$$

5. Intervals between expansion devices feet

6. Condensate return? Yes no

7. Intervals between manholes feet

8. Temperature and pressure

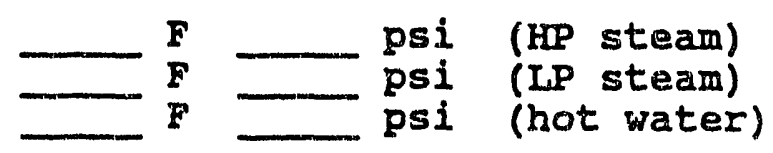

B. Current Leak Detection

1. What types/locations or leaks are your biggest problem?

Valves

Welds

Expansion devices other
Rollers

Flanges

External corrosion 
2. How are leaks detected now?

3. How are leaks located?

4. What is the accuracy of your location methods?

c. Use of Acoustic system

1. Would you be interested in using an acoustic system as described earlier? yes

2. If not, why not?

3. What would increase this system's usefulness to you?

4. Are you interested in:

a. Ongoing syster for monitoring, detection and location

b. A system for use as necessary to locate leaks detecred through other means

5. Would you be interested in field testing a prototype system? yes $\quad$ no 


\section{LEAT DETECTION SURVEY}

Name of System

Neshrite Thormal

Contact Name

Phone

Coga Berh hem

$6 / 5-244-3 / 50$
Serve $3>$ blelgs word stem 1 chillex wats

\section{A. Distribution System}

1. Year oldest pipe installed $\frac{1974}{1186}{ }^{2}$. Miles of pipe

3. Type of pipe installation

Box conduit

Solid pour conduit

Tunnel

Prefab conduit

Direct Burial

other

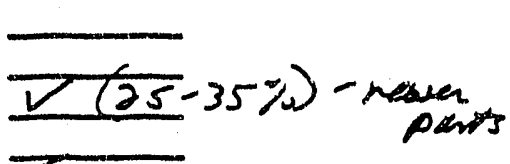

4. Expansion devices

weeded soted - sctam

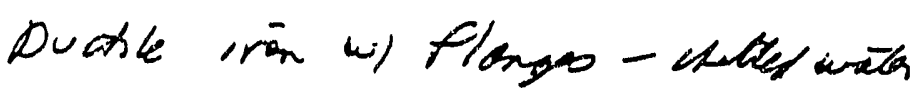

On linootina rook (Anvels)

slip joints

Bellows

Ball joint

Exp. loop

other

13,000 tows bak corling

22 - 150 mibs thair hate hei 4 chilles - sotean durbins drive. Wreste to Enery:

5. Intervals ketween expansion devices 200 feet $\rightarrow$ all $i$ hande

6. Condensate return? yes no or timel

7. Intervals between manholes 200 feet

8. Temperature and pressure $365 \mathrm{~F} 150 \mathrm{psi}$ (HP steam)

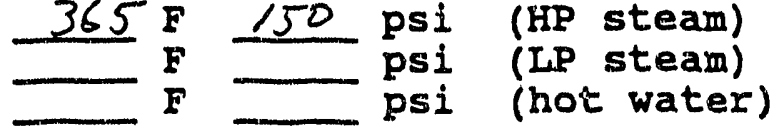

\section{B. Current Leak Detection}

1. What types/locations of leaks are your biggest problem?

Valves

Welds

Expansion devices

other Condons ate
Rollers

Flanges

External corrosion

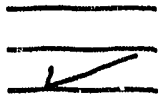

$\rightarrow$ sotare 7 condenoait 
2. How are leaks detected now?

Annual thamographic surves.

3. How are leaks located?

on trund - no problom.

Thenogrzolis phator preth goox.

4. What is the accuracy of your location methods?

c. Use of Acoustic System

1. Would you be interested in using an acoustic system as described earlier? yes no

2. If not, why not?

$$
\text { Ataps with xistis nethore. }
$$

3. What would increase this system's usefulness to you?

4. Are you interested in:

a. Ongoing system for monitoring, detection and location

b. A system for use as necessary to locate leaks detected through other means

5. Would you be interested in field testing a prototype system?

_ yes _ no 


\section{1}

IEAK DETECTION BURVBY

Name of system Pacitic Energy Co./Constal p/ewes Inz Contact Name

Phone

$\frac{\text { Vie Dillowan }}{2 / 3-725-1139}$

A. Distribution System

1. Year oldest pipe installed

3. Type of pipe installation

Box conduit Solid pour conduit Tunnel

Prefab conduit

Direct Burial

other
2. Miles of pipe

4. Expansion devices slip joints Bellows Ball joint Exp. loop Other

hulese cinla soter chelled water pios Asbastos comat sotom pipes Sted hol wath pipis

5. Intervals between expansion devices feet

6. Condensate return? yes no

7. Intervals between manholes feet

8. Temperature and pressure

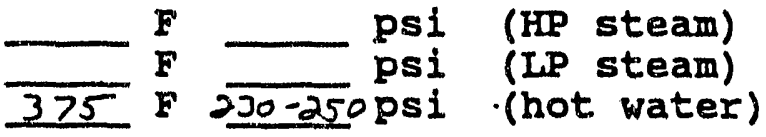

$$
\begin{aligned}
& \text { Also chicter wates }
\end{aligned}
$$

B. Current Leak Detection

1. What types/locations of leaks are your biggest problem?

Valves

Welds

Expansion devices other
Rollers

Flanges

External corrosion

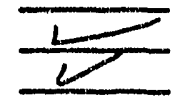


2. How are leaks detected now?

$$
\begin{aligned}
& \text { - Visible socin } \\
& \text { - hake up wata } \\
& \text { - demage do surroundis reotudan }
\end{aligned}
$$

3. How are leaks located? 6 -10 gpm deotion direolota.

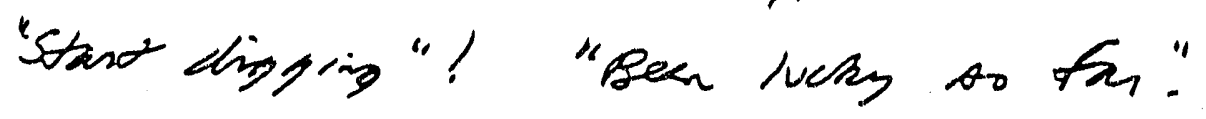

4. What is the accuracy of your location methods?

\section{c. Use of Acoustic system}

1. Would you be interested in tring an acoustic system as described earlier? yes no

2. If not, why not?

3. What would incxease this system's usefulness to you?

4. Are you interested in:

a. ongoing system for monitoring, detection and location 15. A system for use as necessary to locate leaks detected through other means $\rightarrow$ Pnidally. Perhaps. a. th cost-eppartive

5. Would you be interested if field testing a prototype system? no 
103

$8 / 16 / 91$

LEAK DETECTION SURVEY

Name of System

Contact Name

Phone
NR E Themed - Waldort line

Mar prana -

$612-323-5: 25$

A. Distribution System

1. Year oldest pipe installed 1983

3. Type of pipe installation
2. Miles of pipe 5/2

4. Expansion devices Box conduit (cone) $90 \%$ of /n (stan) Solid pour conduit Tunnel

prefab conduit

Direct Burial other

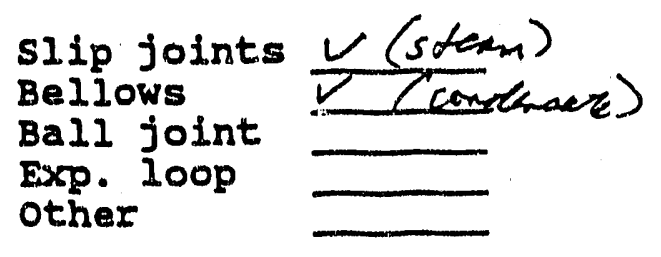

Condensate line w he lest problem. pure conduit w) polsuretaens tram.

Foanuglass on steam line.

8' average dis pin.

5. Intervals between expansion devices 300 feet Arad to sip

6. Condensate return? yes no

7. Intervals between manholes 600 feet

8. Temperature and pressure

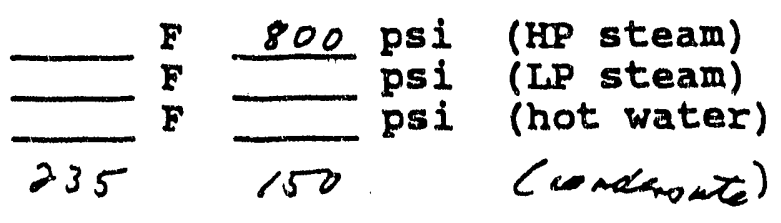

B. Current Leak Detection

1. What types/locations of leaks are your biggest problem?

Valves

Welds

Expansion devices other Condensate
Rollers

Flanges

External corrosion

Usually rear an anchor or vance. 
$\frac{1}{3}$

104

is 's 2. How are leaks detected now? Disugeang barren meters of Trow into $x$ out of the pipe.

Thermel vices diocese work tor them.

3. How are leaks located? Cowl tow vapor ow of vacelf.

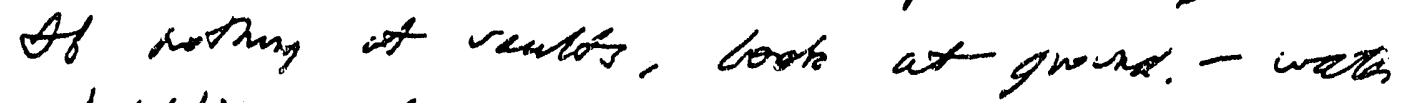
bubbling out.

4. What is the accuracy of your location methods?

Not as good as hid like. Very exposure storing

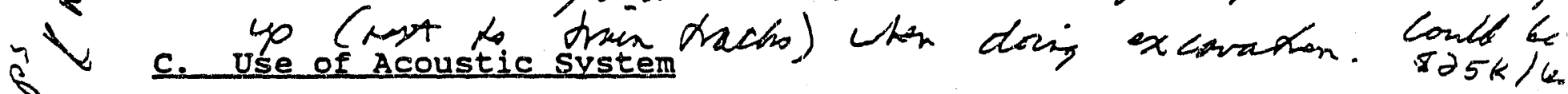

1. Would you be interested in using an acoustic system as described earlier? yes no

2. If not, why not?

$\rightarrow$ Perhaps an eremite system read to be oof up for

londeront

3. What would increase this system's usefulness to you?

Ippluertoro

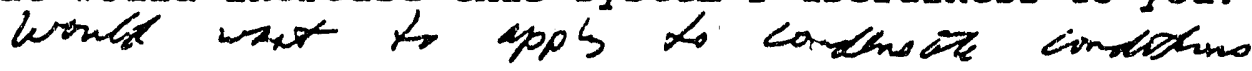

4. Are you interested in:

a. Ongoing system for monitoring, detection and location

6. A system for use as necessary to locate leaks detected

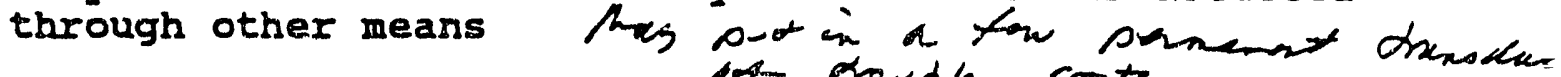

5. Would you be interested in field testing a prototype system?

yes no

Cms\leaksurv 
LEAR DETECTION BURVEY

Name of system Philadeds he Thenec

Contact Name Phone

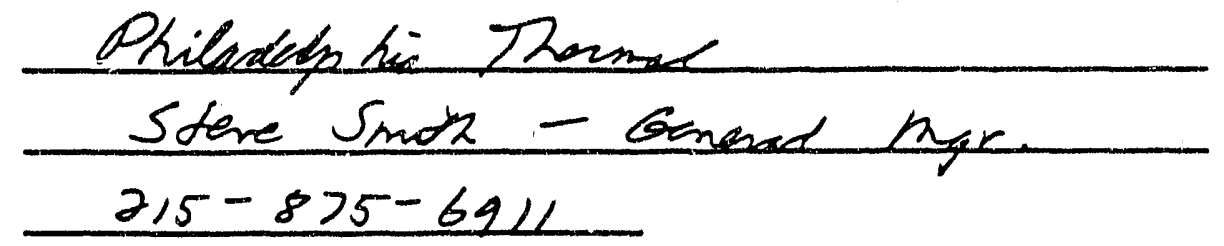

A. Distribution system

1. Year oldest pipe installed

3. Type of pipe installation

Box conduit solid pour conduit Tunnel pup prefat c6nduit Direct Burial other
2. Miles of pipe

4. Expansion devices

slip joints Bellows

Ball joint Exp. loop other

5. Intervals between expansion devices ___ feet

6. Condensate meturn? ___ yes no ___ no

7. Intervals between manholes __ feet

8. Temperature and pressure $\begin{aligned} & 365 \\ & 395 \mathrm{~F} \\ & 225 \mathrm{psi}\end{aligned} \begin{aligned} & 150 \\ & \text { psi steam) }\end{aligned}$

B. Current Leak Detection

1. What types/locations of leaks are your biggest problem?

Valves

Welds

Expansion devices

other

\section{Rollers}

Flanges

External corrosion

Lakes aresit huch of a problem.

$$
\begin{aligned}
& 2 \text { leath in } 3 \text { yass } \\
& \text { 1. Bex weld } \\
& \text { 2. major line rodure } \\
& \begin{array}{l}
\text { Extemal Lorrosia } \\
\text { on pipe lego cold } \\
\text { io yearso }
\end{array}
\end{aligned}
$$


2. How are leaks detected now?

3. How are leaks located?

4. What is the accuracy of your location methods?

c. Use of Acoustic System

1. Would you be interested in using an acoustic system as described earlier? yes no

2. If not, why not?

$$
\text { Carks net a signitionce problun. }
$$

3. What would increase this system's usefulness to you?

4. Are you interested in:

a. Ongoing system for monitoring, detection and location

b. A system for use as necessary to locate leaks detected through other means

5. Would you be interested in field testing a prototype system?

yes _ no 
107

TEAT DETECTION BORVEX

Name of system Pacijui Goo \& Elate - Son Francis e

Contact Name

Phone

Rich may es - maser

$415-973-3828$

A. Distribution system

1. Year oldest pipe installed $19 / 1$

3. Type of pipe installation

Box conduit

Solid pour conduit Tunnel

Prefab conduit

Direct Burial

other

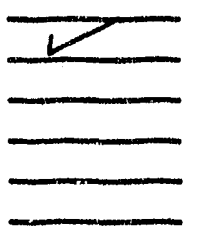

2. Miles of pipe II of main

4. Expansion devices

slip joints

Bellows

Ball joint

Exp. Loop

other

Combination of 5 original systems.

Older pipe has l" annular space arovat poe.

Genandly welded steed.

$A$ ten screwed tithing.

Traps and values in manholes.

5. Intervals between expansion devices

6. Condensate return? yes

7. Intervals between manholes feet ranis.

8. Temperature and pressure $350 \mathrm{~F} \quad 125 \mathrm{psi}$ (HP steam)

psi (LP steam)

psi (hot water)

B. Current Leak Detection

1. What types/locations of leaks are your biggest problem?

Valves

Welds

Expansion devices other
Rollers

Flanges

External corrosion

that. 8-10 leablelyea that require excavation to repair. For a while there was ho wat treativent. As a ravel, there is a groove a the hat ion of the pipe. 
108

2. How are leaks detected now?

- Patrol system

- Visit les tomas

- Complains from other vdikites

Pried infra red - hasid worked well.

3. How are leaks located? Use an ecuestiz sysota (Cont tereanon here - high be that h). A problem it the is a bot of bochgroux howe. Otherwise, works well.

4. What is the accuracy of your location methods?

Lets good.

c. Use of Acoustic System

1. Would you be interested in using an acoustic system as described earlier? yes no

2. If not, why not?

Doit bout to do loo taps.

3. What would increase this system's usefulness to you?

4. Are you interested in:

a. Ongoing system for monitoring, detection and location

b. A system for use as necessary to locate leaks detected through other means

5. Would you be interested in field testing a prototype system?

yes no

cms\leaksurv 
IEAX DETECTION BURVRY

Name of system Pittsburgh (PACT L 1 )

Contact Name

Phone Pob $51210^{\circ}$

$412-642-7445$

\section{A. Distribution system}

1. Year oldest pipe installed 1920 s 2. Miles of pipe $\simeq 7$

3. Type of pipe installation

4. Expansion devices

Box conduit solid pour conduit Tunnel $7^{\prime}$ hish, $5^{\prime}$ aice Prefab conduit Direct Burial other

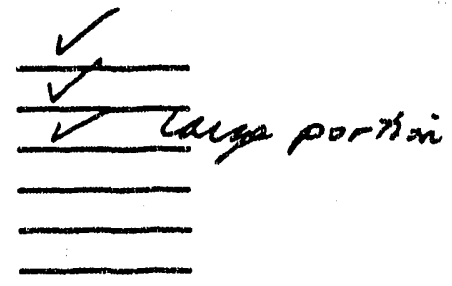

siip joints Beliows Ball joint Exp. Ioop other

$$
\text { wrelded sted }
$$

5. Intervals between expansion devices

feet Uanes

6. Condensate return? yes no

7. Intervals between manholes seet vonis

8. Temperature and pressure plant 150 peri soter.

$$
\text { F }
$$

150 psi (ifp steam) psi (IP steam) psi (hot water)

B. Current Leak Detection

1. What types/locations of leaks are your biggest problem?

Valves

Welds

Expansion devices othex

$\rightarrow$ rpecting win sobp mas $\alpha$ lakes
Rollers

Flanges

External corrosion

Orips

Candensate

Solid pour condrot - ditficult to repain. 
110

2. How are leaks detected now? o X Otherwise, wath/steem in vents,

3. How are leaks located?

- Feer pavement.

- Vapor escaping thru stored.

4. What is the accuracy of your location methods?

Generally good routs

c. Use of Acoustic System

1. Would you be interested in using an acoustic system as described earlier?

2. If not, why not? deprneto on cost.

Concern re cloning hot tap. especially in compost spare.

3. What would increase this system's usefulness to you?

4. Are you interested in:

a: Ongoing system for monitoring, detection and location

0. A system for use as necessary to locate leaks detected through other means

5. Would you be interested in field testing a prototype system?

$\frac{I_{\text {yes }} \text { no Depones on the circus dances, }}{\text { costs, double }}$

cos \leaksurv 
LEAT DETECTION BURVEX

Name of system

Contact Name

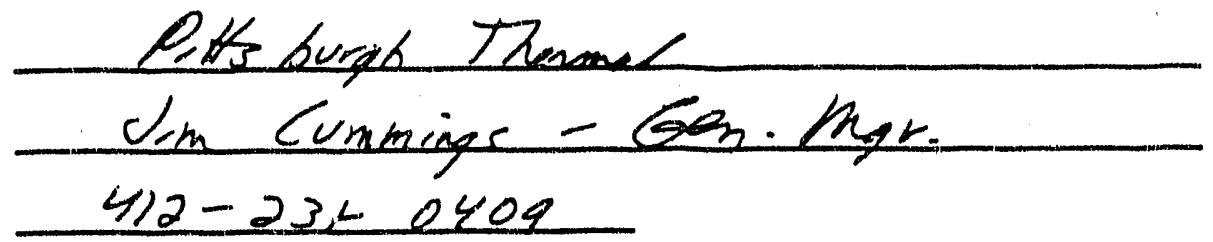

Phone

4) $2-2310409$

a. Distribution system

1. Year oldest pipe installed

2. Miles of pipe

3. Type of pipe installation

4. Expansion devices

Box conduit

solid pour conduit

Tunnel

Prefab conduit

Direct Burial

other

slip joints Bellows Ball joint Exp. loop Other

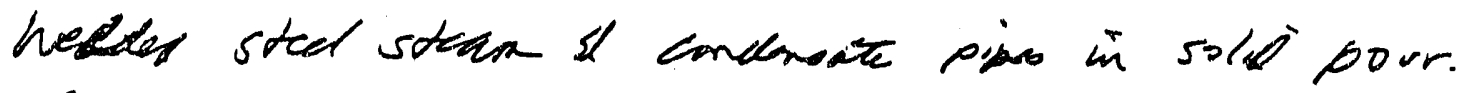
Als. have crille wate sornice.

5. Intervals between expansion devices 100-150 feet

6. Condensate return? yes no

7. Intervals between manholes $100-150$ feet

8. Temperature and pressure $406 \mathrm{~F} 230 \mathrm{psi}$ (HP steam) suhrated psi (LP steam) psi (hot water)

B. Current Leak Detection $150-160 \quad 15-20$ (comensict)

1. What types/locations of leaks are your biggest problem?

Valves

Welds

Expansion devices

other Conatimate

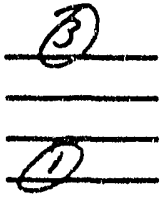

Rollers Flanges External corrosion 
112

2. How are leaks detected now?

- Visible stern or condinacte in wankurte

- Complaint

Condholte lire is the problem.

3. How are leaks located? Tried acoustic controdor sever times,

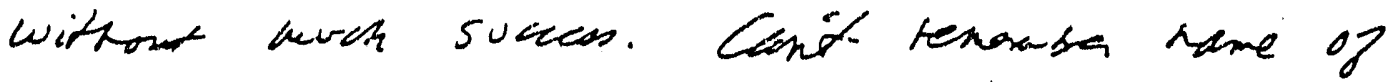

company or type of oquiprat. Generally. stow dying, based on as-buitt Arsing.

4. What is the accuracy of your location methods?

Not ven g good

c. Use of Acoustic system

1. Would you be interested in $\not$ sing an acoustic system as described earlier? U yes no

2. If not, why not?

3. What would increase this system's usefulness to you? oriented to condensate live condenons.

4. Are you interested in:

a. Ongoing system for monitoring, detection and location

7. A system for use as necessary to locate leaks detected through other means

5. Would you be interested in field testing a prototype system?

yes no

cans\leaksurv 
113

LEAR DETECTION SURVEY

Name of system Public Service 6. of Colorado (De ven)

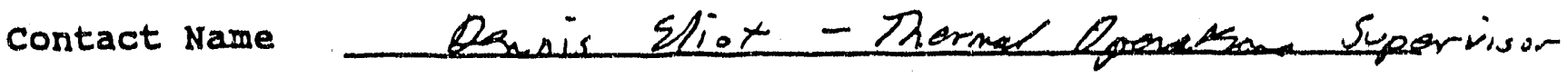
Phone

$$
303-573-4347
$$

A. Distribution System

1. Year oldest pipe installed 1900 's

3. Type of pipe installation

Box conduit

Solid pour conduit Turner

Prefab conduit

Direct Burial

other
2. Miles of pipe $\ell L$

4. Expansion devices

slip joints $\checkmark$ ATS - mast Bellows Ball joint Exp. loop other

welder soled

As) valves, joints are in vaults

5. Intervals between expansion devices

6. Condensate return? yes feet hot sure

7. Intervals between manholes $200-250$ feet $500 \% / 6 / 00 h 2$ valls/block 1 trap per blows

8. Temperature and pressure $350 \mathrm{~F} \quad 125 \mathrm{psi}$ (HP steam)

$260-220$ F $20-30$ psi (LP steam) psi (hot water)

B. Current Leak Detection

1. What types/locations of leaks are your biggest problem?

Valves
Welds
Expansion devices
Other

Rollers

Flanges

External corrosion

Not many leks that are unloader.

has 6 2-3/suman. 
114

2. How are leaks detected now?

Use thermography w/ maid moulds.

peonoly hines a local company who has a ven p

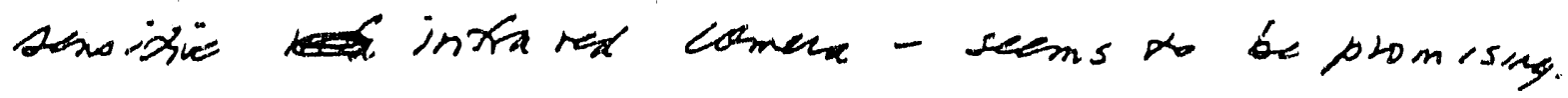

3. How are leaks located?

Narrow down to between 2 vault.

Clear records: di j.

4. What is the accuracy of your location methods?

c. Use of Acoustic System

1. Would you be interested in using an acoustic system as described earlier? yes $<$ no

2. If not, why not? maybe - elevenses an cost ane recessing of hot ip

wont f do hat taps

3. What would increase this system's usefulness to you?

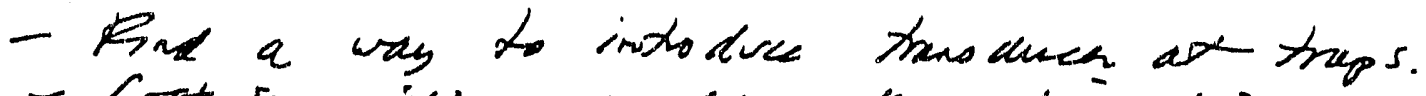

- Cost is an issue - would nat ar his condrackr

4. Are you interested in: who owns wiphol.

a. ongoing system for monitoring, detection and location

b. A system for use as necessary to locate leaks detected through other means

5. Would you be interested in field testing a prototype system?

yes no

Cms\leaksurv 
115

LEX DETECTION SURVEY

Name of system contact Name Phone
Rocheods Distinct tory Comeration Howe Core

$$
7 / 6-546-8890
$$

A. Distribution System

1. Year oddest pipe installed

3. Type of pipe installation

Box conduit comate

Solid pour conduit Tunnel

Prefab conduit

Direct Burial Other

Indewiel Prom $R \in E E$.

weeded stead pipe

प> exp. joints
1880 solder possible

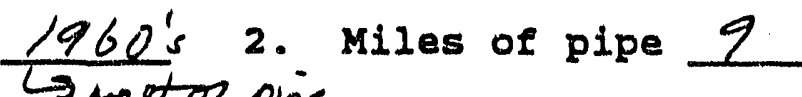

throstof Pipe Expansion devices

slip joints

Bellows

Ball joint

Exp. lop other

260,000 lbs sold

laos you

5. Intervals between expansion devices feet Varies

6. Condensate return? yes no

7. Intervals between manholes feet 86 insenhols

Leaves bovines

8. Temperature and pressure 554

$F$ - psi (LP steam)

$\boldsymbol{F}$

psi

(hot water)

B. Current Leak Detection

1. What types/locations of leaks are your biggest problem?

Valves

Welds

Expansion devices Other
Rollers

Flanges

External corrosion

Fain tight system. Few last.

Ore at a we le and anton at house block. (6 years. Traps ane a bigger problem. 
2. How are leaks detected now?

$$
\begin{aligned}
& \text { Visiols sotram. }
\end{aligned}
$$

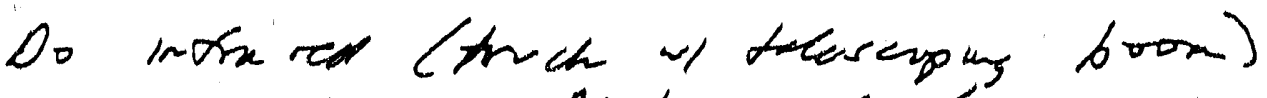

$$
\begin{aligned}
& \text { erey baxi. Not growt Drom by ireans }
\end{aligned}
$$

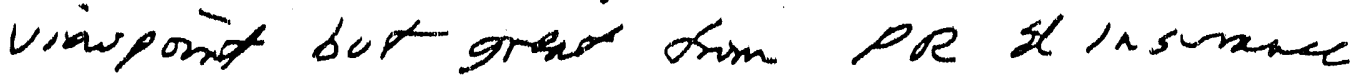

$$
\begin{aligned}
& \text { sotar porist. }
\end{aligned}
$$

3. How are leaks located?

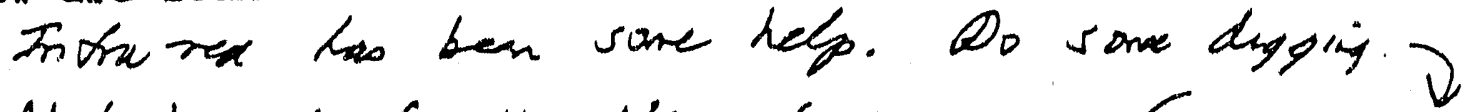

Not hend th the tho sotem Cans.

$(8000 / 2010)$

4. What is the accuracy of your location methods?

\section{c. Use of Acoustic system}

1. Would you be interested in using an acoustic system as described earlier? yes

2. If not, why not?

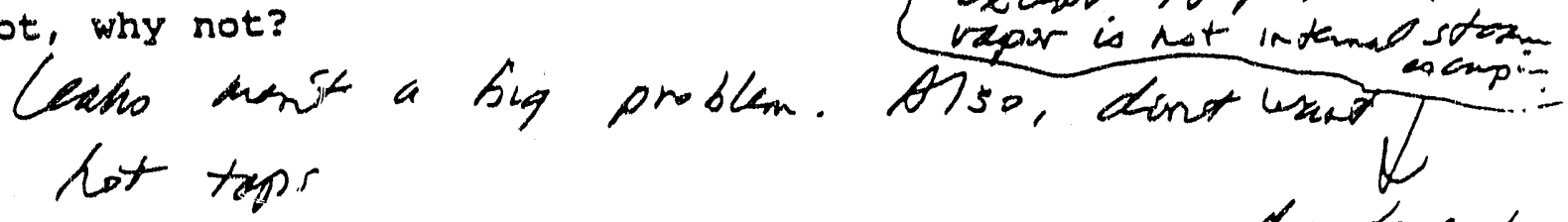

3. What would increase this system's usefulness to you? hruto boiter-

4. Are you interested in:

a. ongoing system for monitoring, detection and location

b. A system for use as necessary to locate leaks detected through other means

5. Would you be interested in field testing a frototype system? $y \in$ no 
LEAX DETECTION GURVEY

Name of system

Contact Name

seote sotem

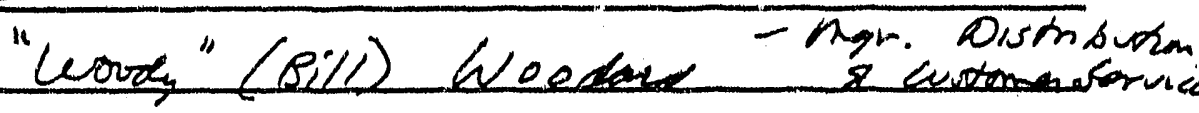

Phone

$206-623-6366$

\section{A. Distribution system}

1. Year oldest pipe installed 1890 s

2. Miles of pipe 18.5

3. Type of pipe installation

4. Expansion devices

Box conduit

solid pour conduit

Tunnel

Prefab conduit

Direct Burial

other

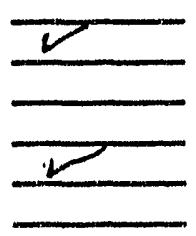

siip joints Bellows

Ball joint

Exp. Ioop

other

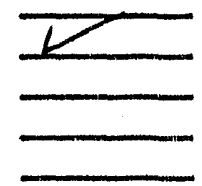

$$
\begin{aligned}
& \text { LP- mag book w redwowa or cexter log } \\
& \text { - rwa - Sram ylas or 2-ineto }
\end{aligned}
$$

Plack Eirtare -

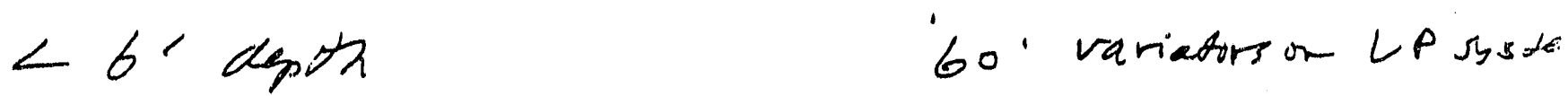

5. Intervals between expansion devices feet

6. Condensate return? yes no

7. Intervals between manholes 300-350 feet hem bloch

8. Temperature and pressure

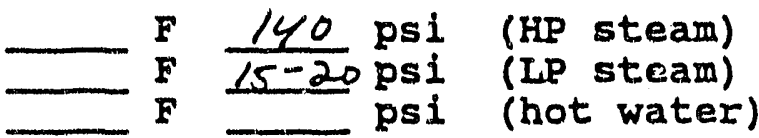

\section{B. Current Leak Detection}

1. What types/locations of leaks are your biggest problem?

Valves

Welds

Expansion devices other
Rollers

Flanges

External corrosion $\square P$ 
Acoustic: - Paul Mucked system (like Hans bu)

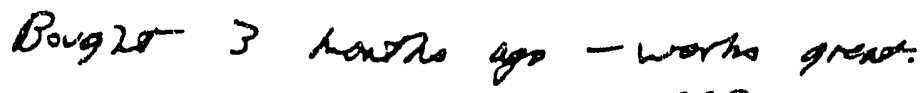

$$
118
$$

$\$ 2600$

2. How are leaks detected now?

Sensor on pavements.

Limitation - tricky w conduct.

he suspects. Work o great

w/ direst buried pipe.

3. How are leaks located?

Many differs types

of soils.

4. What is the accuracy of your location methods?

Haxerat his ser you.

c. Use of Acoustic System

1. Would you be interested in using an acoustic system as described earlier? yes $\_$no

2. If not, why not?

lapp y ar emt system.

3. What would increase this system's usefulness to you?

4. Are you interested in:

a. Ongoing system for monitoring, detection and location

b. A system for use as necessary to locate leaks detected through other means

5. Would you be interested in field testing a prototype system?

yes no

cums \leaksurv 


\section{LEAX DETECTIOY 8ORVEY}

Name of System

Contact Name St. Lowis Ravarel

Phone At Stanze - Director of Opendana $314-621-3550$

\section{A. Distribution System}

1. Year oldest pipe installed

2. Miles of pipe

3. Type of pipe installation

4. Expansion devices

oldh Box conduit

Solid pour conduit Tunnel

New Prefab conduit

Direct Burial

Other

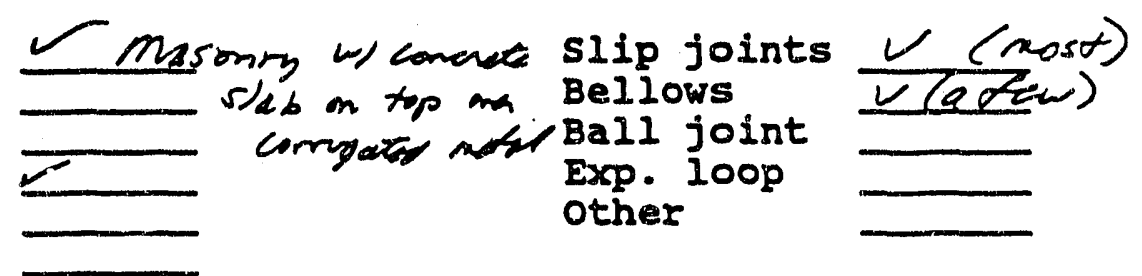

Welded schedule 80 sored

All slips, drips and valwes one in vanlos.

5. Intervals between expansion devices 200 feet

6. Condensate return? yes no

7. Intervals between manholes $\leq 200$ feet

8. Temperature and pressure

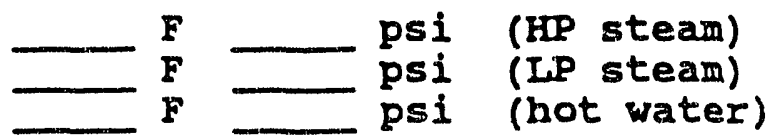

B. Current Leak Detection

1. What types/locations of leaks are your biggest problem?

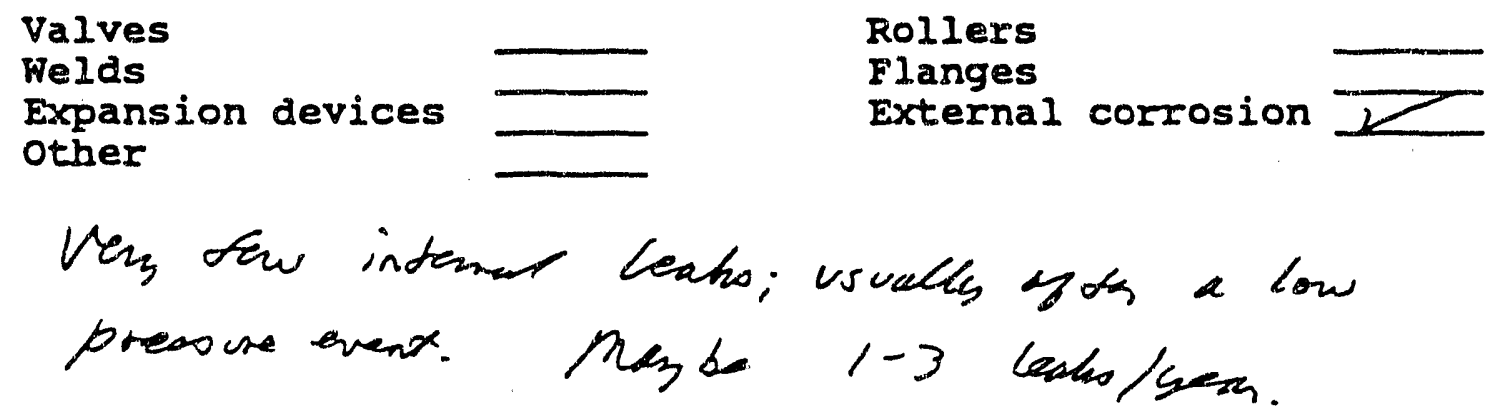


120

2. How are leaks detected now?

Chest each vent on a 6 week notation.

Note hot spots on wall of van at conduit, or

inside steam. Dried Cleveland Dhemalo acosta-

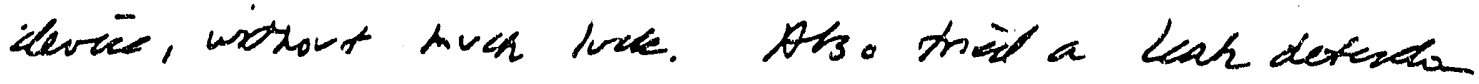

contract (cit roman name).

3. How are leaks located? Faure which rants is hottest. Dr .t/ to

my of conduit i. Listen $x$ look for cockering steam.

Generally at weds. Is do 5 welles per vance.

4. What is the accuracy of your location methods?

c. Use of Acoustic System

1. Would you be interested in using an acoustic system as described earlier? $L$ yes no

2. If not, why not? Although less anent a big problem.

3. What would increase this system's usefulness to you?

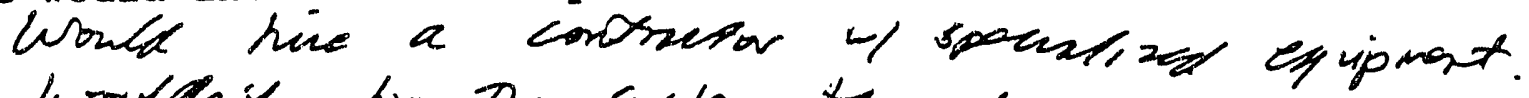
wouldst buy $\lambda$ system thonodmo.

4. Are you interested in:

a. Ongoing system for monitoring, detection and location

6.) A system for use as necessary to locate leaks detected through other means

5. Would you be interested in field testing a prototype system?

L Yes no

cms\leaksurv 
121

LEAK DETECTION SURVEY

Name of system Porous Distort Her en Corp.

Contact Name

Phone

$$
4 / 6-347-6838
$$

A. Distribution System

1. Year oldest pipe installed any 196052 . Miles of pipe $1 / 2$

3. Type of pipe installation

Box conduit

Solid pour conduit Tunnel

Prefab conduit

Direct Burial

other

w/ annular specs

2 billie tits bow
4. Expansion devices slip joints mart t,

Ball joint Exp. loop other

5. Intervals between expansion devices feet raise

6. Condensate return?

$\checkmark$ Yes no in tunes nos

7. Intervals between manholes feet vas

8. Temperature and pressure

250 psi (HP steam)

psi (LP steam)

psi (hot water)

B. Current Leak Detection

1. What types/locations of leaks are your biggest problem?

Valves

Welds

Expansion devices other
Rollers

Flanges

External corrosion

Never had a min line lake.

Biggest problem is Flooding of manhole tram a cos water lea steen boils off the stem line. 
122

2. How are leaks detected now?

- steam in a manhole

- Regular inspector os slip joints (all in venules)

3. How are leaks located?

Tried IR once-workad wed

4. What is the accuracy of your location methods?

C. Use of Acoustic System

1. Would you be interested in using an acoustic system as described earlier? yes $\longleftarrow$ no

2. If not, why not?

- Leaks ar not a problem

3. What would increase this system's usefulness to you?

4. Are you interested in:

a. Ongoing system for monitoring, detection and location

b. A system for use as necessary to locate leaks detected through other means

5. Would you be interested in field testing a prototype system?

yes

no

cr , l leaksurv

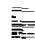


123

LEAK DETECTION SURVEY

Name of system

Contact Name

Phone
Trenton Discreet Eeg, Gro.

Don Leibowitz - Proveloo

$609-396-1842$.

A. Distribution System

1. Year oldest pipe installed 1983

3. Type of pipe installation

Box conduit

solid pour conduit Tunnel

prefab conduit

Direct Burial.

other
2. Miles of pipe

4. Expansion devices

slip joints Bellows

Ball joint Exp. loop other

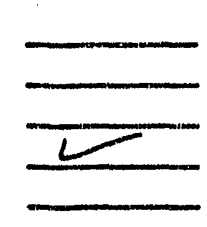

Policing lore we tivenglass.

hrelted sold.

$2-q$ 'depth

5. Intervals between expansion devices

6. Condensate return? yes feet

7. Intervals between manholes $250+$ feet

8. Temperature and pressure

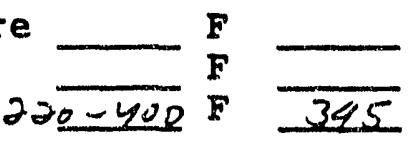
psi (HP steam) psi (LP steam) no 
2. How are leaks detected now?

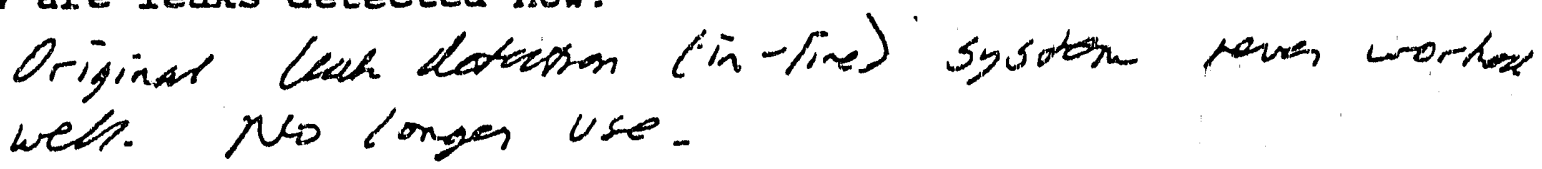

3. How are leaks located?

$$
\text { Touch peremer. }
$$

4. What is the accuracy of your location methods?

c. Use of Acoustic system

1. Would you be interested in using an acoustic system as
described earlier?

2. If not, why not?

3. What would increase this system's usefulness to you?

4. Are you interested in:

a. Ongoing system for monitoring, detection and location

b. A system for use as necessary to locate leaks detected through other means

5. Would you be interested in field testing a prototype system? yes _ no 


\section{LEAX DETECTION BURVBY}

Name of system

Contact Name

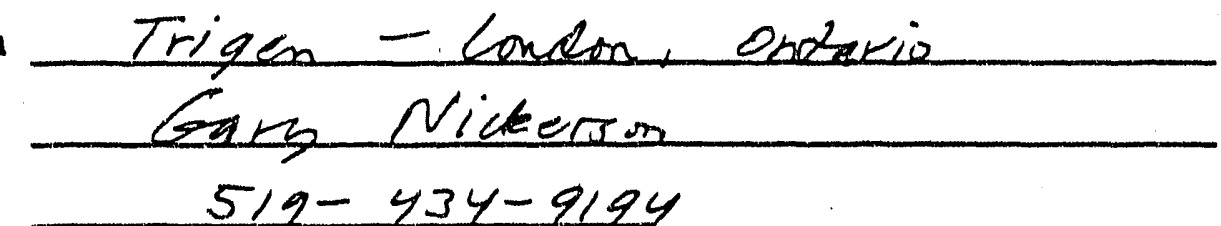

Phone

$$
5 / 9-434-9194
$$

\section{A. Distribution system}

1. Year oldest pipe installed

3. Type of pipe installation

Box conduit

solid pour conduit

Tunnel

Prefab conduit

Direct Burial

other
2. Miles of pipe 4

4. Expansion devices

slip joints Bellows Ball joint Exp. Ioop other

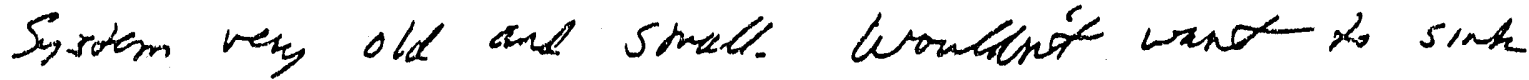

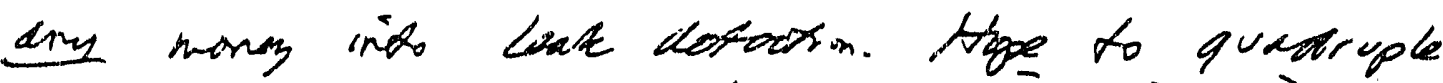
size of sysoter. Would thas puta in in-line losth deotion.

5. Intervals between expansion devices feet

6. Condensate return? yes no

7. Intervals between manholes ceet

8. Temperature and pressure

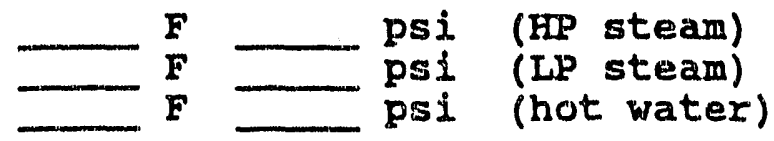

B. Current Leak Detection

1. What types/locations of leaks are your biggest problem?

Valves

Welds

Expansion devices other
Rollers

Flanges

External corrosion 
2. How are leaks detected now?

$$
\begin{aligned}
& \text { - Visible sotexm } \\
& \text { - Dry pot on raing tay }
\end{aligned}
$$

3. How are leaks located?

4. What is the accuracy of your location methods?

c. Use of Acoustic system 1. Would you be interested in using an acoustic system as
described earlier? yes no

2. If not, why not?

3. What would increase this system's usefulness to you?

4. Are you interested in:

a. Ongoing system for monitoring, detection and location

b. A system for use as necessary to locate leaks detected through other means

5. Would you be interested in field testing a prototype system? yes _ no 
LEAT DETECTION BURVEY

Name of system Triga - Enuas Cizg

Contact Name

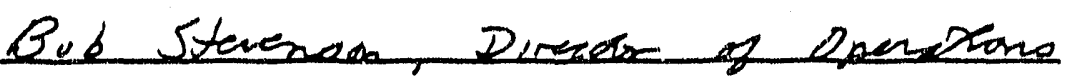

Phone $8 / 6-556-2821$

A. Distribution system

1. Year oldest pipe installed $\sim 1905$ 2. Miles of pipe $q$

3. Type of pipe installation

4. Expansion devices

Box conduit

solid pour conduit

Tunnel

Prefab conduit Direct Burial

Other

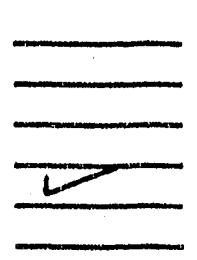

siip joints

Bellows

Ball joint

Exp. loop

Other

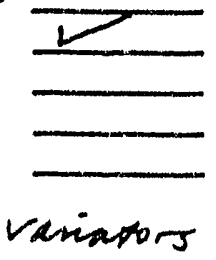

4-10' pipe aloph.

5. Intervals between expansion devices $\angle 100$ feet

5. Condensate return?

Yes

no

7. Intervals between manholes 500-1000feet

8. Temperature and pressure $\frac{380 \mathrm{~F}}{250} \mathrm{~F}-\mathrm{ps}$ (HP steam) $250 F=15$ psi (LP steam)

B. current Leak Detection

1. What types/locations of leaks are your biggest problem?

Valves

Welds

Expansion devices other

LP line do the problem. Din't have mang loxks.
Rollers

Flanges

External corrosion

usuelly at tee, olsow. or vasiator 
2. How are leaks detected now?

$$
\begin{aligned}
& \text { - Visible sotem } \\
& \text { - compoleint }
\end{aligned}
$$

3. How are leaks located?

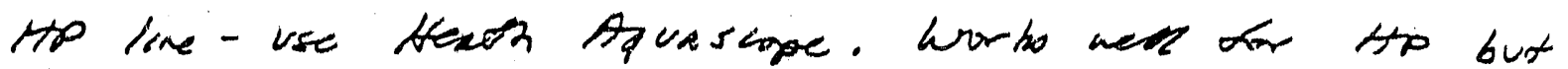
not tor LP. End up haring to dig expluadaz, hotes, erdfor feel the pandinat.

4. What is the accuracy of your location methods?

$$
\text { Good on HP, } 0 k \text { on } \angle P
$$

\section{c. Use of Acoustic system}

1. Would you be interested in using an acoustic system as described earlier? yes no

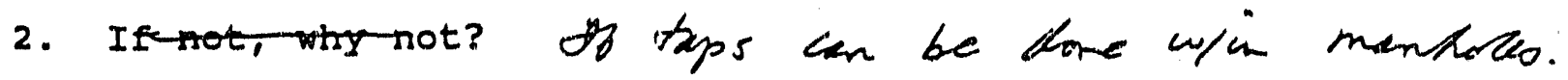

3. What would increase this system's usefulness to you?

4. Are you interested is:

a. Ongoing system for monitoring, detection and location

b. A system for use as necessary to locate leaks detected through other means

5. Would you be interested in field testing a prototype system? yes no "a possibilog" 
LENK DETECTION SURVAX

Name of system Pries

Contact Name

Phone

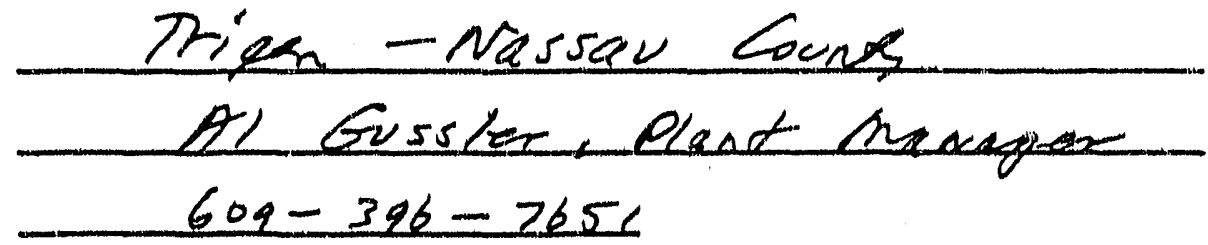

\section{A. Distribution system}

1. Year oldest pipe installed $197 / 2$. Miles of pipe $8-9$

3. Type of pipe installation

4. Expansion devices

Box conduit Solid pour conduit Tunnel

Prefab condult

Direct Burial. other

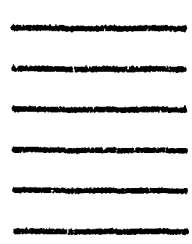

silp joints Bellows

Ball joint Exp. loop other

5. Intervals between expansion devices __ feet:

6. Condensate return? yes no

7. Intervals between manholes feet

8. Temperature and pressure

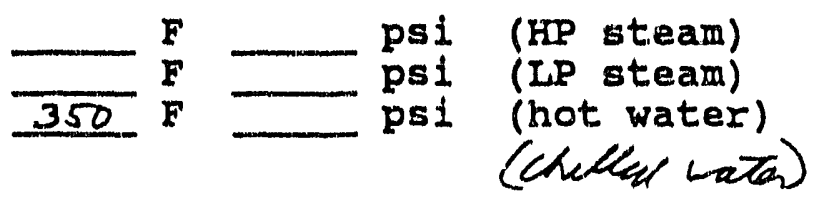

B. Current Leak Detection

1. What types/locations of leaks are your biggest problem?

Valves

Welds

Expansion devices other
Rollers

Flanges

External corrosion

since ruaring the systom ore the last s yexs, hat only I leak. 
2. How are leaks detected now?

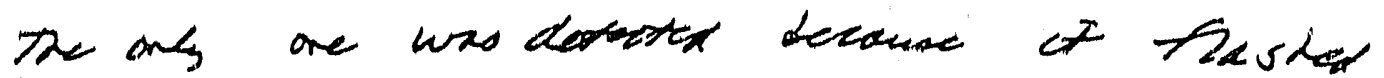

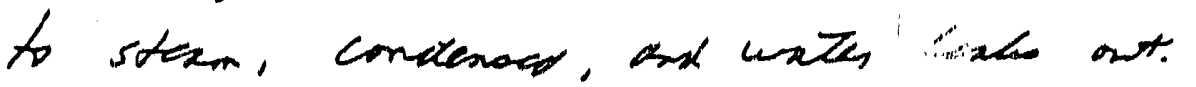

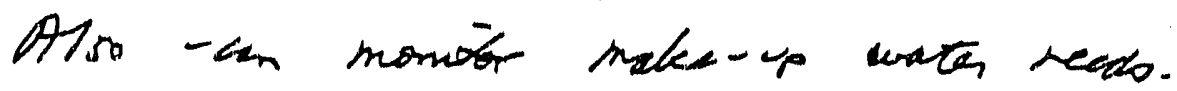

3. How are leaks located?

4. What is the accuracy of your location methods?

$$
\omega / 4 i \quad 5-10 \text {, }
$$

c. Use of Acoustic system 1. Would you be interested in using an gtoustic system as
described earlier?

2. If not, why not?

3. What would increase this system's usefulness to you?

4. Are you interested in:

a. Ongoing system for monitoring, detection and location

b. A system for use as necessary to locate leaks detected through other means

5. Would you be interested in field testing a prototype system?

- yes no no 
131

LEAK DETECTION SURVEY

Name of Systems

Contact Name

Phone
Triage - Tulsa OK

- Dir of Poesatroms

$918-582-2212$

A. Distribution system

1. Year oldest pipe installed 1170

3. Type of pipe Installation

Box conduit

Solid pour conduit

Tunnel

Prefab conduit

Direct Burial

other

2. Miles of pipe 2

4. Expansion devices

Slip joints
Bellows
Ball joint
Exp. loop
other
tex $\&$ uryppr.

conduit w/ insuloorion.

Condensate - Fborglaso Creplating dis is of epoxy-

costed soled)

Cathodic Property on CW due Condensate lis

5. Intervals between expansion devices $\sim 150$ feet aware

6. Condensate return? yes no

7. Intervals between manholes 400 feet avenge - manes 30-12001

8. Temperature and pressure $425 \mathrm{~F} 150 \mathrm{psi}$ (HP steam)

psi (LP steam)

psi (hot water)

B. Current Leak Detection

Cu - souls

$43-54 \quad 110$

Cw - res.

1. What types/locations of leaks are your biggest problem?

Valves

Welds

Expansion devices $\mathbb{V}$ [ aten]

other Conderoat
Rollers

Flanges

External corrosion

$\hookrightarrow$ most leaks

OHs a dew lakes in cur system 
132

2. How are leaks detected now.

Infin -rod- hand held or divive-thro

- corina resosuabls well.

Condropte basho drytuculo to tint

3. How are leaks located?

When the condense line is the ole ribuglass. wills just replace from rankle is manhole roth then th to locate leak.

4. What is the accuracy of your location methods?

C. Use of Acoustic system

1. Would you be interested in lasing an acoustic system as described earlier? yes no

2. If not, why not?

3. What would increase this system's usefulness to you?

4. Are you interested in:

2. Ongoing system for monitoring, detection and location b. A system for use as necessary to locate leaks detected through other means

5. Would you be interested in field testing a prototype system?

_yes _no possibly"

Cms\leaksurv 
Distribution for ANL-92/5

\section{Internal:}

W. E. Brewer

H. Drucker

N. Heeg

D. E. Karvelas

D. S. Kupperman (50)

R. Lanham
W. P. Lawrence

C. A. Malefyt (2)

A. C. Raptis

S. H. Sheen

C. E. Tyll

R. A. Valentin
R. W. Weeks

ANL Patent Dept.

ANL Contract File

TIS Files (3)

\section{External:}

DOE-OSTI, for distribution per UC-350 (331)

ANL Libraries (3)

DOE Chicago Operations Office:

Manager

F. Herbaty

Materials and Components Technology Division Review Committee:

H. Berger, Industrial Quality, Inc., Gaithersburg, MD

M. S. Dresselhaus, Massachusetts Institute of Technology, Cambridge, MA

S. J. Green, Electric Power Research Institute, Palo Alto, CA

R. A. Greenkorn, Purdue University, West Lafayette, IN

C. -Y. Li, Cornell University, Ithaca, NY

P. G. Shewmon, Ohio State University, Columbus

R. E. Smith, Electric Power Research Institute, NDE Ctr., Charlotte, NC

Elaine K. Allen, Green \& Associates, Dallas

Mr. Mark Anderson, NRG Thermal, Minneapolis

Carl E. Avers, Catalyst Thermal Energy Corp., Youngstown, OH

Mark Avers, Baltimore Steam Co., Baltimore

Arturo F. Barcena, Medina, NY

Jeffrey P. Bees, Youngstown Thermal Corp., Youngstown, OH

Leif Bergquist, Trigen Energy Corp., New York

Iver Blackberg, Blackberg Assoc., Arlington Heights, IL

Timothy Block, Detroit Edison Co., Detroit

David Bonkovich, Heath Consultants, Inc., Belle Vernon. PA

James R. Brooks, Baltimore Steam Co., Baltimore

Rudy Brynolfson, St. Paul, Inc, St. Paul

Frederick Callowhill, Exec. Dir., IDHCA, Sanford, NC

John M. Casey, Univ. of Georgia, Athens

Wyndham Clarke, U.S. Dept. of Housing \& Urban Dev., Washington

Lewis C. Cohen, Philadelphia Thermal Corp., Philadelphia

Floyd Collins, DOE, Washington

Robert O. Couch, RPSI, Inc., Brecksville, $\mathrm{OH}$

Mr. M. Danbo, J.C. Hempel's Handelssus A/S, Copenhagen K, Denmark

Glen H. Fukuda, Fukuda Intl., Lafayette, CA 
Jack Gleason, Washington

Bill Goodwin, Harrisburg SW, Ltd., Harrisburg, PA

Gary Gustafson, MEC, Minneapolis

James F. Harley, Intergy, Inc., Brecksville, OH

Gene Hess, Wisconsin Elec. Power Co., Milwaukee

David F. Hobson, IDHCA, Washington

Jay Holmes, USDOE, Washington

Leslie J. Jardine, Bechtel National, Inc., San Francisco

Loraine Kasprzak, Consolidated Edison Co. of New York, Inc., New York

Jack Kattner, MEC, 1060 IDS Center, Minneapolis, MN

P.G. Kemp, GAP Technologies, Menlo Park, 0102, South Africa

Brian Kirk, Consolidated Edison, New York

Y. Kitaura, Sumitomo Chemical America, Inc., New York

John Kuhns, Catalyst Energy Dev. Corp., New York

William Mariutto, KAFA Intl,, Rivera Beach, FL

Richard Mayer, PG\&E Co. San Francisco

Michael E. McKay, Princeton Univ., Princeton

Dr. William Messner, Consolidated Edison R\&D, New York

Anthony C. Mirabella, Energy Networks Inc., Hartford, CT

Michael J. Nagel, Univ. of Minnesota Plant, Minneapolis

E. W. Ng, Consolidated Edison, New York

Hans Nyman, St. Paul, Inc., St. Paul

Yousuf H. Al Omar, United Gulf Construction Co. WLL, Safat. Kuwait

Ishai Oliker, Burns and Roe, Ordell, NJ

Seth J. Perkinson, III, The Perkinson Co., Charlotte, NC

Robert J. Perry, Heath Consultants, Inc., Stoughton, MA

Eugene Peters, 301 N. Amin Ave., Scranton, PA

Sigrid H. Pilgrim, Intercon Research Associates, Ltd., Evanston, IL

Christopher Pioli, Dept. of Utilities-Gas Division, Colorado Springs, CO

Dean Price, Georgetown University, Washington

W.L. Puckering, W.L. Puckering Consulting, Inc., Vancouver, B.C.

Hermine Randall, Univ. of Mass./Amherst, Amherst, MA

Zeph Regnier, 140 Promenade du Portage Phase IV Lv2, Hull, Quebec K1A OM3

Anders Rydaker, District Energy Systems, Roseville, MN

Paul J. Sausville, Bulk Storage Section, Div. of Water, Albany

Roger E. Scholl, URS/John A. Blume \& Associates, San Francisco

Beth Schumake, Neotronics North America, Inc., Gainesville, GA

Mark Spurr, Resource Efficiency, Inc., St. Paul

Darrell D. Stalzer, Iowa EL \& P Co., Cedar Rapids, IA

Fred Strnisa, NY State Energy R\&D Auth., Albany

David W. Wade, Resource Dev. Assoc., Inc., Atlanta, GA

Galen Young, Fisher Research Lab., Los Banos, CA 

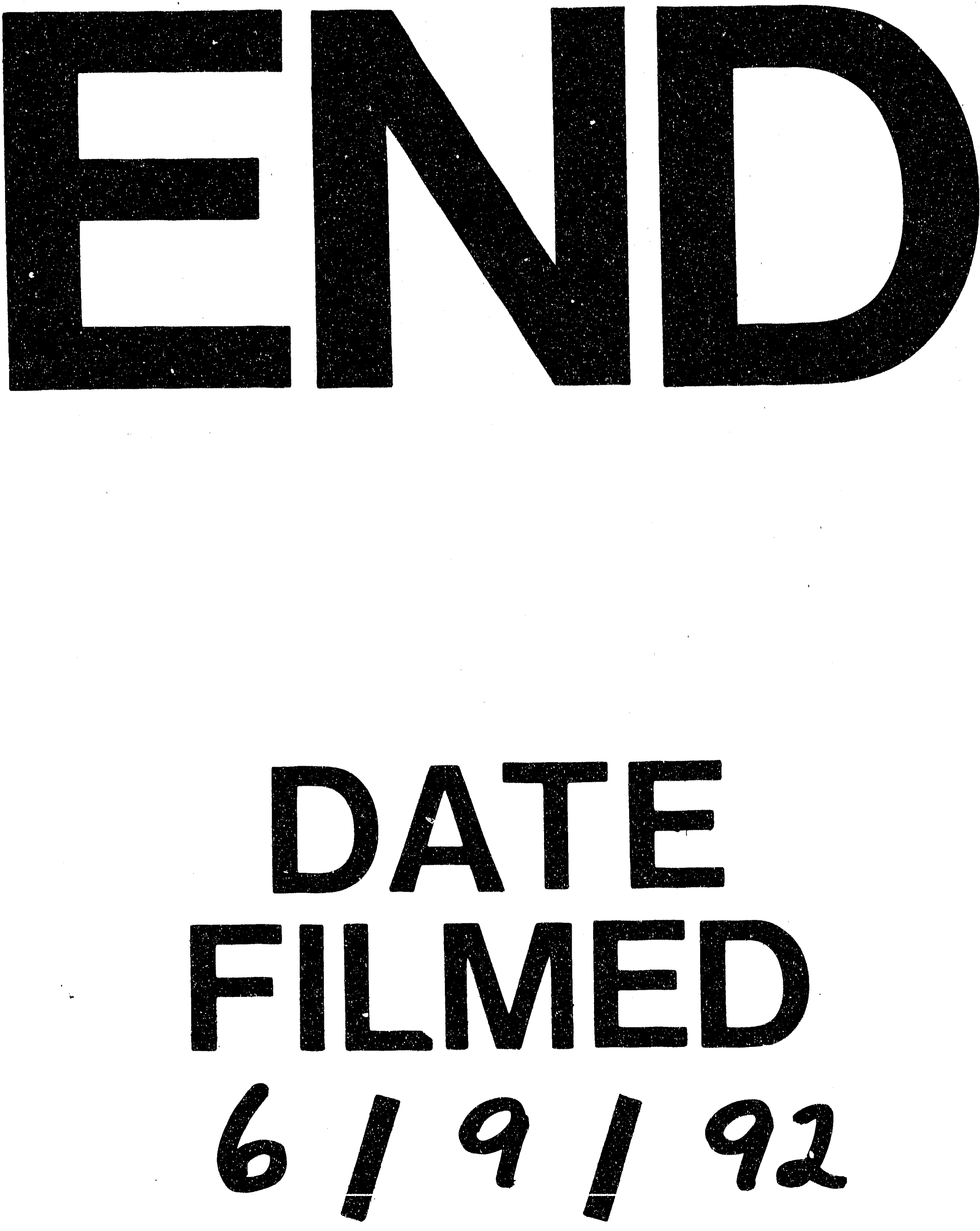
$=$

亚 